UMBERTO G. CORDANI

\title{
EVOLUÇÃO GEOLÓGICA PRÉ-CAMBRIANA DA FAIXA COSTEIRA DO BRASIL, ENTRE SALVADOR E VITÓRIA
}

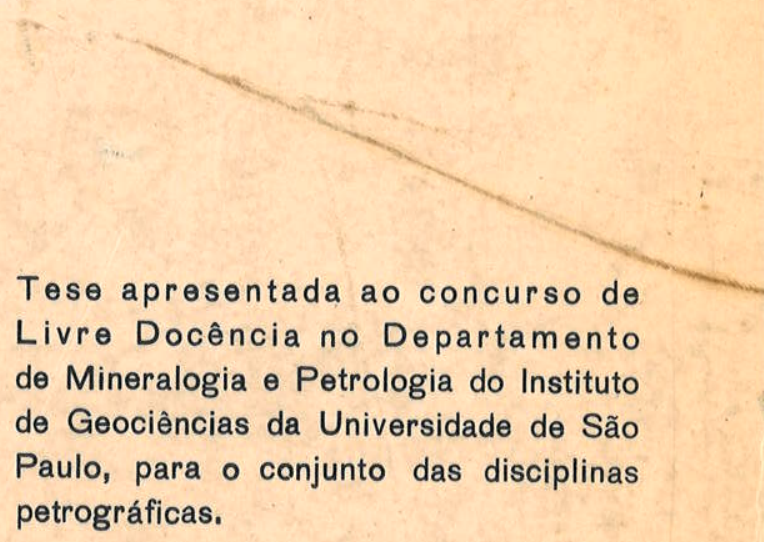




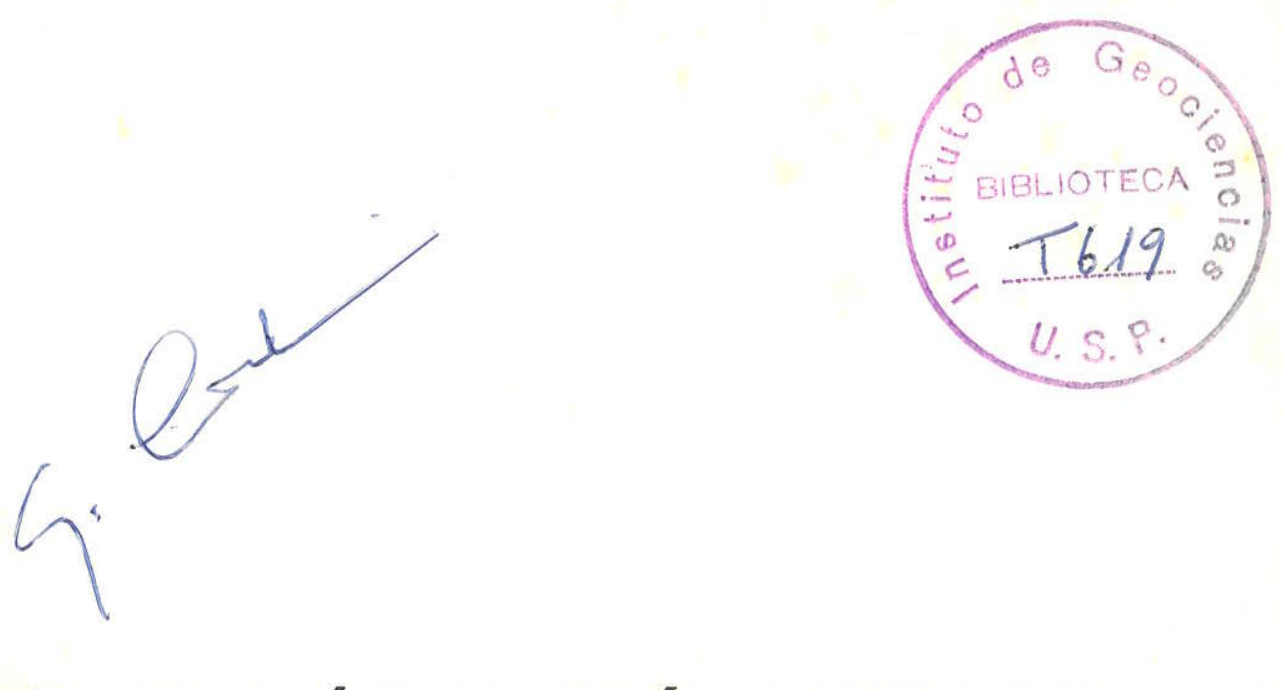

\section{EVQLUUÇÃO GEOLÓGICA PRÉ-CAMBRIANA DA FAIXA COSTEIRA DO BRASIL, ENTRE SALVADOR E VITÓRIA}

Tese apresentada ao concurso de Livre Docência no Departamento de Mineralogia e Petrologia do Instituto de Geociências da Universidade de São Paulo, para o conjunto das disciplinas petrográficas.

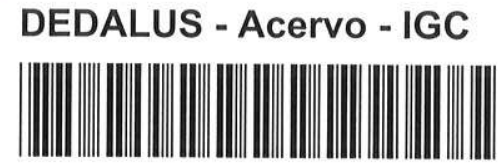

30900004813 
INDICE

CAPITULO I

INTRODUÇĀO

AGRADECIMENTOS

METODOS EXPERIMENTAIS

1 - DETERMINAÇOES POTĂSSTO-ARGÔNIO

2 - DETERMINAÇÖES RUBIDIO-ESTRÔNCIO

CAPITULO III

GEOLOGIA

1 - AREA GRANULITICA SETENTRIONAL

2 - METASSEDIMENTOS DO GRUPO RIO PARDO

3 - AREA GNAISSICA E GRANITTICA MERIDIONAL

DADOS GEOCRONOLOGICOS

A - Complexo granulitico de Jequié

B - Metassedimentos do Grupo Rio Pardo 
$D$ - Rochas graniticas e gnaissicas do sur da Bahia, leste de Minas Gerais e norte do Espirito Santo

$E$ - Rochas intrusivas alcalinas do sul do Estado da Bahia

CAPITULO V

EVOLUÇÃO GEOLŐGICA REGIONAL

$A$ - Ciclo orogênico Guriense

B - Ciclo orogênico Trans-Amazônico.

C - Eventos intermediärios, entre os Ciclos Trans-Amazônico e Brasiziano

$D$ - Ciclo orogênico Brasiziano

E - Sintese de evolucão geolögica regional

CORRELAÇÖS COM O PADRÃO GEOCRONOLOGICO DA ĀFRICA EQUATORIAL

B I BL I OGRAF I A

APENDICE 1

APENDICE 2

APENDICE 3 


\section{INDICE DAS ILUSTRAÇÕES}

FIGURA 1 - Comparação entre análises de rubídio pelos métodos de diluição isotópica

e absorção atômica

FIGURA 2 - Comparação entre os resultados da re lação $\mathrm{Rb}^{\text {tot }} / \mathrm{Sr}^{\text {tot }}$ pelos métodos de diluição isotópica e fluorescência de raios $\mathrm{X}$

FIGURA 3 - Localização das amostras estudadas, ârea setentrional

FIGURA 4 - Localização das amostras estudadas, ārea meridional

FIGURA 5 - Mapa geológico esquemático dà região costeira do Brasil, entre Salvador e Vitória

FIGURA 6 - Diagrama isocrônico do granulito JE-13

FIGURA 7 - Isócronas de referência das rochas granulíticas do Complexo de Jequié

FIGURA 8 - Isócronas de referência dos metasse dimentos do Grupo Rio Pardo

FIGURA 9 - Diagrama isocrônico do migmatito CÃ-78 


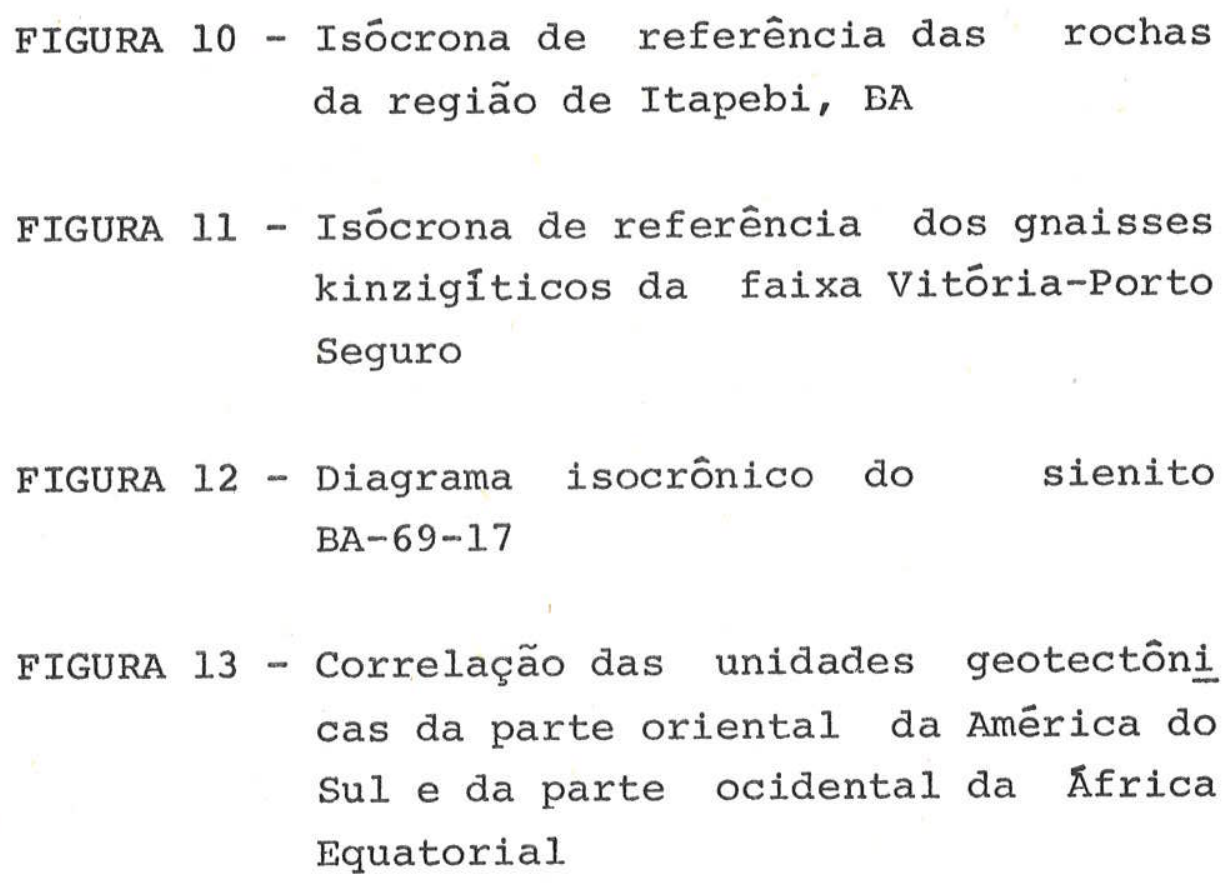

TABELA 1 - Idades $\mathrm{K}-\mathrm{Ar}$ de rochas do complexo granulîtico de Jequié

TABELA 2 - Idades $\mathrm{K}-\mathrm{Ar}$ de rochas da região de Salvador

TABELA 3 - Idades $\mathrm{K}-\mathrm{Ar}$ dos metassedimentos do Grupo Rio Pardo

TABELA 4 - Idades $\mathrm{K}-\mathrm{Ar}$ de rochas da região sul da Bahia e nordeste de Minas Gerais 
TABELA 5 - Idades $\mathrm{K}$-Ar de rochas da região les te de Minas Gerais e Espirito Santo

TABELA 6 - Idades $\mathrm{K}-\mathrm{Ar}$ de rochas alcalinas do sul do Estado da Bahia 
RESUMO

Este trabalho apresenta o estudo geocronológico, pe los métodos $K$-Ar e Rb-Sr, da faixa costeira oriental brasi leira, entre salvador e vitöria. Tal estudo é crîtico para - entendimento da evolução geolōgica geral da Plataforma Bra sileira, e, além disso, permite comparar o padrão geocronolō gico da região focalizada, com aquele encontrado na faixa costeira do continente africano, que the teria sido adjacen te, nas reconstruções efetuadas levando-se em conta a teoria da deriva dos continentes.

Foram efetuadas 62 anālises $K$-Ar, no laboratōrio do Centro de Pesquisas Geocronolögicas, em São Paulo, e 43 anā lises Rb-Sr, a maioria das quais no Centre belge de Géochro nologie, em Bruxelas. As determinações $K$-Ar foram obtidas em minerais separados, principalmente biotitas e anfibólios, enquanto que as anālises $R b$-Sr foram efetuadas apenas em ro cha total, tendo sido interpretadas atravers de diagramas is $\underline{0}$ crônicos.

A maioria das amostras foi coletada pelo autor, que selecionou as mais adequadas para o estudo geocronológico, a partir de um lote de 500. O exame petrográfico, aliado ao controle de campo, permitiu caracterizar quatro grandes uni dades litolōgicas: a ārea granulitica setentrional, a região dos metassedimentos do Grupo Rio Pardo, a região costeira me ridional de gnaisses kinzigiticos, e a faixa mais interna com predominância de rochas gnäissicas e graniticas. Rochas vulcânicas e sub-vulcânicas apareceram, cortando as estrutu ras metamōrficas. 
A anālise dos dados geocronológicos, baseada na in terpretação de três diagramas isocrônicos, vārias isōcronas de referencia, e dos resultados $k$-Ar, levou ao seguinte es quema para a evolução geolögica regional:

$4200 \mathrm{~m} . a$.

$2700 \mathrm{~m} . a$.

$2000 \mathrm{~m} . a$.

$1700 \mathrm{~m} . \mathrm{a}$.

$1300-1600$ m.a.

$760 \mathrm{~m} \cdot \mathrm{a}$.

$650 \mathrm{~m} \cdot a$.

$450-500 \mathrm{~m} \cdot a$.

- 1?) Formação de algumas rochas da ārea de Mutuipe, BA.

- Ciclo Guriense - Formação dos granulí tos do Complexo de Jequié.

- Ciclo Trans-Amazônico - Formação dos granulitos de salvador e dos gnaisses kinzigiticos meridionais. Fenômenos de rejuvenescimento no Complexo de Jequié.

- Resfriamento do craton de salvador.

- Vulcanismo basāltico na região de salva dor. Formação dos gnaisses de Itapebi.

- Intrusões alcalinas no sul da Bahia.

- Ciclo Brasiliano. Metamorfismo no Gru po Rio Pardo. Formação elou rejuvenes cimento de rochas na baixa costeira me ridional.

- Resfriamento da parte oriental da Plata forma Brasileira.

Finalmente, a comparação com os dados disponiveis do lado africano permitiu verificar grandes semelhanças no padrão de evolução geológica global. Em adição, a posição das provincias geocronológicas é compatīvel com a reconstru ção da situação "pré-deriva" dos continentes analisados. Tais evidências são altamente favorāveis ao modelo geodinâmico de evolução terrestre que inclui um episódio de deriva dos con tinentes, no Fanerozōico. 


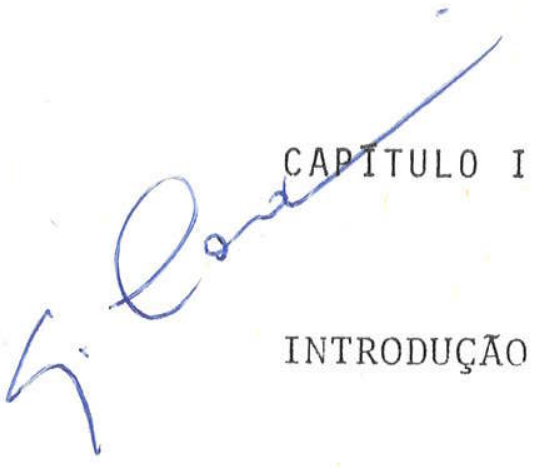
ficados no campo das geociências. Os fenômenos geodinâmicos começaram a ser considerados conjuntamente, o que possibili tou o aparecimento de modelos integrados para explicar os processos geológicos de escala continental.

são dos mais atuais os problemas do aparecimento e da histōria geológica do material granîtico que caracteriza as massas continentais. Acumulam-se a esse respeito dados pro venientes de vārias especialidades das geociências, tais cô mo a geotectônica, a geoquímica, a sismologia, etc. Tratando-se de problemas de evolução geológica, desde os primōrdios da formação de nosso planeta, tornam-se essericiais dados geo cronológicos, visto que durante a maior parte da histōria dá Terra, no Prē-Cambriano, fösseis são raramente disponĩveis, e ainda não são empregados adequadamente nas correlações.

No mundo inteiro foram efetuadas algumas dezenas de milhares de determinações geocronolögicas, em rochas prë-cam brianas das áreas continentais. Tais dados permitem um grau de conhecimento razoável da evolução de certas províncias geotectônicas, tais como o Escudo Canadense, o Escudo Bâltí co, a Plataforma Russa e mesmo de algumas āreas pertencentes a continentes menos conhecidos, como a Africa ou a Austrälia. Algumas faixas de dobramentos antigas já têm sua evolução geológica praticamente esclarecida.

A Plataforma Brasileira (A Zmeida, 1967), unidade geo tectônica estabelecida no final do Prē-Cambriano e início do Paleozóico, que comportou-se rigidamente durante a evolução do cinturão orogenético Andino, é uma das massas graníticas 
continentais menos conhecidas. Estudos e mapeamentos geoló gicos recentes, efetuados principalmente na década de 60 , mui tos atualmente em andamento, continuam a acumular conhecimen tos geológicos a respeito desta grande região. Determinações geocronológicas ainda são escassas, em número insuficiente para permitir uma interpretação adequada da evolução da pla taforma Brasileira. Com exceção de datações esparsas, e dos estudos efetuados por geólogos do US Geological Survey no Quadrilátero Ferrífero, MG, os dados radiométricos atualmen te existentes, a respeito de rochas pré-cambrianas do terri törio brasileiro foram obtidos no Centro de Pesquisas Geocró nológicas da Universidade de são Paulo (CPGeo), ou em laborá tórios estrangeiros, em programas de cooperação científica com o CPGeo.

A região focalizada no presente estudo, a faixa cos teira oriental brasileira, entre Salvador e Vitória, ainda não foi objeto de mapeamento global, sendo bem conhecida, geo logicamente, apenas em seu trecho próximo do rio Pardo, no sul do Estado da Bahia. Entretanto, para a compreensão das evolução geral da Plataforma Brasileira, esta região apresen ta grande importância, visto que contēm a parte leste-sudes te da unidade geotectônica denominada craton do são Francis co, e a sua delimitação com a faixa de dobramentos Ribeira, região orogênica ativa durante o fim do Pré-Cambriano, que se estende ao longo da costa, em direção ao sul, até o Uru guay.

Grande importância adicional é apresentada por este trecho, entre Salvador e Vitōria, em vista de sua comparação com a região correspondente do continente africano, ou seja o trecho costeiro entre Gabon e Angola, que the teria sido adjacente, nas reconstruções efetuadas, levando-se em conta a teoria da deriva dos continentes. Para a região costeira a norte de Salvador, a comparação com o continente africano foi efetuada em trabalho anterior (Iurley et al., 1967), o 
qual apresentou resultados altamente positivos. Para a par te sudeste do Brasil, já existem dados suficientes para per mitir comparação entre o cinturão orogênico Ribeira, do lado sul-americano, e o cinturão orogênico Damara, de idade compa rável, do lado africano. Neste trabalho, os dados apresenta dos possibilitam um confronto adequado entre as regiões res tantes, completando o quadro comparativo, teste fundamental para a teoria da deriva continental.

Para o desenvolvimento da presente pesquisa, o au tor coletou pessoalmente a grande maioria das amostras, duran te värias expedições científicas à região, efetuadas em outu bro de 1968, julho de 1969, julho de 1970, e janeiro de 1973. Algumas das amostras disponivveis foram cedidas por värios geólogos, a saber S. Fujimori, A. J. Pedreira, P. G. Souto, H. Azevedo; J. Mascarenhas e C. Durrell. Algumas outras, ce didas pela Petrobrás, foram analisadas, em São Paulo, por A. Thomaz, que permitiu a inclusão dos dados neste trabalho.

Do conjunto de rochas existentes, cerca de 500, fo ram escolhidas as mais adequadas para o estudo geocronológi co, com base na natureza do material e na distribuição geo grăfica e geológica. Para isto foi efetuado o estudo petro gräfico de todas as amostras disponiveis a fim de caracteri zar as principais unidades geológicas da região. As anāli ses $\mathrm{K}$-Ar foram todas realizadas em São Paulo, enquanto que a maioria das determinações $\mathrm{Rb}-\mathrm{Sr}$, por diluição isotōpica, fo ram efetuadas em Bruxelas, durante estágio de laboratōrio que o autor desenvolveu junto à Université Libre de Bruxelles (ULB), como Professor Visitante, no primeiro semestre de 1971. As demais determinações $\mathrm{Rb}-\mathrm{Sr}$ foram realizadas em são Paulo, em ëpoca posterior.

Integram este trabalho 62 anâlises K-Ar, e 43 anāli ses $\mathrm{Rb}-\mathrm{Sr}$. Determinações incluidas em trabalhos anteriores (Hurley et al., 1967, Almeida et al., 1968, Delhal et al., $1969)$ são aqui re-avaliadas, nas interpretações integradas., 
tendo em vista os novos resultados obtidos.

\section{AGRADECIMENTOS}

De início, o autor deseja agradecer aos geólogos P.G. Souto, A.J. Pedreira e H. Azevedo que na época perten ciam à CEPLAC, pela ajuda prestada durante a coleta de amos tras, nas expedições efetuadas em 1969 e 1970. Da ültima ex pedição participou tambēm o geólogo paulista P.C. Abrão.

Nos trabalhos analíticos no Centro de Pesquisas Geo cronológicas, em São Paulo, os técnicos M. Elissa Correa da Silva Lucena e J. Roberto de Medeiros auxiliaram, respectiva mente, nas análises de potássio e na preparação das amostras e separação de minerais. O tëcnico C. dos Santos e os estu彑 dantes bolsistas Miguel A.S. Basei, Agostinho F. Sobreiro Ne to e Paulo M. de Mendonça efetuaram muitas das extrações de argônio e cálculos de idade $\mathrm{K}$-Ar. Ao Dr. Marcos Berenholc são devidas as determinações quantitativas de lRb e $\mathrm{Sr}$ por fluorescência de Raios X e ao Dr. K. Kawashita algumas anāli ses de Sr.

Os técnicos do Instituto de Geociências da Universí dade de São Paulo, Melany T. Isauk e Deocleciano Soares de Araujo, confeccionaram as lâminas delgadas das rochas estuda das. O sr. José Ponchirolli e a sra. Nair de C. Louzada, tam bém do I.G., são os responsáveis pelos trabalhos de datilo grafia. đ Srta. Namie Koseki cabem as ilustrações.

No Centre Belge de Géochronologie, onde o autor exe cutou a maioria das anälises $\mathrm{Rb}-\mathrm{Sr}$ deste trabalho, o seu treinamento foi possibilitado pelo auxilio dos pesquisadores S. Deutsch, D. Ledent e P. Pasteels. O autor agradece ainda. ao Dr. E. Picciotto, e ao Dr. J. Michot, responsäveis respec tivamente, pelo Service de Géologie et de Géochimie Nucleai res, e pelo Service de Minëralogie et Petrologie da Univer sitē Libre de Bruxelles por terem gentilmente colocado à dị posição do autor suas instalações. 
Os geölogos paulistas E. Wernick e V.A.V. Girardi, bem como o petrólogo belga J. Delhal, do Musée Royal de l'Afrique Centrale, de Terveuren, ofereceram ao autor ajuda importante nas anālises petrográficas, em especial na identi ficação de minerais de rocha menos comuns.

Finalmente, o autor deseja consignar seu reconheci mento ao Dr. L. Cahen, "expert" em geologia africana e ao geólogo J.R.F. Torquato, do Serviço Geológico da Província de Angola, pelas proveitosas discussões mantidas, bem como aos geölogos Juracy F. Mascarenhas e P.G. Souto, pelas valio sas informações prestadas sobre a geologia da região orien tal baiana.

A Fundação de Amparo à Pesquisa do Estado de São Paulo financiou os trabalhos de campo, e complementou a bol sa do governo belga que permitiu o estägio de laboratório do autor em Bruxelas. O Conselho Nacional de Pesquisas presta continuadamente ajuda ao CPGeo, o que permite a execução das anālises geocronolögicas em são Paulo. As determinações geo cronolögicas em Bruxelas foram efetuadas com a autorização do Centre Belge de Gēochronologie. 
CAPITULO II

\author{
METODOS EXPERIMENTAIS
}

1 - DETERMINAĢひES POTASSIO-ARGONIO

As análises $\mathrm{K}-\mathrm{Ar}$ que constam deste trabalho foram efetuadas nos laboratörios do Centro de Pesquisas Geocronoló gicas em são Paulo. Uma descrição completa das técnicas em pregadas pode ser encontrada em Amaral et al., (1966).

As anälises de potássio foram efetuadas em duplica ta, por fotometria de chama, com padrão interno de lítio. Pa ra as determinações constantes deste trabalho, o erro percentual médio, em relação à mëdia, foi de aproximadamente $0,8 \%$.

As anälises de argônio, por diluição isotópica, fo ram efetuadas no espectrômetro de massa tipo Reynolds, do CPGeo, tendo sido empregado traçador de $\mathrm{Ar}^{38}$ puro. Para cer ca de dois terços das determinações, foram utilizados traça dores previamente preparados, em conjuntos de aproximadamen te 430 unidades, segundo o método preconizado por Reynolds e spira (1966). As restantes foram efetuadas mediante empre go de aliquotas calibradas retiradas sucessivamente de um re servatörio.

A precisão das medidas foi calculada em cada caso, mediante estudo envolvendo propagação de erro, desenvolvido no CPGeo. As estimativas dos erros experimentais para cada amostra, que dependem pois da qualidade das medidas efetua das, e de parâmetros estatisticos determinados experimental mente no laboratório, foram incluídas no Apêndice 2, onde constam os dados analíticos completos referentes às análises $\mathrm{K}-\mathrm{Ar}$ realizadas. Verifica-se que as determinações $\mathrm{K}-\mathrm{Ar}$ es tão sujeitas a erro experimental variando entre 1 e 10\%,com 
média por volta de $4 \%$ e distribuição bi-modal, sendo mais precisas as anālises efetuadas mediante reservatörio de $\mathrm{Ar}^{38}$ (entre 1 e $3 \%$ de erro), em relação às demais (entre 2 e 10\% de erro).

Neste trabalho não houve preocupação de demonstrar a reprodutibilidade das medidas đe argônio, característica jä suficientemente testada no CPGeo. Entretanto, podem ser vir de indicação os resultados obtidos para a biotita ITB-219, que foi analisada 15 vezes, por ser amostra-padrão in tra-laboratörio, empregada para calibrar os diferentes siste mas de traçadores de argônio 38. Os resultados obtidos apre sentaram desvio percentual médio de $1,9 \%$ em relação ao valor médio, o que demonstra a boa reprodutibilidade do laboratório.

As constantes empregadas nos cälculos foram:

$$
\begin{aligned}
\lambda_{B} & =0,530 \times 10^{-9} \text { anos }^{-1} \\
\lambda_{E} & =0,585 \times 10^{-10} \text { anos }^{-1} \\
& \& \text { atom. de } \mathrm{K}^{40} \text { em } \mathrm{K}^{\text {tot }}=0,0119
\end{aligned}
$$

2 - DETERMINACOES RUBIDIO-ESTRONNCIO

A maioria das determinações $\mathrm{Rb}-\mathrm{Sr}$ aqui apresentadas foram efetuadas pelo autor, por diluição isotópica, nos labo ratórios do Centre Belge đe Gēochronologie, em Bruxelas. o tratamento químico seguiu o procedimento habitual, de acordo com Deutsch et al. (1965). Nas anālises de Rb e de Sr, fo ram empregados, respectivamente, traçadores enriquecidos em $\mathrm{Rb}^{87}$ e em $\mathrm{Sr}^{84}$.

Com exceção de três, as anälises de Sr por diluição isotópica foram obtidas em espectrômetro Varian-Atlas tipo CH4, de 6" de raio de curvatura, cujo comportamento habitual permite um erro experimental inferior a $0,2 \%$ na obtenção daṣ 
relações isotōpicas do $\mathrm{Sr}$. As três restantes foram obtidas em espectrômetro de massa de 30 centímetros de raio de curva tura do Service de Géologie et de Géochimie Nucleaires da ULB. (Reinharz et al., 1962). Nestes casos, a precisão ob tida foi inferior, em virtude das instabilidades de emissão verificadas durante as anālises. Todas as anālises de Sr fo ram normalizadas, admitindo-se $\mathrm{Sr}^{86} / \mathrm{Sr}^{88}=0.1194$.

Neste mesmo espectrômetro foram efetuadas quase to das as medidas de $\mathrm{Rb}$ por diluição isotópica constantes do trabalho. Uma delas (amostra pobre em $\mathrm{Rb}$, e misturada ao traçador em quantidade inadequada) foi analisada no espectrô metro $\mathrm{CH}_{4}$, enquanto que três outras foram analisadas por C.A. Cingolani em espectrômetro de massa Nuclide, pertencen te ao I.N.G.E.I.S. (Buenos Aires). Como é impossível uma correta avaliação dos efeitos de fracionamento isotópico du rante as anālises de $\mathrm{Rb}$, vārias amostras de $\mathrm{Rb}$ natural foram analisadas, e o valor médio obtido foi utilizado para calcu lar o fator de correção. De qualquer modo, as análises de $\mathrm{Rb}$ por diluição isotópica estão sempre sujeitas a erro analí tico da ordem de 1-2\%.

Como verificação adicional para as determinações de $\mathrm{Rb}$, foi empregado o método de absorção atômica, segundo a técnica desenvolvida por Vosters e Deutsch (1967) e Gamot et al. (1970). As medidas foram feitas pelo autor, no instru mento Perkin Elmer do Service de Gẻologie et de Géochimie Nucleaires da ULB. A Figura 1 mostra a comparação entre os dados de absorção atômica e diluição isotópica obtidos, podendo-se verificar uma boa concordância em quase todos. Algu mas diferenças significativas que aparecem (ver por exemplo as amostras ITC-29, $\mathrm{BJ}-10$ ou BA-69-17C), foram provavelmente ocasionadas por problemas quimicos ocorridos nas soluções que foram medidas por absorção atômica. Tendo em vista tal inconveniente, apenas as medidas por diluição isotópica fo ram levadas em conta nos cálculos. 


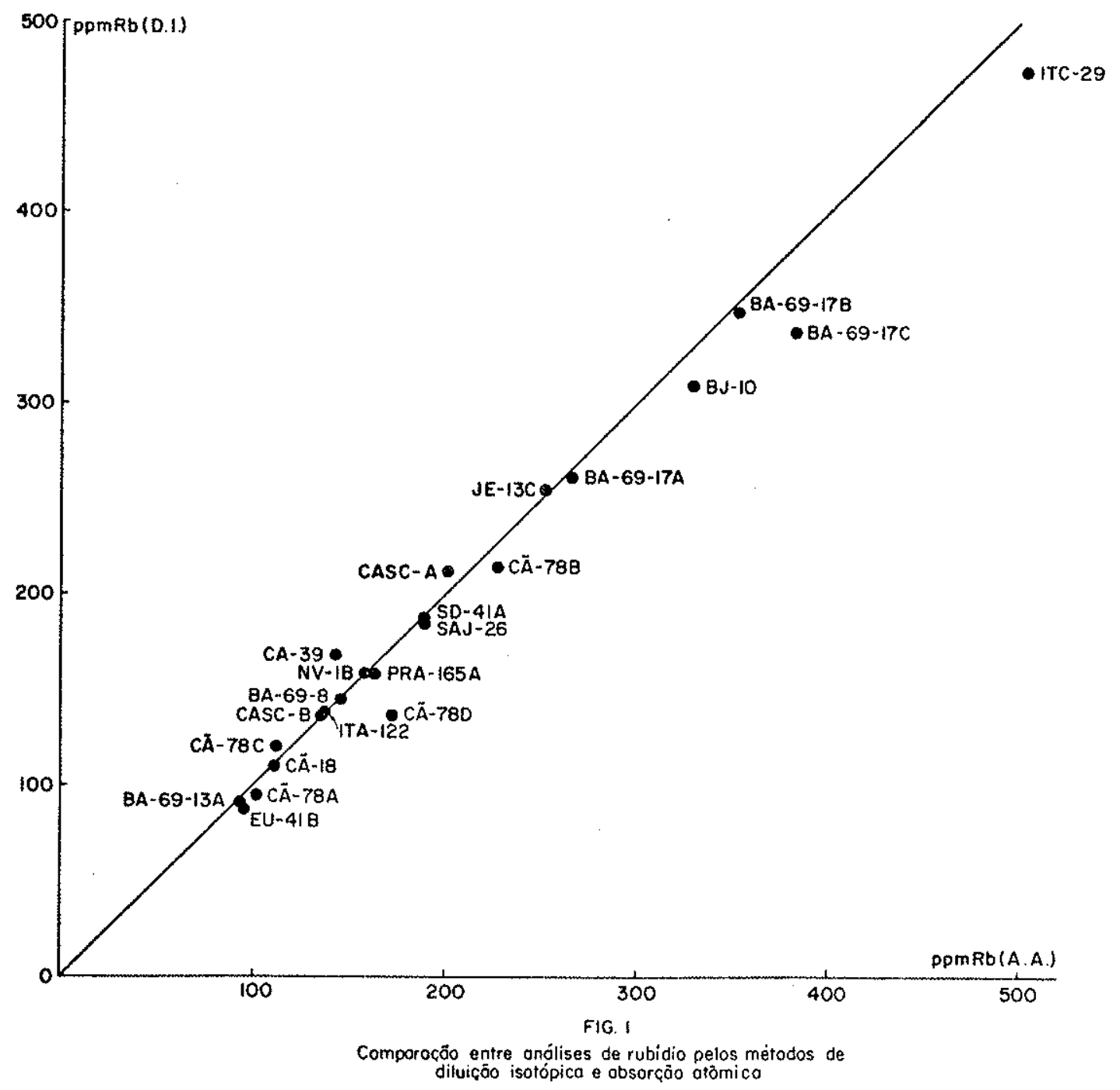

Onze amostras foram datadas pelo método $\mathrm{Rb}-\mathrm{Sr}$, no CPGeo, em São Paulo, utilizando-se determinações quantitati vas de $\mathrm{Rb}^{\text {tot }} \mathrm{e} \mathrm{Sr}^{\text {tot }}$, por fluorescência de Raios $\mathrm{X}$, e anälí ses de composição de $S r$, sem traçador, de acordo com a técni ca utilizada por Kawashita (1972). Destas onze determina ções de composição isotōpica de $\mathrm{Sr}$, cinco foram efetuadas por K. Kawashita no espectrômetro de massa tipo Reynolds do CPGeo, ao qual foi adaptada uma fonte sólida, enquanto que 
as seis restantes foram obtidas pelo autor, no recēm adquiri do espectrômetro Varian-Mat, tipo TH-5 do CPGeo. Estas fo ram as primeiras determinações de $\mathrm{Sr}$ efetuadas com tal ins trumento que aparenta possuir grande precisão. Algumas anā lises efetuadas, no mesmo período, da relação $\mathrm{Sr}^{87} / \mathrm{Sr}^{86}$ no pá drão Eimer Amend apresentaram valor médio de 0,7077, muito próximo ao preconizado. $\left(\mathrm{Sr}^{87} / \mathrm{Sr}^{86}=0.7082\right.$, Hildreth e Henderson, 1971.) Kawashita (1972) verificou a concordân cia, dentro dos limites de erros experimentais, entre deter minações efetuadas por fluorescência de Raios x, no CPGeo, e determinações normais por diluição isotōpica.

A Figura 2 mostra a concordância obtida entre os dạ dos obtidos, neste trabalho, por fluorescência de Raios $\mathrm{X}$, com aqueles por diluição isotópica. Foi elaborada levando-se em conta as razões $\mathrm{Rb}^{\text {tot } / \mathrm{Sr}}{ }^{\text {tot }}$, que são os parâmetros sig nificativos no cálculo das idades e no traçado das isōcronas. As determinações individuais de $\mathrm{Rb}^{\text {tot }}$ e de $\mathrm{S} x^{\text {tot }}$, por fluo rescência de Raios $\mathrm{x}$, entretanto, resultaram sistematicamen te cerca de $5 \%$ mais elevadas do que as obtidas em Bruxelas, por diluição isotōpica (vide Apêndice 3), o que se deve, pro vavelmente, a diferenças entre os padrões utilizados em am bos os laboratórios. o assunto encontra-se sob investigação. De qualquer modo, como os valores $\mathrm{Rb}$ tot $/ \mathrm{Sr}$ tot apresentam grande concordância, as medidas efetuadas por fluorescência de Raios X em São Paulo podem ser tratadas conjuntamente à quelas obtidas por diluição isotōpica. Para a construção de isócronas, nos casos em que havia valores provenientes de vărios mētodos (D.I., A.A., F.X.), sempre foram utilizados aqueles referentes à diluição isotópica, método menos sujei to a erros devidos a interferências. A única exceção foi re lativa à amostra CÃ-75 B, que apresentou valores concordan tes para as determinações de rubídio por A.A. e F.X. Neste caso foi desprezado o valor obtido por D.I., tendo em vista um possivel erro aciaental. 


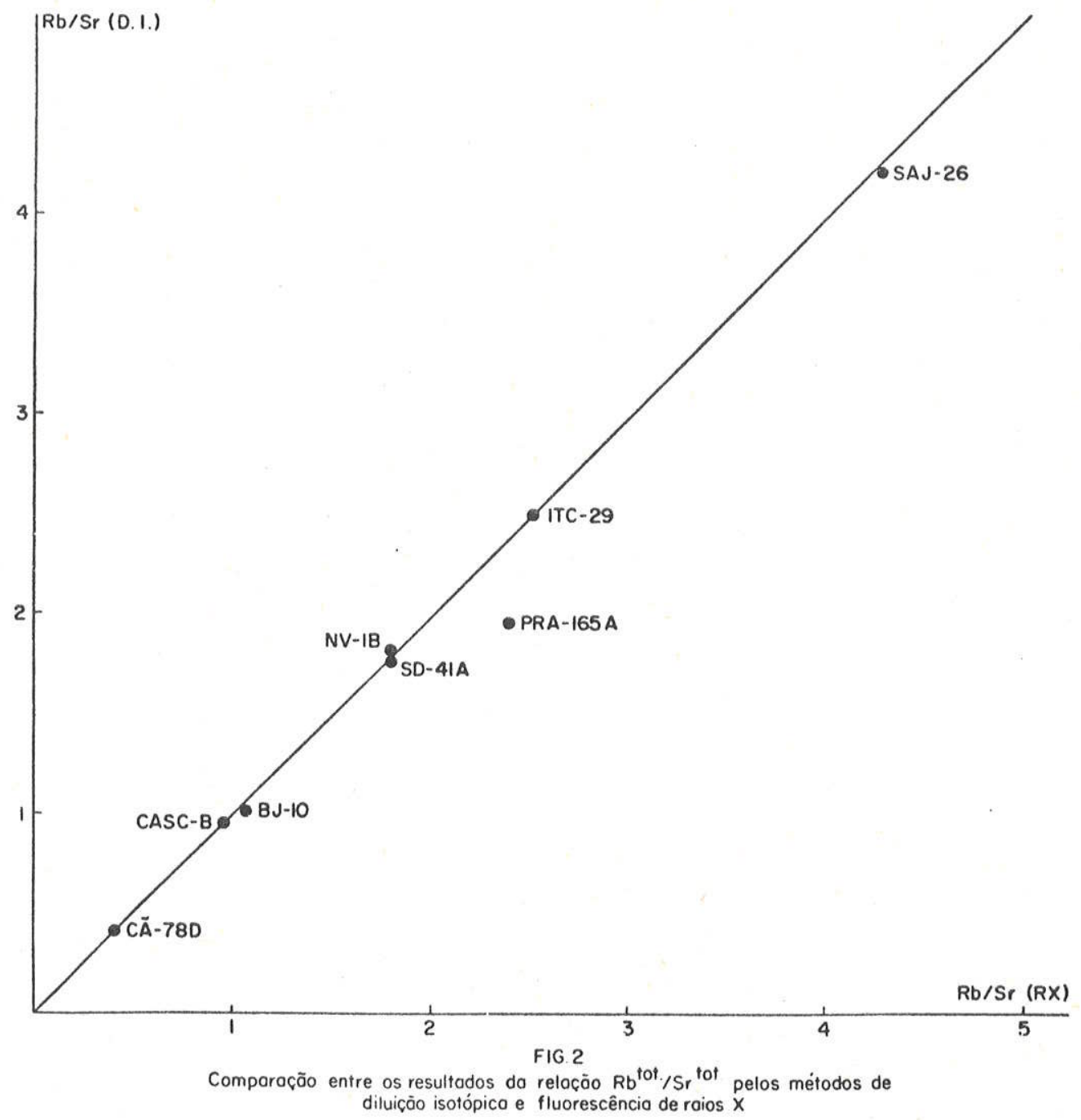

Os dados analiticos $\mathrm{Rb}-\mathrm{Sr}$ completos foram incluidos no Apêndice 3. Em virtude da variedade de tēcnicas e instru mentos utilizados, neste apêndice tambēm foram incluídas re ferências sobre metodologia empregada em cada determinação. As isöcronas das Figuras 6 a 12 foram traçadas segundo uma regressão linear simples, de acordo com o procedimento de Shields (1963). Os calcúlos foram efetuados mediante empre go do programa PCRONO (X em Y), desenvolvido em linguagem Fortran IV e adaptado para o computador Bourroughs/3500 do 
Centro de Computação Eletrônica da Universidade de são Paulo. As estimativas dos erros analiticos referem-se ao nivel de confiança de $688(1 \sigma)$.

As constantes empregadas nos cälculos foram:

$$
\begin{aligned}
& \lambda_{\mathrm{Rb}}=1,47 \times 10^{-11} \mathrm{anos}^{-1} \\
& \mathrm{Rb}^{85} / \mathrm{Rb}^{87}=2,59 \\
& \mathrm{Sr}^{86} / \mathrm{Sr}^{88}=0,1194
\end{aligned}
$$


CAPITULO I I I

\author{
GEOLOG IA
}

A região objeto do presente estudo estende-se ao longo da costa oriental brasileira, entre os paralelos $12^{\circ} \mathrm{S}$ e $20^{\circ} 30^{\prime} \mathrm{S}$, aproximadamente, incluindo, em suas extremidades, as cidades de Salvador (BA) e de Vitória (ES). A extensão total, ao longo da costa, perfaz cerca de $1100 \mathrm{~km}$. A faixa investigada apresenta uma largura variävel, entre 100-150 km, desde Salvador atë o rio Jequitinhonha; daí para o sul, algu mas amostras foram coletadas até cerca de $200 \mathrm{~km}$ de distân cia da coṣta. Em outras palavras, a ärea em questão situa-se entre o litoral e a rodovia BR-116, no trecho entre as cidades de Feira de Santana (BA) atē Manhuaçu (MG), e compreende cerca de 200000 quilômetros quadrados.

Interpretações geocronolōgicas regionais, como a que é apresentada neste trabalho, necessitam de um conheci mento geológico de base, para poder aquilatar a influência dos diferentes eventos geolōgicos, e caracterizä-los adequa damente. São especialmente úteis mapas geológicos regionais, em escalas tais como 1:250.000, que mostrem as relações de campo das principais unidades litolögicas.

Infelizmente, apenas uma pequena parte da área, re ferente à bacia do baixo rio Pardo, apresenta-se mapeada, geo logicamente, em escala adequada. Deixamos de mencionar aqui os inúmeros trabalhos referentes às bacias costeiras pōs-pa leozóicas (Recôncavo, Tucano, Almada, Espỉrito Santo, etc.), desenvolvidos nas últimas dêcadas pela equipe técnica da Pe trobrās; tais trabalhos, em geral, não dão atenção à geolo gia do embasamento, apresentado sem diferenciação nos seus mapas geológicos. 
Pedreira et al. (1969) apresentam uma sintese dos le vantamentos geológicos realizados na região do baixo rio Par do, e a equipe tëcnica da CEPLAC está editando, paulatinamen te, os trabalhos resultantes, com maiores detalhes (Azevedo, 1969; Azevedo e Souto, 1971; Souto et al., 1971; Souto et al., 1971a; Souto et al., 1972; Barbosa de Deus, 1972). Tais le vantamentos geológicos mostram-se adequados para as intexpre tações geocronológicas; as expedições de coleta de amostras na região (entre $15^{\circ}$ e $16^{\circ}$ de latitude sul), efetuadas pelo autor, levaram em conta os dados existentes.

Tambēm na parte meridional da região estudada, no Es tado do Espirito Santo, faz-se disponível uma carta geológi ca global (Brajnikov, 1955), onde estão delimitadas as prin cipais unidades litológicas do embasamento. Tal trabalho é de grande utilidade como controle litológico, se não se atri buir maior importância à interpretação geológica apresentada, na ocasião, por aquele autor, feita em época anterior à toma da de fotografias aéreas na região. Na presente pesquisa, o mapeamento mencionado foi avaliado, reconstituindo-se os ca minhamentos principais levantados por Brajnikov, e utilizan do os dados do estudo petrográfico de boa qualidade executa do por aquele autor.

Outros trabalhos importantes, que serviram como con trole geológico e/ou petrográfico para as interpretações geo cronológicas aqui apresentadas foram os de Maack (1963) a respeito da região do rio de Contas, o de Fujimori (1967) so bre as rochas alcalinas do sul da Bahia, o do mesmo autor (1968) sobre os granulitos de Salvador, e o de Sighinolfi (1970) sobre os granulitos da região oriental da Bahia. o trabalho de Barbosa et $\alpha$. (1966), a respeito da região do vale do rio Doce também foi levado em conta, extrapolando-se os dados para as regiões contiguas.

Merecem ainda ser mencionados os trabalhos de natu reza petrolögica de Guimarães (1924), Guimarães e Souza (1931), Alzard e Fujimori (1966), Castro e Sial (1971) e Sighinolfi 
e Fujimori (1972), que caracterizam as rochas granuliticas da região de Salvador. Algumas sinteses geológicas globais foram feitas anteriormente, por diversos autores, em vărias oportunidades, analisando e interpretando os sempre escassos dados disponíveis. Lembramos aqui as de Moraes Rego (1947), Guimarães (1951), Ebert (1962 e 1968), Barbosa (1966), Alme da (1967), Susczynski (1967), Cordani et al., (1968), Almeida (1969), e finalmente Ferreira (1972), como autor da notícia explicativa que acompanha a recente Carta Tectônica do Bra sil, em escala 1:5.000.000.

Para a execução do presente estudo geocronológico cerca de 450 amostras foram obtidas em vārias excursões rea lizadas pelo autor, que percorreu as principais rodovias e estradas da região. Outras amostras tornaram-se disponỉveis atravês da ajuda dos vārios geólogos regionais, S. Fujimori, A.J. Pedreira, P.G. Souto, H. Azevedo, J. Mascarenhas, C. Durrell) que cederam alguns exemplares importantes, de luga res pouco acessivveis.

De início, foi feito um estudo petrográfico comple to para caracterizar as unidades geotectônicas principais. Nesta fase, mais de 500 lâminas foram examinađas, com a fina lidade de deduzir, em algumas regiões chave, a sequência de eventos geológicos impressa nas diversas paragêneses mine rais, e selecionar as amostras consideradas mais adequadas para estudos geocronológicos. As Figuras 3 e 4 exibem a lo calização das amostras disponíveis, bem como a denominação de campo das que foram objeto das análises geocronológicas referidas neste trabalho. O Apêndice 1 inclui as descrições petrogrāficas das amostras que foram objeto de datação radio mëtrica.

Fazendo-se abstração dos sedimentos das bacias cos teiras, bem como das extensas coberturas recentes que reves tem os tabuleiros próximos do litoral, podem ser distingui das, do ponto de vista geológico, quatro regiões caracterís ticas, a saber: a área granulítica setentrional, a região 


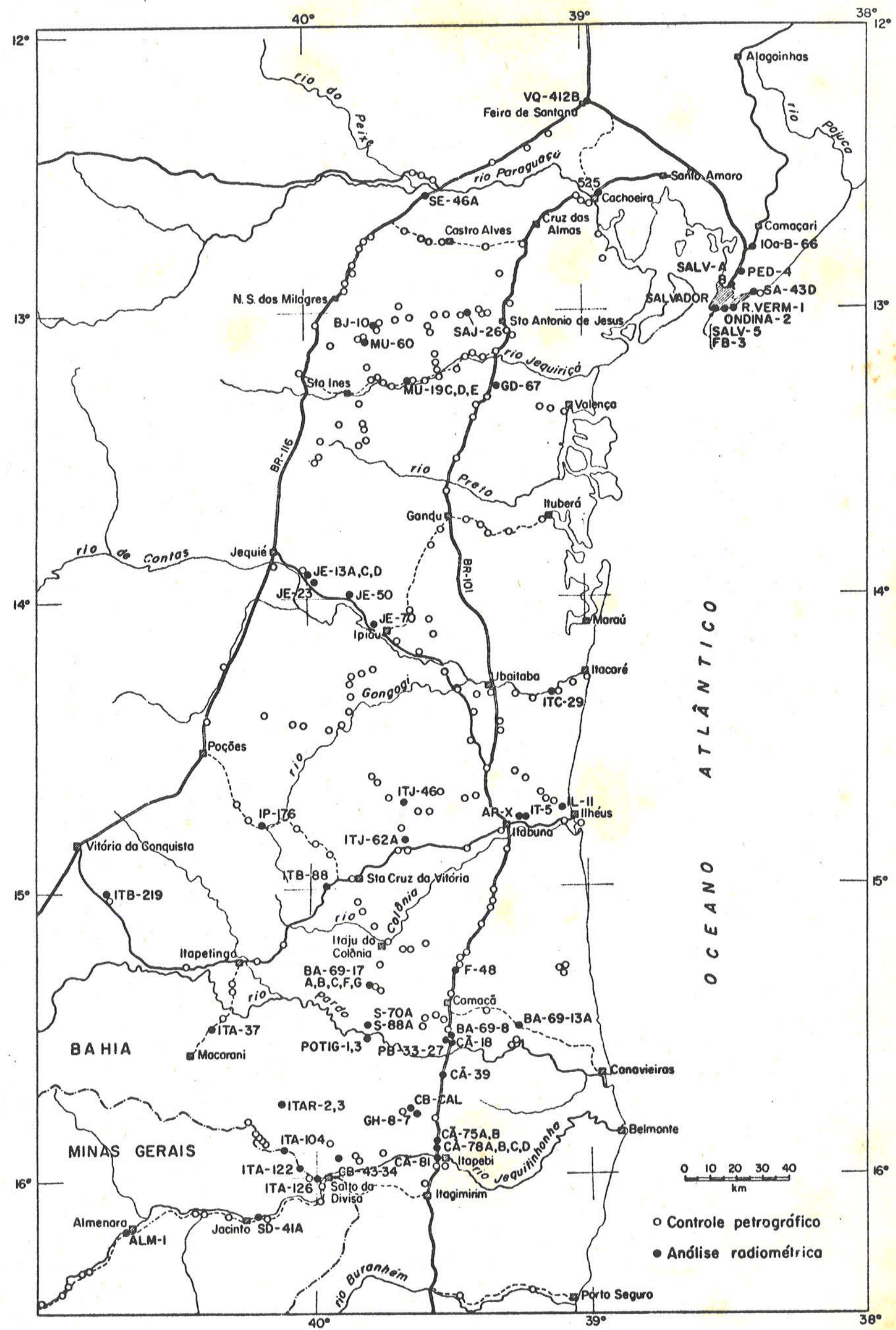

Fig. 3 - Localização das amostras estudadas, ärea setentrional. 


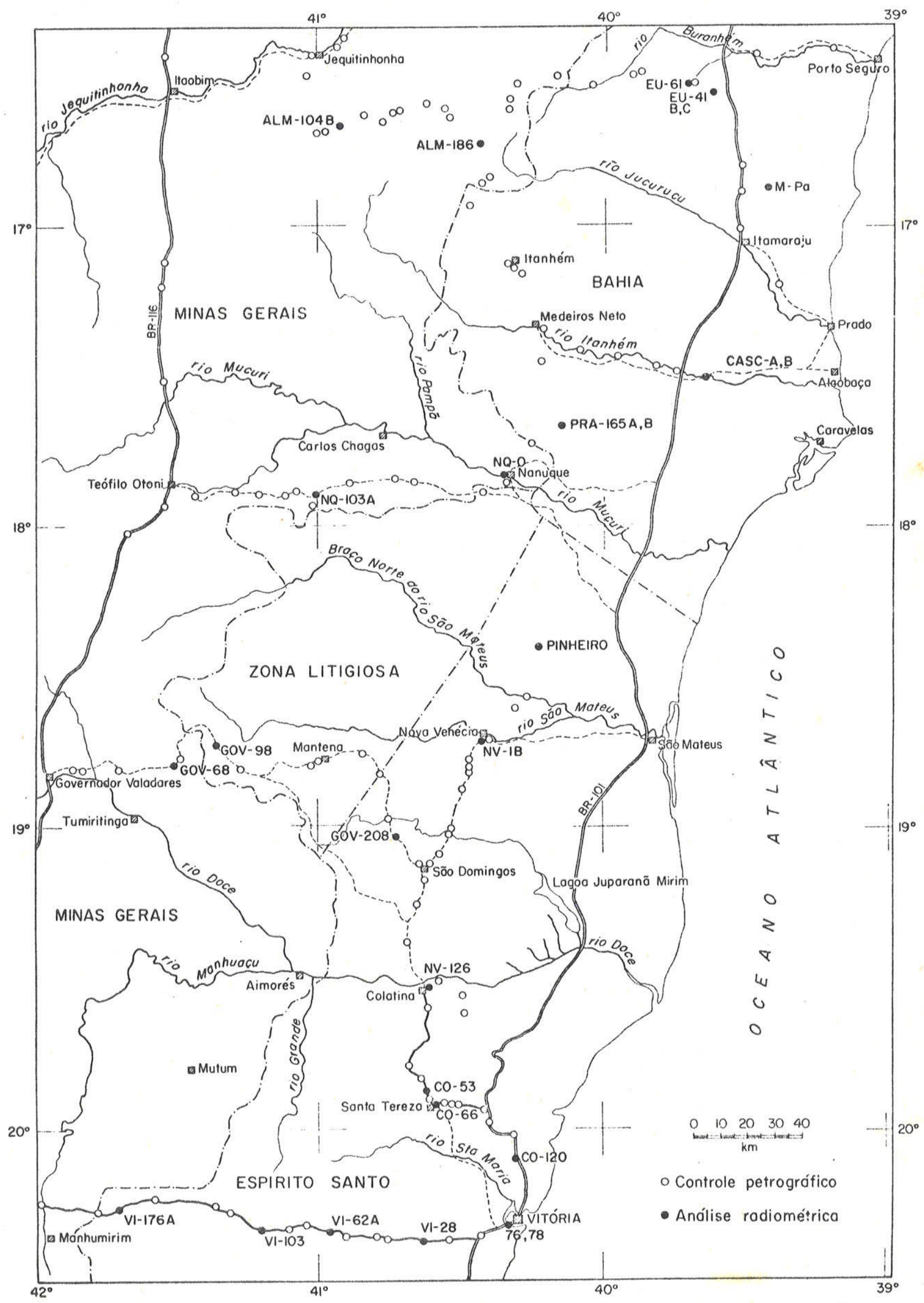

Fig. 4 - Localização das amostras estudadas,ärea meridional 
dos metassedimentos do Grupo Rio Pardo, a região costeira me ridional dos gnaisses granatíferos, e a faixa mais interna com predominância de rochas gnāissicas e graníticas. Rochas vulcânicas e sub-vulcânicas aparecem, localmente, cortando as estruturas metamórficas. Este trabalho procurará, a se guir, caracterizar geologicamente e petrograficamente cada uma das unidades litológicas referidas, enfatizando os prin cipais dados petrológicos que têm interesse diceto para a in terpretação da evolução geológica regional.

A Figura 5 mostra esquematicamente a distribuição das unidades litológicas principais. Foi traçada com base no controle petrogräfico obtido (Figuras 3 e 4 ), e nos traba lhos regionais existentes, jā mencionados (Pedreira et al., 1969; Brajnikov, 1955; Maack, 1963; Fujimori, 1967;

Sighinolfi, 1970; Barbosa et al., 1966). Além disso, para a delimitação das unidades, o autor valeu-se dos mosaicos semi-controlados de radar, editados pelo Departamento Nacional da Produção Mineral (Projeto Radam), que cobrem quase toda a ärea estudada. Em tais mosaicos (SD-24-V-B, SD-24-V-D, $S D-24-Y-B, S D-24-Y-D, S E-24-V-B$ e SE-24-V-D), em escala 1:250.000, as estruturas regionais salientam-se nitidamente, auxiliando as interpretações geológicas. Na Figura 4, foram incluidas as principais zonas de fraturamento, bem como as direções estruturais mais pronunciadas, reveladas pelas ima gens do Radam.

\section{1 - AREA GRANULITICA SETENTRIONAL}

Toda a parte setentrional da região, entre Feira de Santana e o rio Pardo, è formada por rochas granulíticas,com direções estruturais pouco variadas, mantendo-se próximas de N-S ou NNE-SSW, com uma inflexão importante para NW a par tir de Santo Antonio de Jesus. Tais rochas parecem consti tuir uma unidade geotectônica importante sobre o craton do 


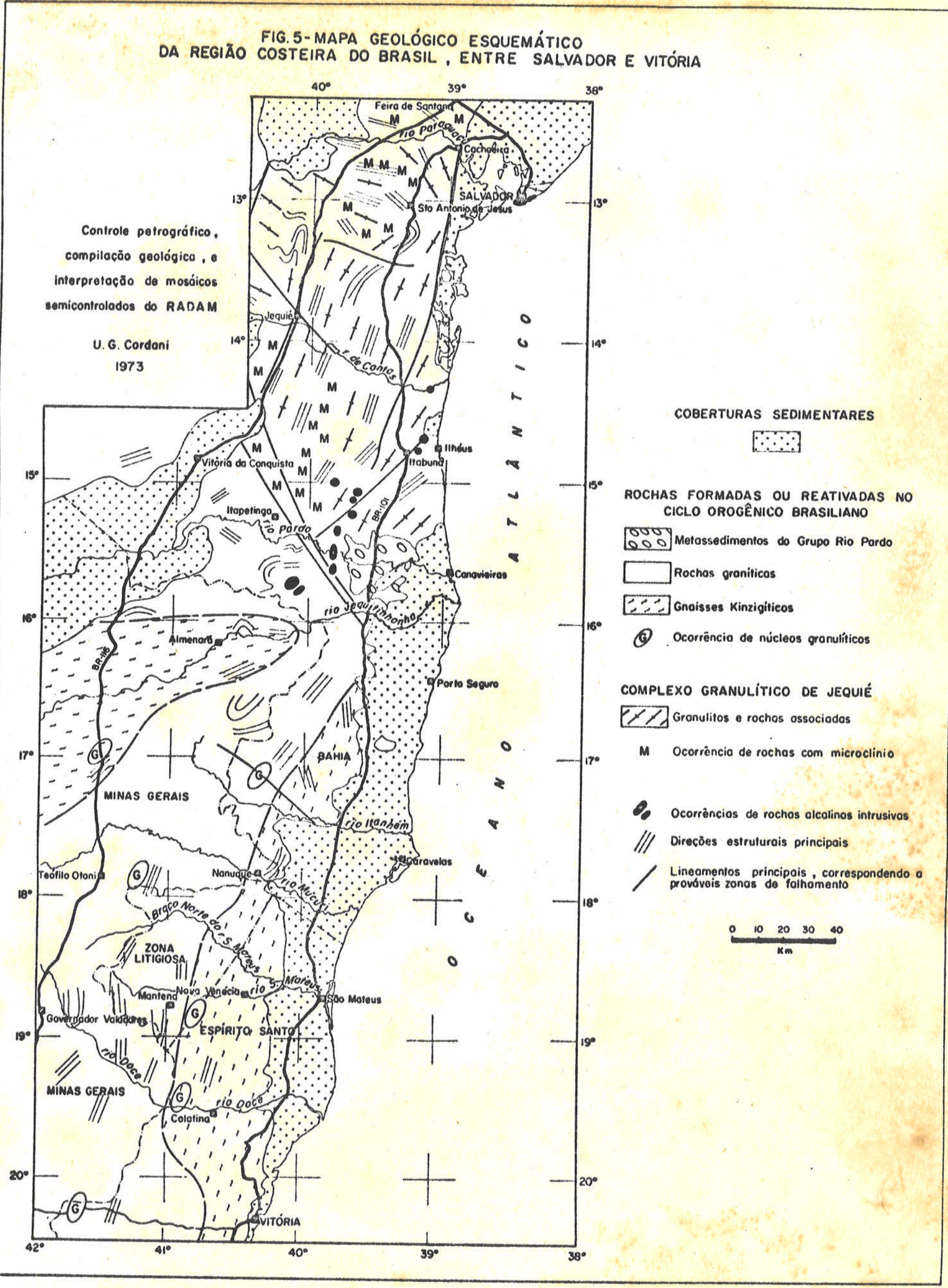


São Francisco, para a qual estā sendo proposta, neste traba Tho, a denominação de "Complexo granulítico de Jequié". So bre os mosaicos do Radam, a região apresenta extensos linea mentos retilíneos, em grande parte concordantes com as prin cipais direções estruturais,que podem ser interpretados como grandes zonas de falhamentos. Os principais foram represen tados na Figura 5. Um deles, que passa próximo às localida des de Poções, Itapetinga, Potiraguá, Itapebi e Itagimirim, parece apresentar importância especial, por constituir o 1 i mite SW da unidade geotectônica granulítica. E bem possível que esta zona tectônica, aqui denominada Falhamento de Itape bi, cuja largura parece ser de alguns quilômetros, continue emdireção NW, infletindo-se em seguida para Norte, passando a constituir parte do sistema de grandes falhas que acompa nham a borda oriental da Chapada Diamantina.

Essencialmente, as rochas que constituem o Complexo de Jequiē são metamōrficas de alto grau, e serão denominadas genericamente de granulitos. Exibem frequentemente nítido bandeamento, granulação fina a mëdia, e por vezes uma gnais sificação irregular. Macroscopicamente, apresentam o bri Iho graxoso e a coloração cinza-azulada ou esverdeada, carac teristicas do tipo de rocha. Frequentemente, seus feldspa tos exibem tonalidades esverdeadas. Os tipos petrográficos mais comuns são granulitos quartzo-feldspáticos; entretanto, granulitos bāsicos, com piroxênios e anfibólios em quantida de considerāvel, aparecem frequentemente, formando intercala ções nos tipos bandados.

Microscopicamente, as associações mineralögicas oḅ servadas são muito variadas e complexas. Predominam textu ras granoblásticas eqüigranulares e xenomörficas. Os princi pais minerais são quartzo e feldspato, este ūltimo exibindo quase invariavelmente intercrescimentos pertíticos, antiper títicos, ou mesopertíticos. o plagioclásio geralmente è an desina, passando a labradorita nos tipos mais bäsicos. In 
tercrescimentos mirmequíticos são comuns. Os minerais escu ros principais são orto e clino piroxênios, hornblenda e bio tita. Em muitos casos, estes dois ültimos minerais perten cem à paragênese primária; em outros casos, provēm da trans formação dos piroxênios.

Muitos granulitos da área apresentam, em adição aos feldspatos com intercrescimentos, certa quantidade de micro clínio, que aparece nas rochas como intersticial, ou substi tuindo parcialmente certos cristais de ortocläsio, denuncian do um fenômeno metamórfico intenso, claramente posterior à formação da paragênese primāria. Este fenômeno mostra-se gradual: em muitas amostras, è apenas incipiente, enquanto que em outras apresenta intensidade suficiente para transfor mar a rocha em um verdadeiro gnaisse granitóide, com vestí gios de uma paragênese primāria de grau mais elevado (restos de piroxênios, ou de mesopertitas). Na Figura 5 foram assí nalados os locais, no interior da região granulitica, onde microclínio foi caracterizado nas lâminas delgadas, em quan tidades apreciāveis. A microclinização, que parece ocorrer em toda a região ocupada pelos granulitos, evidencia duas fases de metamorfismo sucessivas, a primeira en ambiente ca tazonal, e a segunda, de temperaturas e pressões mais baixas, mesozonal.

Vărtas amostras apresentaram sinais de cataclase in tensas, e minerais secundärios tais como clorita, epídoto, fluorita, carbonatos, sericita e outros, característicos de fenômenos hidrotermais de baixa a média temperatura ligados ao cizalhamento. Estas evidências aparecem nas zonas dos grandes fraturamentos assinalados na Figura 5, em especial no mencionado Falhamento de Itapebi, e na outra grande zona de fratura existente ao longo do rio Colônia, entre Potira guã e Itabuna.

Nos arredores da cidade de Salvador, afloram tambëm rochas granulíticas, com caracteres petrogräficos semelhan 
tes aos da região descrita. Nesta ārea são comuns diques de rochas basälticas e/ou piroxeníticas cortando as metamórfi cas regionais. Diques semelhantes foram encontrados tambēm mais para o sul, especialmente na região entre Ilhéus e Cama cã.

Rochas magmäticas, de natureza alcalina, foram assi naladas (Fujimori, 1967; Pedreira et al., 1969) nas proximi dades do rio Pardo, cortando os granulitos regionais. Trata-se de rochas de natureza sienitica insaturada (com nefelina e/ou sodalita). Embora de pequenas dimensões, os corpos in trusivos exibem tipos petrogräficos diferentes, com grandes variações em mineralogia e textura (nefelina-sienitos, soda lita-sienitos, tinguaitos, traquitos, quartzo-sienitos, etc.). As ocorrências principais, assinaladas na Figura 5, são as de Santa Cruz da Vitória, Potiraguá, Itabuna e Itaju de Colo nia. Recentemente foi descoberta nova ocorrência de rochas sieniticas, que formam o maciço de Itarantim, intrusivo nas rochas graniticas que ocorrem a SW do Falhamento de Itapebi.

2 - METASSEDIMENTOS DO GRUPO RIO PARDO

No baixo curso do rio Pardo, na área adjacente à planície costeira, aparecem os metassedimentos estudados por Pedreira et al. (1969). Trata-se de um conjunto constituído originalmente por folhelhos, siltitos, grauvacas, arcózios, conglomerados, e rochas carbonáticas, afetado por metamorfis mo regional de fácies xistos verdes. Os mencionados autores, que denominaram a unidade geotectônica de Grupo Rio Pardo,pu deram reconhecer uma sequência estratigráfica, iniciando-se com rochas mais grosseiras (metaconglomerados da Formação Pa nelinha, ardósias da Formação Camacã, metagrauvacas conglome ráticas da Formação Salobro), continuando com filitos e metas siltitos (Formação Ågua Preta), e terminando com rochas carbonāticas (Formação Serra do Paraíso). 
Petrograficamente, as rochas mais grosseiras apre sentam material detrítico em quantidade considerável, sob for ma de seixos e cristais de quartzo e feldspatos mais ou me nos arredondados, em matriz recristalizada, onde predominam sericita e clorita. Estes dois minerais são os constituin tes essenciais das rochas peliticas, enquanto que calcita e dolomita constituem os märmores da formação de topo. Estrutu ras sedimentares são perfeitamente visiveis nas formações ba sais. Clivagem ardosiana ẻ o caráter predominante nos fili tos da Formação Ågua Preta, enquanto que as rochas carbonāti cas apresentam textura granoblästica, por vezes sacaróide. o conjunto evidencia uma só fase de cristalização orientada, em condições de metamorfismo brando, epizonal.

Os metassedimentos cobrem uma ärea global de $600 \mathrm{Km}^{2}$ e sua estrutura é relativamente simples, do tipo monoclinal, com mergulhos suaves com sentido predominante para $\mathrm{SW}$.

3 - AREA GNAISSICA E GRANITICA MERIDIONAL

Na parte meridional da ärea investigacia, duas gran des unidades litológicas, cujo limite apresenta direção apro ximada $\mathrm{N}^{-\mathrm{S}}$ (Vide Figura 5), puderam ser reconhecidas.

A primeira delas, que ocorre do lado ocidental, é constituída por gnaisses migmatíticos e rochas graníticas di versas, que na região do vale do rio Doce, nos arredores de Governador Valadares, foram descritas por Barbosa et al., (1966).

Estas rochas apresentam-se geralmente bem orienta das, com gnaissificação uniforme e por vezes bandeamento nítí do, caracterizando gnaisses fitados e/ou migmatitos. Rochas graníticas sem orientação visível nos afloramentos aparecem tambēm, com frequência, em associação aos gnaisses e/ou mig matitos.

Ao microscópio, a composição mineralọ̄ica mostrou- 
-se relativamente simples, predominando largamente a associa ção quartzo-microclínio-plagioclāsio (oligoclásio)- biotita. Às vezes, hornblenda tambēm foi encontrada, quase sempre em quantidades inferiores à biotita. A composição global va riou entre granítica e granodioritica, e, de urn modo geral, estas rochas evidenciaram relações texturais indicando um sō estāgio de cristalização orientada e grau de metamorfismo mê dto, dentro do fắcies anfibolito. Tal contexto petrográfico permite correlacionar as rochas em questão com os gnaisses granitóides sintectônicos e com os granitos postectônicos da Serra dos Orgãos, que ocorrem mais para o sul, ao que parece em continuidade física, e que foram objeto de estudo geocro nolögico pormenorizado (Delhal et al., 1969; Cordani et al., 1973 ).

A unidade litológica que ocorre na faixa oriental,e que na região costeira é recoberta por sedimentos neo-Cenozói cos, è formada, essencialmente, por gnaisses kinzigíticos, com grau de metamorfismo mais elevado do que o que afetou a faixa gnáissica descrita pouco antes. Rochas do mesmo tipo aparecem também ao longo do rio Jequitinhonha, entre Itaobim e Salto da Divisa. De modo geral, os gnaisses kinzigiticos apresentam quantidades de biotita inferiores às dos gnaisses migmatíticos normais, de modo que faixas xistosas e/ou con centrações biotîticas são pouco regulares, conferindo àque las rochas aspecto migmatítico difuso, nebulítico. Granada é constituinte normal dos gnaisses kinzigiticos, salientando-se especialmente em algumas intercalações hololeucocráticas, qua se sem biotita.

Microscopicamente, estas rochas apresentam textura granoblāstica xenoblástica e associações mineralógicas do tí po quartzo-plagioclásio - K-feldspato-granada-biotita-cordie rita-sillimanita. Em geral, plagioclāsio (andesina) predomi na sobre o feldspato potássico (ortoclāsio). zntercrescimen tos do tipo antipertita e/ou mesopertita são comuns. Granada 
aparece constantemente, formando porfiroblastos até centimê tricos, englobando outros minerais (quartzo), e conferindo às rochas textura poiquiloblästica. Cordierita aparece com freqtência, em formas lenticulares, exibindo quase sempre in clusões de sillimanita.

A evolução petrogenētica destas rochas não estā clạ ra. Pela sua paragênese, poder-lhe-ia ser atribuido tanto o sub-fäcies mais alto do fácies anfibolito, quanto o próprio fácies granulito. Muitas das amostras estudadas apresentam uma ünica fase de formação de minerais. Entretanto, outras parecem ter sofrido dois eventos metamörficos principais, ten do em vista a existência de restos de piroxênios, ou mesoper titas, que parecem revelar a existência de uma paragênese primāria, formada em condições metamōrficas mais enērgicas. Nücleos granuliticos, revelados pela presença de ro chas caracteristicamente "charnoquiticas", aparecem em cer tas localidades, tais como Barra de são Francisco, ES, ou I tapina, ES, no interior da unidade de gnaisses kinzigiticos. Nücleos semelhantes, porém, podem aparecer tambēm na região de gnaisses migmatíticos, tal como ocorre em Itanhēm, BA, ou em Epaminondas otoni, MG. 
CAPITULO IV

\section{DADOS GEOCRONOLOGICOS}

Do conjunto de amostras disponíveis, foram selecio nadas as mais adequadas para o estudo geocronológico, desen volvido mediante emprego dos métodos $\mathrm{K}-\mathrm{Ar}$ e Rb--Sr. Alguns da dos radiométricos jā existiam antes da realização deste tra balho (Hurley et al., 1967; Cordani et al., 1969; Cordani et al., 1973), e foram incluídos nas interpretações. Os dados analíticos completos (62 determinações pelo método $\mathrm{K}-\mathrm{Ar}$, e 43 pelo método $\mathrm{Rb}-\mathrm{Sr}$ ) encontram-se nos Apêndices 2 e 3 . O Apêndice 1 traz uma descrição petrográfica resumida das amos tras analisadas.

Para o método $\mathrm{Rb}-\mathrm{Sr}$, com duas exceções apenas, as anālises foram executadas em rocha total, e as interpreta ções foram feitas essencialmente mediante emprego de gräfi $\cos$ isocrônicos $\mathrm{Rb}^{87} / \mathrm{Sr}^{86}$ versus $\mathrm{Sr}^{87} / \mathrm{Sr}^{86}$. Cabe aqui lem brar que esta tēcnica é a que permite os resultados mais vâa lidos em termos de evolução geológica sofrida pelo material. Mesmo em rochas policíclicas, é sabido que os isótopos do es trôncio podem se redistribuir durante os eventos mais novos, sem ser perdidos pelo sistema. Portanto, anälises em amos tras representativas da rocha total podem revelar, em condições ideais, inclusive a época da primeira cristalização, o que seria dificilmente possível por anālises Rb-Sr em mine rais separados ou anālises $\mathrm{K}-\mathrm{Ar}$. As idades convencionais $\mathrm{Rb}-$ $-\mathrm{Sr}$, calculadas $\mathrm{com}\left(\mathrm{Sr}^{87} / \mathrm{Sr}^{86}\right)_{i}=0,705$, embora constem do Apêndice 2, praticamente não foram utilizadas neste capítulo, devido ao seu valor interpretativo menor.

Para as determinações pelo método K-Ar, entretanto, foram separados os minerais mais adequados, ou seja micas e 
anfibólios. Quando possivvel, deu-se preferência a estes úl timos, por ser os que possuem melhor retentividade para argô nio, e portanto menos sujeitos a perdas por difusão durante aquecimentos posteriores à sua formação. Entretanto, em cer tas regiões, como no Estado do Espirito Santo, foram encon tradas rochas apresentando biotita como o ünico mineral datá vel pelo método $\mathrm{K}-\mathrm{Ar}$, e presente em quantidades adequadas pa ra a separação. Neste caso as determinações foram efetuadas mesmo sabendo-se, a priori, que os resultados indicariam ape nas a época do ủltimo resfriamento sofrido pelo sistema.

De um modo geral, as determinações $\mathrm{K}-\mathrm{Ar}$ teriam como principal finalidade delimitar a ārea de influência dos fenô menos termo-tectônicos ligados à última orogênese importante ocorrida na região, no final do pré-Cambriano e no início do Paleozóico. Por outro lado, as determinações $\mathrm{Rb}-\mathrm{Sr}$ em rocha total teriam por finalidade situar no tempo alguns eventos de homogeinização isotōpica de Sr, ligados muitas vezes à prōpria formação das rochas.

Os dados radiométricos são comentados a seguir, se parados de acordo com as unidades geológicas ou geotectônicas, a que se referem.

\section{A - Complexo granulitico de Jequié}

Pelo método $\mathrm{Rb}-\mathrm{Sr}$, foram analisadas doze amostras provenientes de oito afloramentos de rochas granuliticas re gionais. Alēm disso, três determinações constantes de traba lhos anteriores, obtidas em duas rochas da região de salva dor, e uma terceira proveniente cos arredores de Cachoeira, tambēm foram incluỉdas nas interpretações. As Figuras 6 , e 7 apresentam várias isōcronas traçadas a partir dos dados mencionados.

As Tabelas 1 e 2 reunem as 22 determinações $\mathrm{K}-\mathrm{Ar}$ disponiveis, sendo 10 da faixa granulítica principal, e 12 


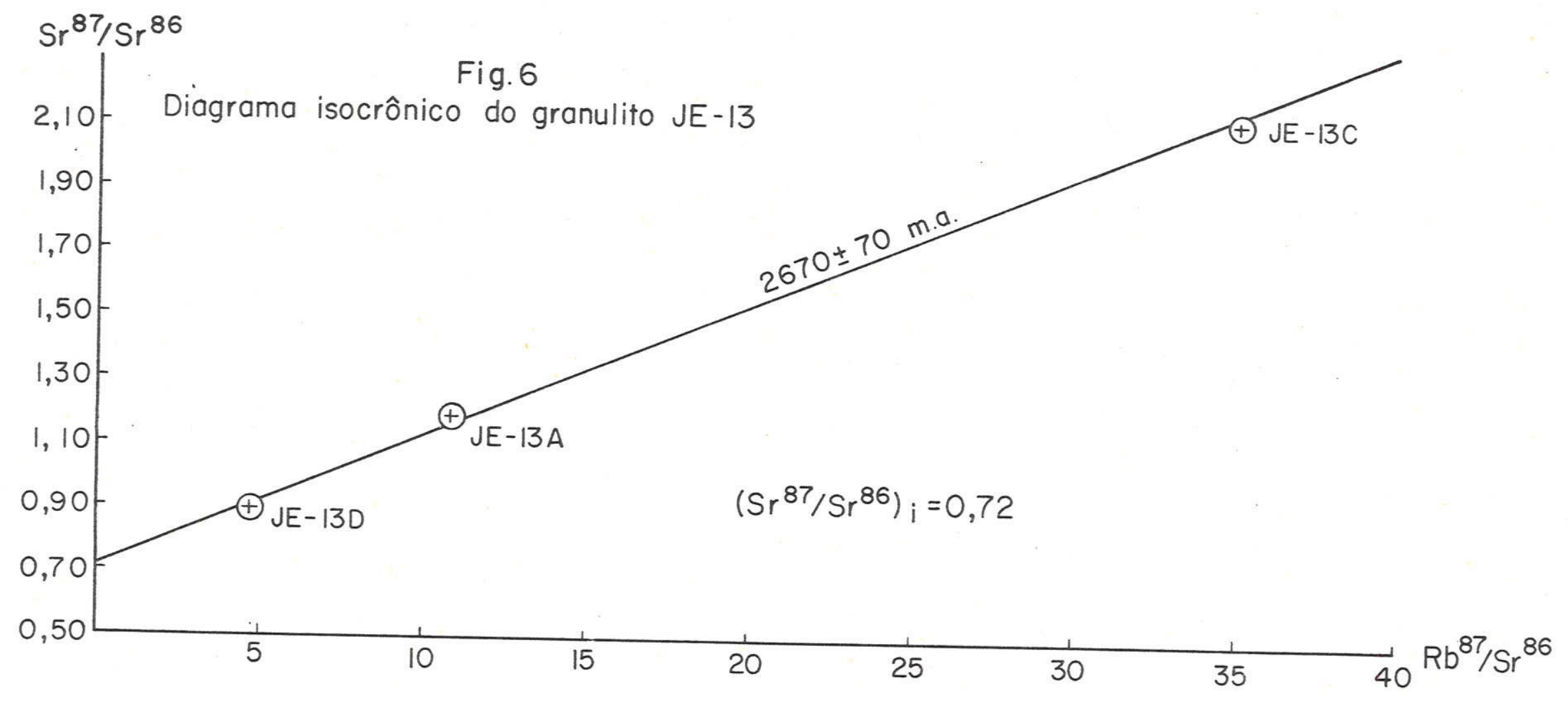


da região de Salvador.

Tendo em vista os dados petrográficos expostos no capítulo anterior, em especial o carāter policíclico de mui tas das rochas granulíticas do Complexo de Jequiēe, o autor resolveu obter um bom número de anälises $\mathrm{Rb}-\mathrm{Sr}$ em rocha to tal, por terem maior valor interpretativo. Idades $\mathrm{K}-\mathrm{Ar}$ fo ram tentadas, sempre que possivel, em anfibólios separados das rochas regionais.

A Figura 6 exibe a isōcrona obtida em três amostras diferentes do granulito ácido JE-13. O bom alinhamento obti do caracteriza uma importante homogeinização isotōpica, que ocorreu provavelmente durante o evento formador dos minerais, na época indicada pela isōcrona ( $2670 \pm 70 \mathrm{m.a.})$. A razão inicial $\mathrm{Sr}^{87} / \mathrm{Sr}^{86}$, próxima de 0,72 , não pode ser considerada anômala, visto que os pontos analiticos estão situados longe da origem, no diagrama isocrônico.

A isócrona I da Figura 7 foi obtida levando-se em conta todas as anālises efetuadas, com exceção das obtidas nas amostras MU-19C, Ped-4, 525, e SA-43D. Trata-se de uma isōcrona de referência, cuja idade $\mathrm{Rb}-\mathrm{Sr}$ de $2610 \pm 60 \mathrm{m.a} .$, é pouco inferior àquela obtida para o granulito ácido JE-13. Estes valores indicam que as rochas granuliticas do Complexo de Jequié teriam sido formadas durante o evento geotectōnico denominado Ciclo orogênico "Guriense", no continente sul-ame ricano.

o autor acredita que o valor da isócrona de referên cia da Figura 7 tenha sido abaixado devido aos efeitos de um rejuvenescimento parcial, acompanhado de saída de estrôncio radiogênico, que teria ocorrido nas amostras SAJ-26, GD-67, SE-46A e $\mathrm{BJ}-10$. As três primeiras (Vide Apêndice 1) são jus tamente as rochas granuliticas analisadas que apresentam maiores quantidades de microclínio em sua composição, tendo sido afetadas, em grande proporção, pelo evento mesozonal posterior à formação dos granulitos. Suas posições no diạ 


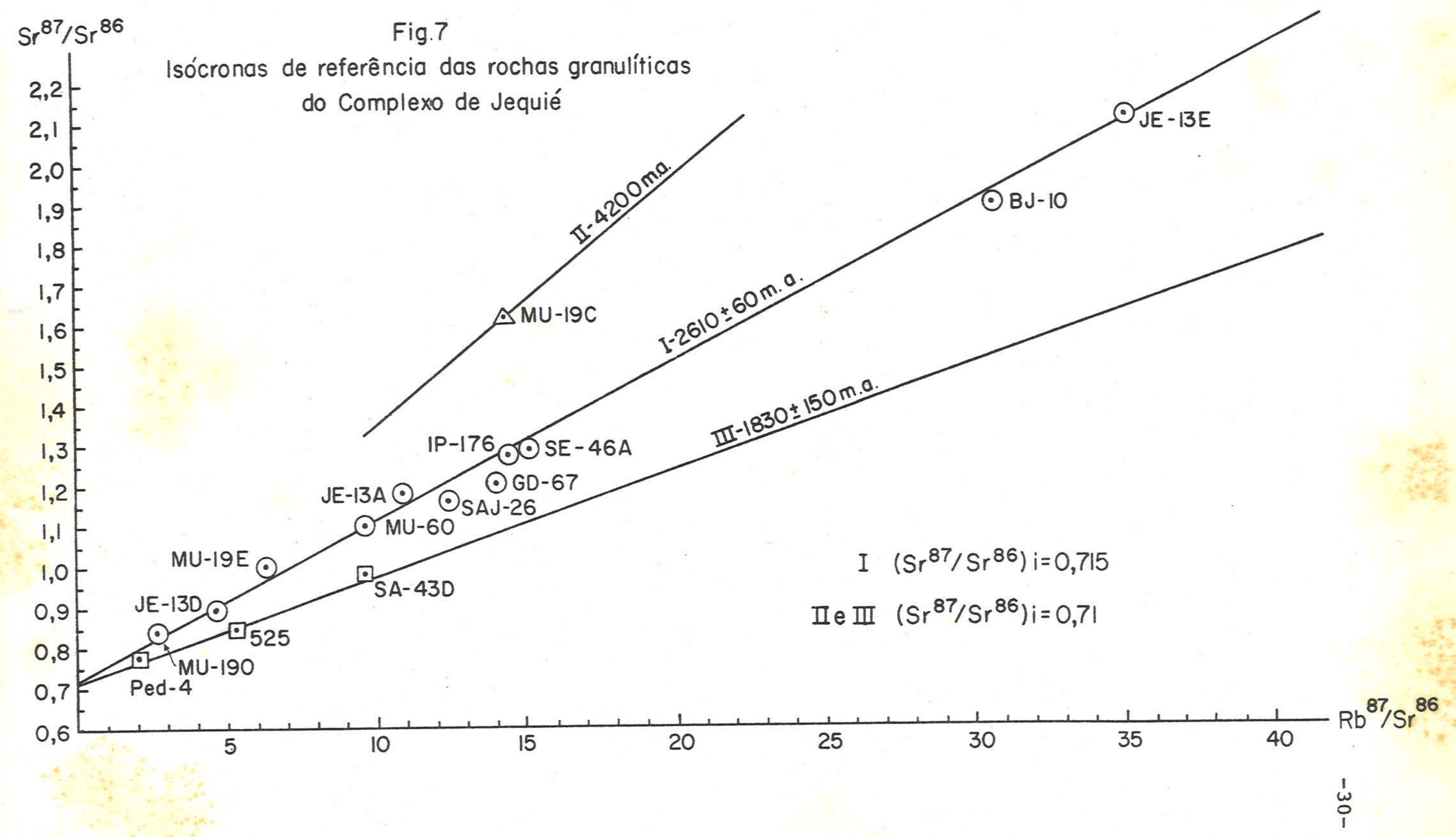


grama isocrônico tendem a diminuir a idade aparente da isöcro na de referência traçada. Deve ser enfatizado, no entanto, que, apesar da microclinização, o rejuvenescimento foi peque no, correspondendo, essencialmente, a uma redistribuição dos isótopos do estrôncio nos sistemas, sem que tenha havido per das consideräveis. A razão inicial $\mathrm{Sr}^{87} / \mathrm{Sr}^{86}$ da isócrona de referência mencionada, de 0,715 , também deve ser considerada normal, tendo em vista que as rochas analisadas possuem valo res elevados do parâmetro $\mathrm{Rb}^{87} / \mathrm{Sr}^{86}$.

Alguns comentārios adicionais fazem-se necessários com relação à posição anômala do ponto analítico MU-19C, que indica uma idade aparente de $4200 \mathrm{~m}$.a. (isócrona II da Figu ra 7). Tal amostra, que foi obtida no afloramento MU-19, re presenta uma banda granulítica escura e maciça. Duas outras amostras do mesmo afloramento situaram-se próximas da isócro na de referência de $2610 \pm 60 \mathrm{~m}$. a. Embora não possa ser excluída a possibilidade de um erro analítico acidental, ou de uma forte modificação no conteúdo de $\mathrm{Rb}$ ou de $\mathrm{Sr}$ durante a evolução geológica sofrida pela rocha, o dado de aproxima

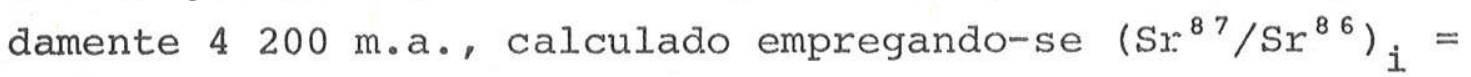
0,705 , poderia indicar a existência de material anterior ao ciclo orogênico de $2700 \mathrm{~m} \cdot \mathrm{a}$. Tal consideração implicaria em que, apesar de ter sido afetado por evento metamórfico dos mais intensos, de caráter catazonal, o sistema conseguiu manter, aproximadamente, suas quantidades originais de estrôn cio 87, permitindo a obtenção da sua idade primäria. Se o dado for confirmado por evidências adicionais, a rocha MU-19 seria a mais antiga encontrada, atē o momento, no continente sul-americano.

Na Figura 7 foram também colocados os pontos analí ticos de três rochas analisadas no MIT, e que indicariam uma isōcrona de referência de $1830 \pm 150 \mathrm{~m} \cdot \mathrm{a}$. (isōcrona III). Tal valor parece indicar que as rochas com idades próximas a $2700 \mathrm{~m} . \mathrm{a}$. terminam antes da região de Cachoeira, de modo que 
- embasamento das bacias sedimentares de Tucano e do Recônca vo, bem como a região de Salvador, podem representar äreas siálicas formadas durante o Ciclo Trans-Amazônico, o que já havia sido assinalado por Hurley et $a$ l. (1967), e por Cordani et ar. (1969).

Uma anälise dos resultados obtidos pelo método $\mathrm{K}-\mathrm{Ar}$ (Tabelas 1 e 2) parecem corroborar a grande influência regio nal dos eventos deste ciclo. Apenas dois resultados $\mathrm{K}$-Ar, no anfibólio da amostra JE-50, e na biotita da amostra F-48, apresentaram valores próximos da idade da isōcrona $\mathrm{Rb}-\mathrm{Sr}$ em rocha total dos granulitos de Jequié.

Vārias análises apresentadas na Tabela 1 apresentam resultados da ordem de 1700 - 1900 m.a., correspondendo a eventos de resfriamento relativos ao ciclo Trans-Amazônico. Por causa disto, é bem possível que sejam relativos a este ciclo os fenômenos de microclinização que afetaram as rochas granuliticas formadas anteriormente em ambiente catazonal.

A região de Salvador merece uma análise particular. As rochas granulíticas que lá ocorrem parecem ter-se formado durante o ciclo Trans-Amazônico (isócrona III da Figura 7), e - resfriamento regional posterior aos eventos deste ciclo te

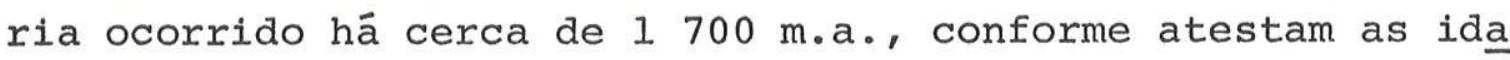
des aparentes das amostras 10a-B-66, R-Verm-1 e Salv.-5. Vá rios diques básicos cortam a região, e não sofreram qualquer metamorfismo posterior à sua formação. Suas idades aparen tes $\mathrm{K}-\mathrm{Ar}$ deveriam ser, portanto, inferiores a $1700 \mathrm{~m} . \mathrm{a}$.,épo ca do resfriamento regional. Efetivamente, quase todas as amostras datadas incluem-se no intervalo 1300 - 1730 m.a., com uma exceção representada pelo resultado da amostra R-Verm-la (2 050 m.a.). Esta determinação foi obtida em ro cha total, em material parcialmente alterado, e o presente autor considera possível a presença de excesso de argônio nos seus minerais secundārios, causando uma idade $\mathrm{K}$-Ar anômala.

A interpretação dos resultados $\mathrm{K}-\mathrm{Ar}$ das rochas ba 
TABELA 1 - IDADES K-Ar DE ROCHAS DO COMPLEXO GRANULITICO DE JEQUIE

\begin{tabular}{|c|c|c|c|c|c|}
\hline AMOSTRA & ROCHA & MATERIAL & NO LAB (SPK) & IDADE $\mathrm{K}-\mathrm{Ar}$ & $\left(x 10^{6}\right.$ \\
\hline $\mathrm{AP}-\mathrm{X}$ & Anfibólio gnaisse & Anfibölio & 1557 & 991 & \pm 30 \\
\hline$F-48$ & Granulito ácido & Biotita & 780 & 2459 & \pm 80 \\
\hline$I L-11$ & Granulito básico & Biotita & 2283 & 1726 & \pm 64 \\
\hline ITB -88 & Anfibolito & Anfibólio & 1841 & 1769 & \pm 55 \\
\hline ITJ-46 & Granulito bāsico & Ānfibólio & 1969 & 1891 & \pm 91 \\
\hline ITJ-62A & Granulito básico & Anfibólio & 1970 & 672 & \pm 12 \\
\hline$J E-23$ & Granulito básico & Anfibólio & 1953 & 997 & \pm 16 \\
\hline $\mathrm{JE}-50$ & Granulito básico & Anfibölio & 2212 & 2850 & \pm 300 \\
\hline$J E-70$ & Granulito băsico & Anfibólio & 1964 & 1786 & \pm 49 \\
\hline$V Q-412 B$ & Granulito básico & Anfibōlio & 2311 & 1520 & \\
\hline
\end{tabular}


TABELA 2 - IDADES K-Ar DE ROCHAS DA REGIÂO DE SALVADOR

\begin{tabular}{|c|c|c|c|c|c|c|c|c|}
\hline AMOSTRA & ROCHA & MATERIAL & NO LAB (SPK) & IDADE & $\mathrm{K}-\mathrm{Ar}$ & $(x$ & $10^{6}$ & anos) \\
\hline FB-3 & Piroxenito & Rocha total & 2609 & & 1314 & \pm & 26 & \\
\hline ONDINA-2 & Diabāsio & Rocha total & 2612 & & 1731 & \pm & 34 & \\
\hline ONDINA-2a & Diabāsio & $\begin{array}{l}\text { Rocha total } \\
\text { Plagioclásio }\end{array}$ & $\begin{array}{l}2627 \\
2467\end{array}$ & & $\begin{array}{l}1449 \\
1587\end{array}$ & $\begin{array}{l} \pm \\
\pm\end{array}$ & $\begin{array}{l}20 \\
18\end{array}$ & \\
\hline R.VERM-I & Granulito básico & $\begin{array}{l}\text { Plagioclásio } \\
\text { Biotita }\end{array}$ & $\begin{array}{l}2586 \\
2600\end{array}$ & & $\begin{array}{l}1714 \\
1541\end{array}$ & $\begin{array}{l} \pm \\
\pm\end{array}$ & $\begin{array}{l}16 \\
15\end{array}$ & \\
\hline R.VERM-la & Diabásio & Rocha total & 2610 & & 2052 & \pm & 21 & \\
\hline$S A L V-A$ & Diabāsio & Rocha total & 2606 & & 1366 & \pm & 14 & \\
\hline$S A L V-B$ & Diabāsio & $\begin{array}{l}\text { Rocha total } \\
\text { Plagioclásio }\end{array}$ & $\begin{array}{l}2578 \\
2581\end{array}$ & & $\begin{array}{l}1653 \\
1330\end{array}$ & $\begin{array}{l} \pm \\
\pm\end{array}$ & $\begin{array}{l}15 \\
14\end{array}$ & \\
\hline SALV -5 & Granulito básico & Biotita & 2305 & & 1678 & \pm & 40 & \\
\hline $10 a-B-66$ & Granulito básico & Biotita & 726 & & 1705 & \pm & 48 & \\
\hline
\end{tabular}


sälticas de Salvador ē ulteriormente complicada pelo fato de não serem concordantes os resultados provenientes dos dife rentes materiais da mesma rocha (caso das amostras ONDINA $2 a$ e SALV-B). Em virtude da possibilidade da ocorrência de â gônio em excesso nos minerais secundārios, as anālises obti das em minerais separados (plagioclāsios) devem merecer maior confiança. Assim, na falta de melhores evidências, se rá considerado o intervalo $1300-1600 \mathrm{~m} . \mathrm{a}$. como sendo épo ca de tectonismo importante, para a região de Salvador. Cabe assinalar que esta è a primeira vez que é demonstrada a exis tência de vulcanismo basăltico do pré-Cambriano, na região oriental da Plataforma Brasileira.

värios resultados $k-A r$ revelam a influência de tẹ tonismos posteriores à formação das rochas, capazes de provo car escape de argônio em determinados sistemas, o que parece ter ocorrido com as amostras JE-23, ITJ-62A e AP-X. Esta $\overrightarrow{\mathrm{I}} 1$ tima situa-se na região de importante falhamento, que passa próximo de Itabuna. Idades aparentes mais jovens do que se ria de esperar, tais como as obtidas no anfibölio da amostra VQ-412 B, ou na biotita da amostra R.Verm-1, podem ser atri buídas a perdas de argônio causadas pelo aquecimento sofrido durante a intrusão dos diques de diabāsio que ocorrem nas proximidades dos locais onde ambas as amostras foram colhi das.

\section{$B$ - Metassedimentos do Grupo Rio Pardo}

No caso dos metassedimentos do Grupo Rio Pardo, cin co amostras de rochas filiticas, relativamente ricas em rubi dio, foram analisadas em rocha total, pelo método $\mathrm{Rb}-\mathrm{Sr}$. Uma delas $(B A-69-13 A)$ pertence à Formação Camacã de Pedreira et al. (1969), e as restantes à Formação Água Preta. Duas de las tambëm tiveram suas idades aparentes determinadas pelo mētodo $\mathrm{K}-\mathrm{Ar}$, em rocha total, e uma terceira, de mármore com 
flogopita, fol analisada em duplicata. A Tabela 3 reune os dados $\mathrm{K}$-Ar obtidos, enquanto que a Figura 8 apresenta as isó cronas de referência traçadas a partir dos dados $\mathrm{Rb}-\mathrm{Sr}$.

As idades aparentes $\mathrm{K}$-Ar mostram-se concordantes, dentro do erro experimental, indicando como regionalmente significativa a idade de $470 \mathrm{~m} . \mathrm{a} .$, época em que os sistemas fecharam-se em relação à difusão de argônio. Na opinião do autor, tal fato, ligado ao abaixamento da temperatura nos sistemas, estaria associado ao levantamento epirogenētico da ärea, ocorrido em época posterior ao metamorfismo epizonal regional.

A isócrona de referência II da Figura 8 representa a melhor reta que se ajusta aos cinco pontos analiticos $\mathrm{Rb}-$ -Sr, e indica uma idade de $470 \pm 50 \mathrm{~m} . \mathrm{a}$. , concordante com os valores $\mathrm{k}$-Ar. Tal isócrona exibe um valor elevado para razão inicial $\left(\mathrm{Sr}^{87} / \mathrm{Sr}^{86}\right)_{i}=0,724$, o que indica que pode ter decorrido um importante intervalo de tempo entre a depo sição dos sedimentos e o fechamento dos sistemas à difusão de estrôncio.

Desprezando-se o ponto analitico da amostra BA-69-8, os quatro pontos restantes definem uma segunda isócrona de referência (isōcrona I na Figura 8), que apresenta idade de $630 \pm 170 \mathrm{~m} . \mathrm{a} .$, e razão inicial $\mathrm{Sr}^{87} / \mathrm{Sr}^{86}=0,708$. A exclu são da amostra Ba-69-8, embora subjetiva, parece justificā vel visto que o ponto analítico situa-se em posição aparen temente anômala em relação aos demais, e tende a diminuir a inclinação da isōcrona de referência, baixando sua idade aparente.

O valor obtido para a isócrona I pode representar o evento metamórfico sofrido pelos sistemas, desde que não te nham ocorrido modificações importantes nas concentrações de $\mathrm{Rb}$ e de $\mathrm{Sr}$ das quatro amostras. Nesta interpretação, na amos tra BA-69-8 teria ocorrido sensivel entrada de $\mathrm{Rb}$, ou saída 
TABEIAA 3 - IDADES K-AR DOS METASSEDIMENTOS DO GRUPO RIO PARDO

\begin{tabular}{|c|c|c|c|c|}
\hline AMOSTRA & ROCHA & MATERIAI & NQ IAB (SPK) & IDADE $K-A r\left(x 10^{6}\right.$ \\
\hline $\mathrm{CA}-18$ & Filito & Rocha total & 1834 & $471 \pm 30$ \\
\hline CÃ -39 & Filito & Rocha total & 1835 & $501 \pm 45$ \\
\hline GB-CAI & Mármore & Flogopita & $\begin{array}{c}1831 \\
2332(1831 R)\end{array}$ & $\begin{array}{l}494 \pm 35 \\
527 \pm 50\end{array}$ \\
\hline
\end{tabular}




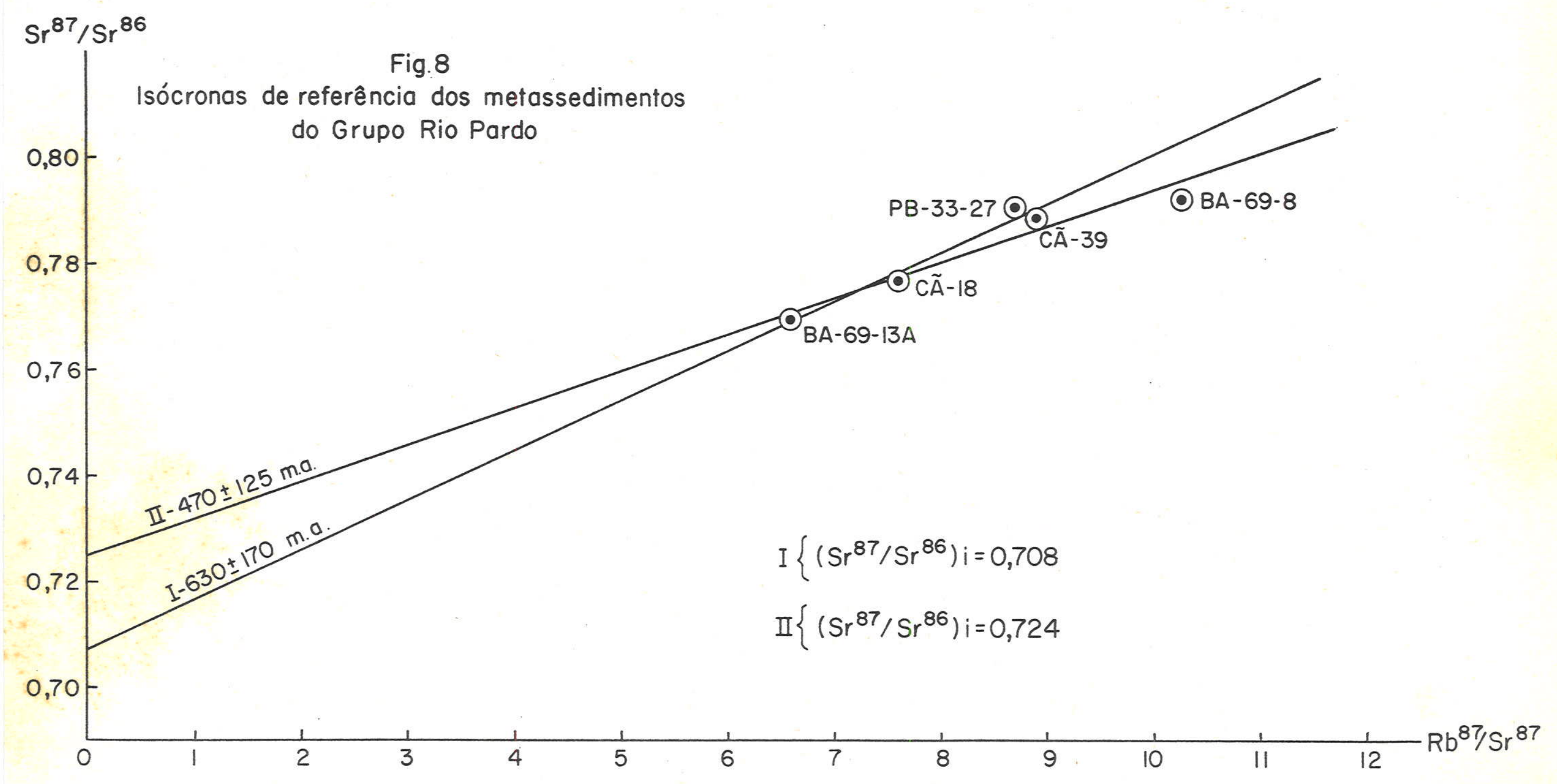


de $\mathrm{Sr}$ radiogênico, entre a ëpoca do evento metamórfico e a época do resfriamento regional. A relativa dispersão dos pontos em relação à isōcrona I poderia indicar diferenças originais nas relações iniciais $\mathrm{Sr}^{87} / \mathrm{Sr}^{86}$ de cada sistema, em virtude de quantidades variāveis de material detrítico.

Uma explicação alternativa para as idades aparentes $\mathrm{K}-\mathrm{Ar}$, bem como os dados Rb-Sr obtidos, em especial o da amos tra BA-69-8, seria a de imaginar um evento inicial (630 m.a.), durante o qual formou-se a paragênese metamōrfica principal dos metassedimentos, seguido por um tectonismo importante (470 m.a.), durante o qual ocorreu escape de argônio e aber tura parcial dos sistemas para a difusão do estrôncio.

C - Rochas gnäissicas da região de Itapebi

Por pertencerem à região do falhamento de Itapebi, considerado de importância fundamental na evolução geológica

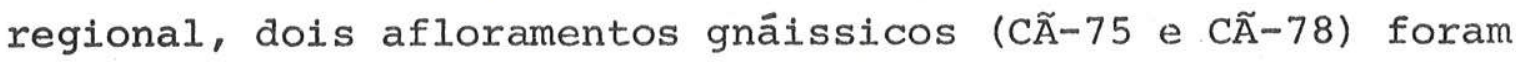
objeto de estudo pormenorizado pelo método $\mathrm{Rb}-\mathrm{Sr}$, enquanto que uma terceira amostra (CÃ-81) foi analisada pelo método $\mathrm{K}-\mathrm{Ar}$. As Figuras 9 e 10 reunem os dados Rb-Sr obtidos.

Os quatro pontos analíticos relativos às amostras do gnaisse fitado CÃ-78 não exibiram bom alinhamento ( Figu ra 9), fato que pode ser relacionado com homogeinização iso tópica inicial incompleta, ou com perturbações posteriores. os retângulos da figura são referentes aos intervalos dos erros experimentais de cada análise. Nota--se que a isócrona traçada consegue com dificuldade passar pelos quatro retângu los, e sua idade, de $795 \pm 200 \mathrm{~m}$.a. pode ser completamente desprovida de significação. De melhor qualidade parecem ser os dados obtidos levando-se em conta as seis análises, o que

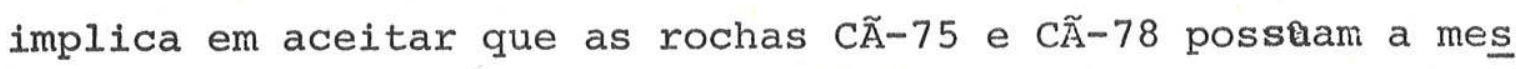
ma evolução geológica. Neste caso, os pontos analíticos

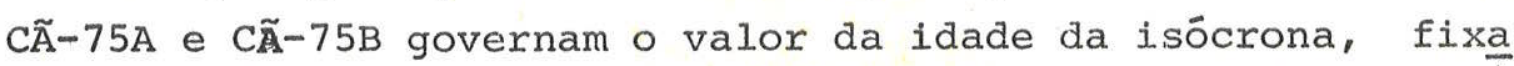




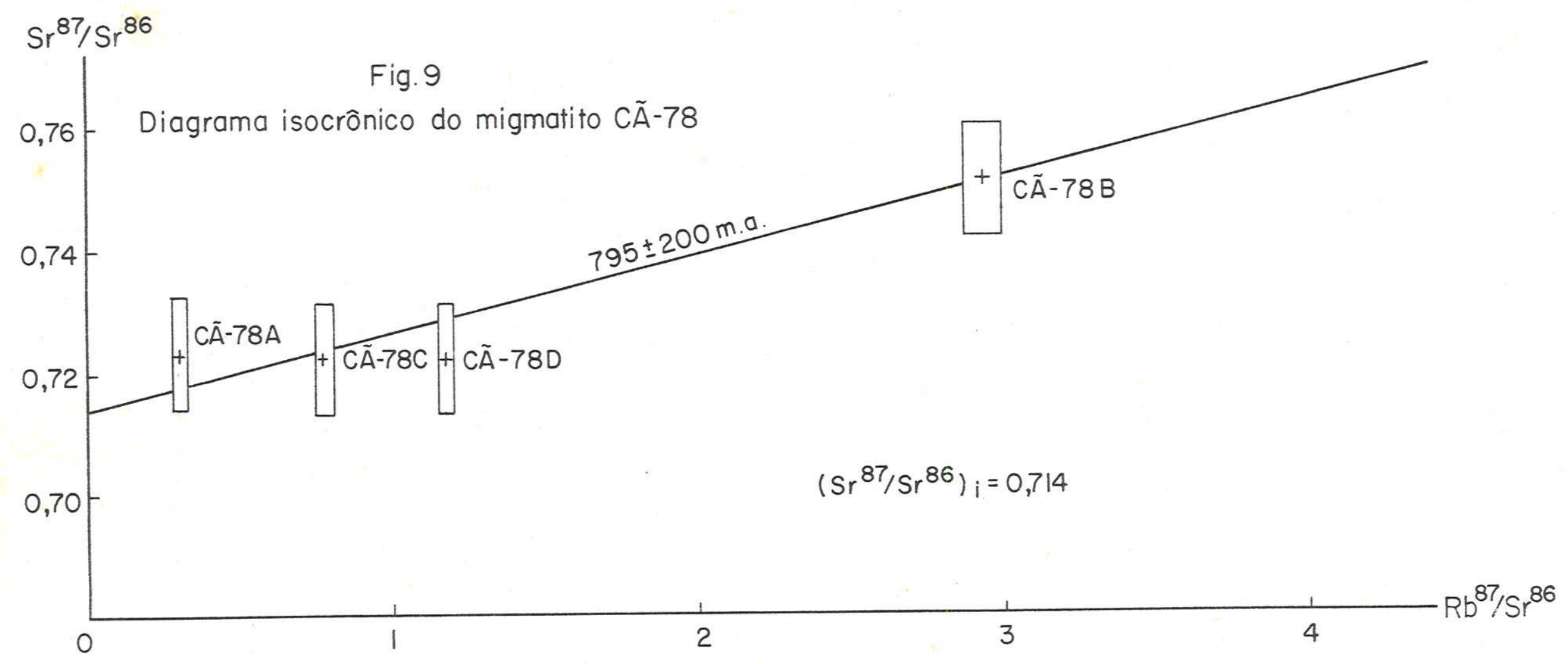




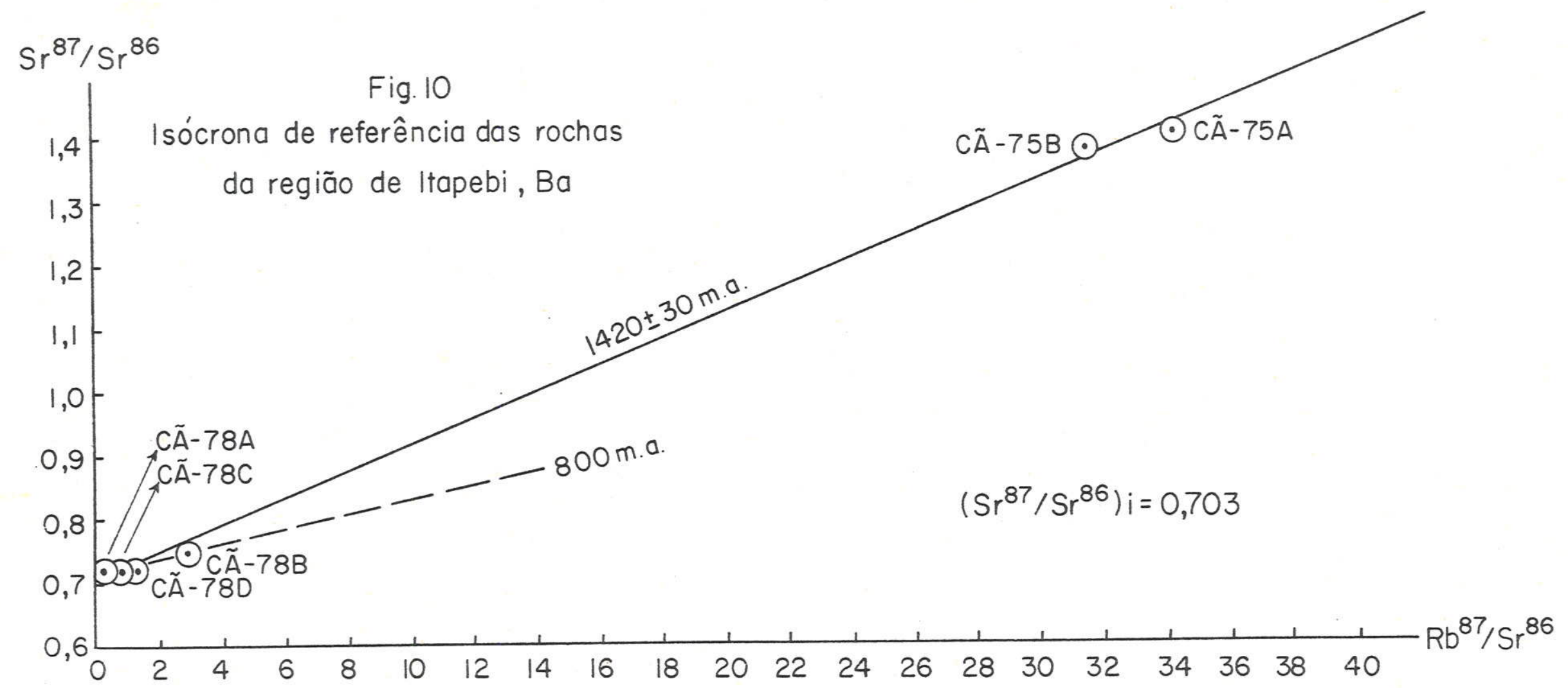


do em $1420 \pm 30 \mathrm{~m} . \mathrm{a}$. (Figura 10).

Com relação ã determinação $\mathrm{K}-\mathrm{Ar}$ efetuada, a idade aparente do anfibólio da amostra C $\tilde{A}-81$, de $554 \pm 32 \mathrm{~m} \cdot \mathrm{a}$. (vi de Tabela 4), representa a fase de resfriamento regional em que a temperatura caiu abaixo do limite de retenção de argô nio pelo mineral, que deve ser da ordem de $450-500^{\circ} \mathrm{C}$.

Considerando o conjunto dos dados disponíveis, ē possivel que o evento indicado pela isōcrona da Figura 10 , de aproximadamente $1420 \mathrm{~m} . \mathrm{a}_{\text {. , seja significativo, e corres }}$ ponda à ëpoca real de formação das rochas analisadas.os even tos associados ao falhamento, e à formação de minerais de baixa temperatura, tais como fluorita, epỉdoto e sericita,po deriam ser os causadores das perturbações químicas responsâ veis pelo mau alinhamento dos pontos analiticos das amostras C $\tilde{A}-78 A, B, C$ C D.

\section{D - Rochas graniticas e gnäissicas do sul da Bahia, leste de Minas Gerais e norte do Espirito Santo}

Os gnaisses kinzigiticos que ocorrem na faixa cos teira entre Vitōria e Porto Seguro, cuja evolução petrogenē tica não é completamente esclarecida, foram objeto de estudo geocronológico pelo método $\mathrm{Rb}-\mathrm{Sr}$ em rocha total. Das nove amostras analisadas, oito aparecem na Figura 11, onde foram também incluídos os pontos analíticos relativos a duas amos tras caracteristicas da unidade granïtica (ITA-122 e 76). As Tabelas 4 e 5 reunem as 28 determinações $\mathrm{K}$-Ar obtidas em to da a região meridional do trabalho, que incluem o dado rela tivo à amostra C̃̃-81, jā comentado anteriormente.

A dispersão dos pontos analíticos ē flagrante, na

Figura 11. No cálculo da isócrona de referência obtida, que apresentou idade de $550 \pm 80 \mathrm{~m}$. a. , e razão inicial $\mathrm{Sr}^{87} / \mathrm{Sr}^{86}$ $=0,722$, foi excluído o ponto relativo à amostra CASC-A (da dos analíticos no Apêndice 2). A inclusão de tal ponto ana. lítico no cálculo da isócrona de referência, por causa de 


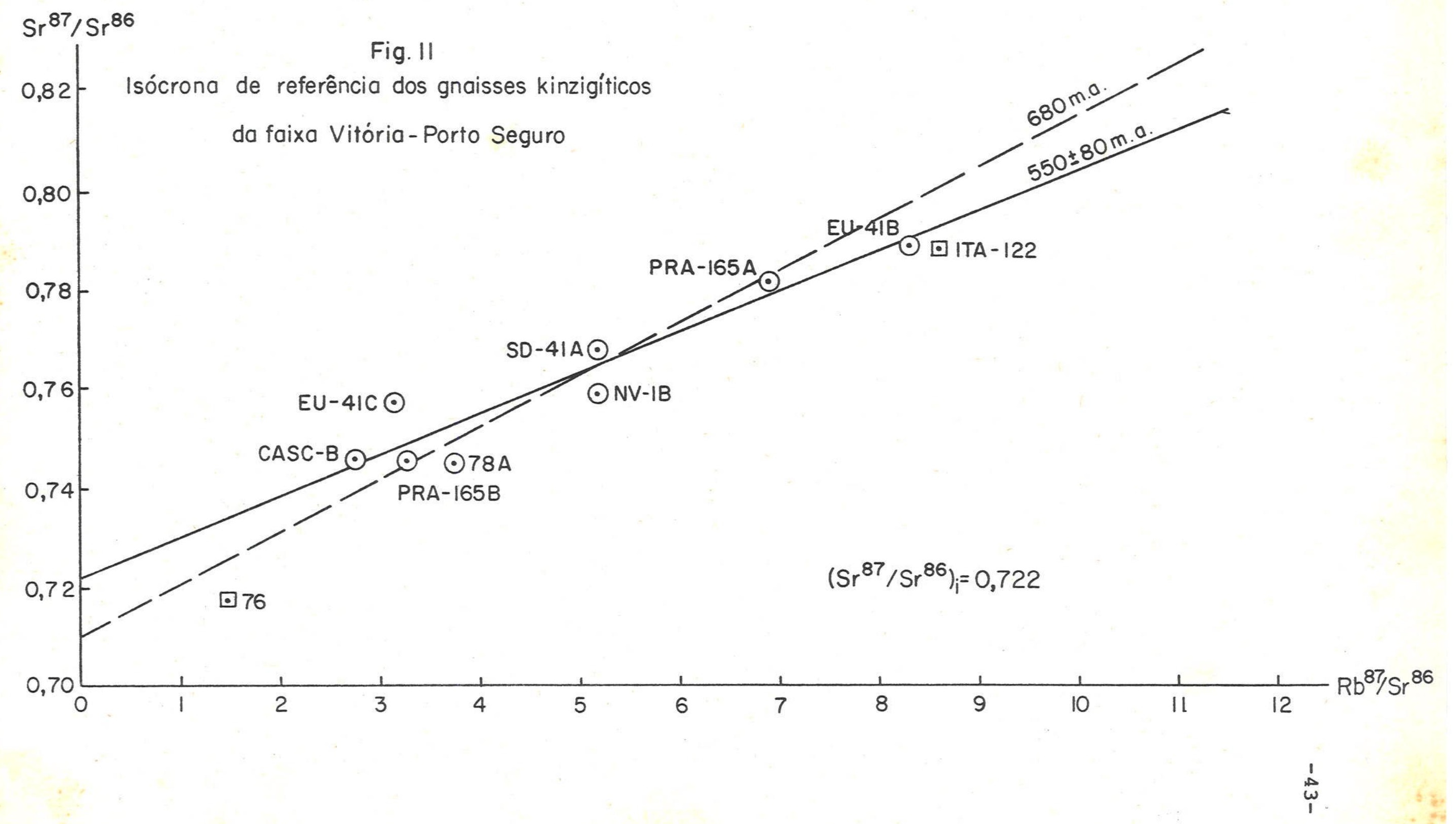


sua elevada razão $\mathrm{Rb}^{87} / \mathrm{Sr}^{86}$, em relação aos demais, tenderia a abaixar o valor da idade obtida.

Poucas informações seguras resultam da análise da Figura 11. De inicio, cabe assinalar que a dispersão dos pontos pode sex originada por razões iniciais $\mathrm{Sr}^{87} / \mathrm{Sr}^{86}$ dife rentes, para cada sistema, na ëpoca da homogeinização isotō pica regional, que ocorreu sem düvida durante o Ciclo orogê nico Brasiliano. A seguir, o valor "médio" encontrado para esta razão inicial $\left(\mathrm{Sr}^{87} / \mathrm{Sr}^{86}=0,722\right)$ indica que as rochas já possuiam evolução crustal anterior, na época da homogeini zação.

Verifica-se tambëm que a isöcrona de referência tra çada é muito influenciada pelos pontos analíticos referentes às amostras EU-4IB e EU-41C, situados um de cada lado da re ta. Se tais amostras não haviam alcançado eqlijiłbrio na sua composição isotópica, como o presente autor acredita, o vâ lor da isōcrona de referência é incorreto e inferior à idade real da homogeinização dos sistemas. Assim, torna-se suges tivo o fato de que a reta que une os pontos PRA-165A e PRA-165B (amostras de gnaisses kinzigiticos típicos, do mesmo afloramento) indica uma idade de $680 \mathrm{~m} . \mathrm{a}$. , e uma razão ini cial $\mathrm{Sr}^{87} / \mathrm{Sr}^{86} \cong 0,71$ (vide reta tracejada na Figura 11 ). E possivel que este dado melhor represente a época de formação das rochas kinzigiticas.

Com relação às rochas graníticas, que ocupam prefe rencialmente a faixa mais interna, jä no Estado de Minas Ge rais, somente duas amostras foram analisadas pelo mëtodo $\mathrm{Rb}-$ -Sr em rocha total, visto que tais rochas são quase certamen te extensão das que ocorrem na Serra dos Orgãos mais para o sul, que foram objeto de estudo geocronológico pormenorizado (Cordani et al., 1973). Os dois pontos analiticos foram in cluidos na Figura 11, e pode ser observado que ambos situam-se pouco abaixo, mas próximos da isócrona de referência de $550 \mathrm{~m} . \mathrm{a} .$, o que confirma a filiação das respectivas rochas 
ao Ciclo Brasiliano. Uma das duas anālises (amostra 76) faz parte do conjunto estudado por Cordani et al. (1973).

Quase todas as idades $\mathrm{K}-\mathrm{Ar}$ obtidas na ärea em ques tão (Tabelas 4 e 5) incluem-se no intervalo 430-550 m.a. Os resultados referem-se ao ültimo resfriamento sofrido pelos diversos sistemas, e são característicos de eventos termi nais do Ciclo Brasiliano.

Somente três amostras apresentaram idades aparentes pouco mais antigas; a tremolita da rocha ALM-104C (700 m.a.), e duas biotitas, das rochas $\operatorname{co}-53$ ( 716 m.a.) e VI-28 $(670 \mathrm{m.a.})$.

De um modo geral, os valores relativos às três deter minações efetuadas em anfibölios (amostras ALM-104B, CÃ-81, CB-43-34, e ITA-104, Tabela 4) são pouco mais antigos do que os obtidos em micas, o que está de acordo com um padrão de resfriamento regional onde os anfibólios começam a reter ar gônio antes do que as micas. Deve ser notado também que os valores relativos ao Ciclo Brasiliano aparecem independente mente do tipo de rocha analisado, e inclusive em algumas amostras de rochas provavelmente formadas em época anterior, como parece ser o caso do xisto AIM-104B, do granulito bási co VI-176A, ou dos gnaisses kinzigiticos com mesopertita e/ /ou hiperstênio M-Pa, CASC-B e NV-126. O autor considera que nestas rochas deve ter ocorrido rejuvenescimento total a partir de material pré-existente, durante o Ciclo Brasilia no, enquanto que nas amostras já referidas que exibem idades aparentes pouco mais antigas (ALM-104C, CO-53 e VI-28), pare ce evidente um fenômeno de rejuvenescimento parcial, em sí tuação semelhante.

As idades mais baixas, próximas a $450 \mathrm{~m} . \mathrm{a}$. (Eo-Paleo zóico), obtidas nas micas, representam a época em que a tem peratura regional caiu abaixo de $200-250^{\circ} \mathrm{C}$, devido ao levan tamento epirogenético que sucedeu à orogênese do final do pré-Cambriano. 
TABELA 4 - IDADES K-Ar DE ROCHAS DA REGIÃO SUL DA BAHIA E NORDESTE DE MINAS GERAIS

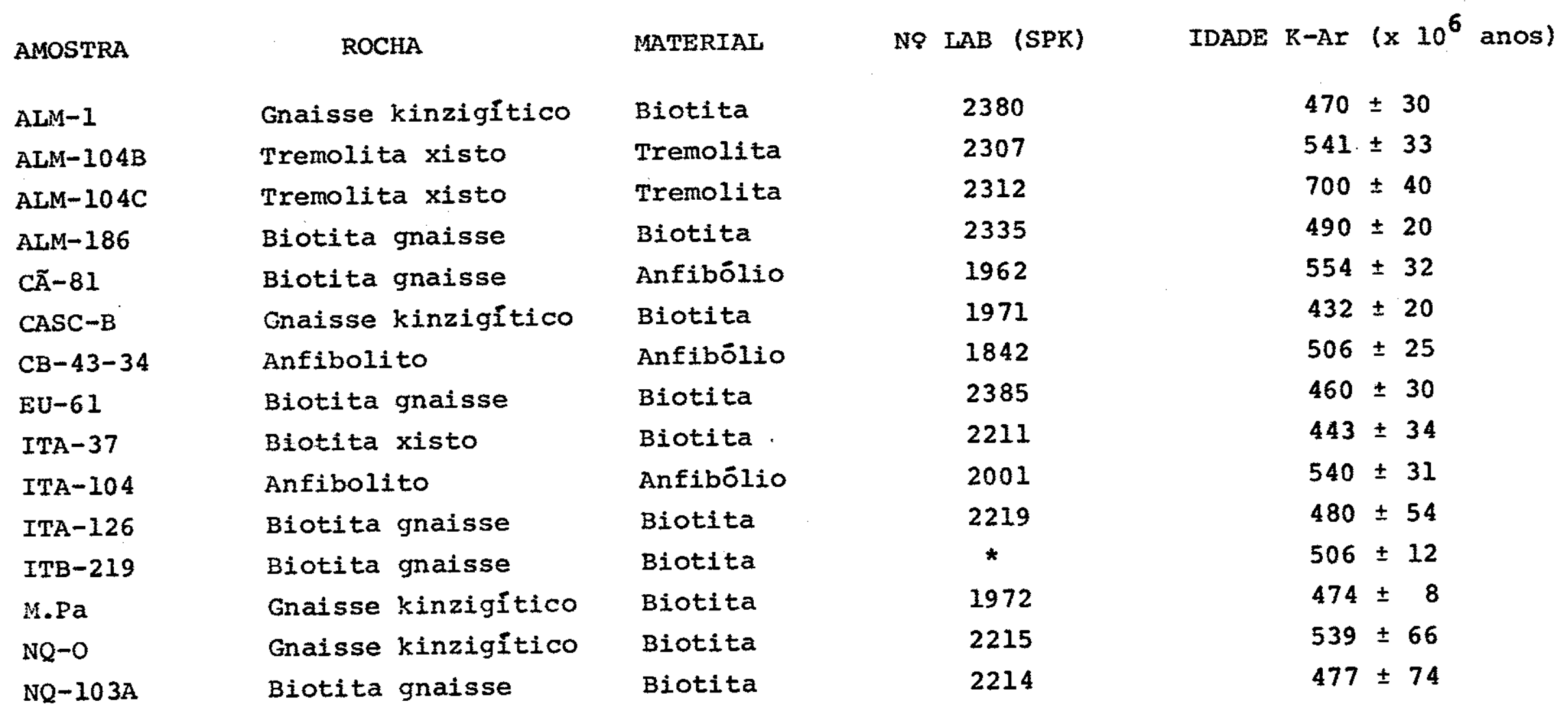

* 15 determinações, valor médio. 
TABELA 5 - IDADES K-AY DE ROCHAS DA REGIÃO LESTE DE MINAS GERAIS E ESPIRITO SANTO

\begin{tabular}{|c|c|c|c|c|c|c|c|}
\hline AMOSTRA & $\mathrm{ROCHA}$ & MATERIAI & No & LAB (SPK) & IDADE K-Ar & $\left(x 10^{6}\right.$ & anos) \\
\hline $\mathrm{CO}-53$ & Biotita gnaisse & Biotita & & 2359 & 716 & \pm 10 & \\
\hline $\mathrm{co}-66$ & Gnaisse kinzigitico & Biotita & & 2394 & 451 & \pm & \\
\hline $\mathrm{CO}-120$ & Biotita gnaisse & Biotita & & 2356 & 447 & \pm & \\
\hline GOV-68 & Pegmatito & Muscovita & & 2231 & 480 & \pm 8 & \\
\hline $\mathrm{GOV}-98$ & Gnaisse kinzigitico & Biotita & & 2384 & 452 & \pm & \\
\hline GOV-208 & Gnaisse kinzigitico & Biotita & & 2221 & 472 & \pm 28 & \\
\hline$N V-126$ & Gnaisse kinzigitico & Biotita & & 2395 & 450 & \pm 7 & \\
\hline PINHEIRO & Gnaisse kinzigítico & Biotita & & 2222 & 509 & \pm 12 & \\
\hline$V I-28$ & Gnaisse kinzigítico & Biotita & & 2355 & 670 & \pm 10 & \\
\hline$V I-62 A$ & Biot.-Horn. gnaisse & Biotita & & 2383 & 458 & \pm 6 & \\
\hline$V I-103$ & Biotita gnaisse & Biotita & & 2358 & 449 & \pm 5 & \\
\hline$V I-176 \mathrm{~A}$ & Granulito básico & Biotita & & 2360 & 492 & \pm 10 & \\
\hline $78 a$ & Gnaisse kinzigitico & Biotita & & 1192 & 475 & \pm 38 & \\
\hline
\end{tabular}


o padrão geocronológico existente leva a correlacio nar a região aqui investigada com a que ocorre mais para o sul, e situada em continuidade estrutural. Assim, os gnais ses graniticos da faixa interior podem ser considerados equi valentes à Formação Serra dos Orgãos, e formados durante o Ciclo Brasiliano, enquanto que os gnaisses kinzigíticos são aqui correlacionados com as rochas da Formação Paraíba do Sul, formada durante o Ciclo Trans-Amazônico, mas rejuvenes cida durante o Ciclo Brasiliano. Entretanto, os dados não permitem excluir a hipótese de que, pelo menos em parte, es tes gnaisses kinzigiticos representem material formado no próprio Ciclo Brasiliano, e metamorfoseado em grau mais ele vado do que os gnaisses graníticos da Formação Serra dos orgãos.

\section{E - Rochas intrusivas alcalinas do sul do Estado da Bahia}

As rochas sieniticas que ocorrem no sul da Bahia me receram atenção especial, por causa da importante situação tectônica que evidenciam. Seis amostras, quatro delas pro venientes de um mesmo maciço, foram analisadas pelo método $\mathrm{Rb}-\mathrm{Sr}$, e os dados obtidos serviram para a construção da Figu ra 12. Em adição, nove análises pelo método $\mathrm{K}$-Ar também fo ram efetuadas, e os resultados encontram-se na Tabela 6 .

As amostras de sienitos com sodalita do afloramento BA-69-17 mostraram-se muito favorāveis para datação $\mathrm{Rb}-\mathrm{Sr}$, por possuirem elevadas razões $\mathrm{Rb}^{\text {tot } / \mathrm{Sr}}{ }^{\text {tot }}$. A isócrona traça da pelos quatro pontos analiticos ( $A, B, C, F)$ exibe um im portante evento de homogeinização isotópica, com idade de $665 \pm 25 \mathrm{~m}$.a. e razão inicial $\mathrm{Sr}^{87} / \mathrm{Sr}^{86}=0,712$. As idades convencionais das três amostras mais ricas em rubỉio (A, B,

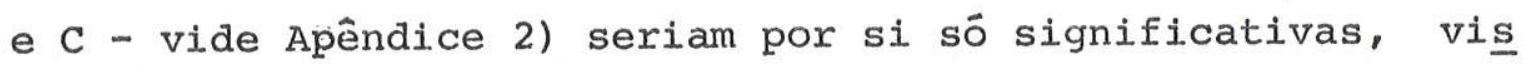
to que os resultados praticamente independem de variações na razão inicial $\mathrm{Sr}^{87} / \mathrm{Sr}^{86}$. Na mesma figura foram colocados os 


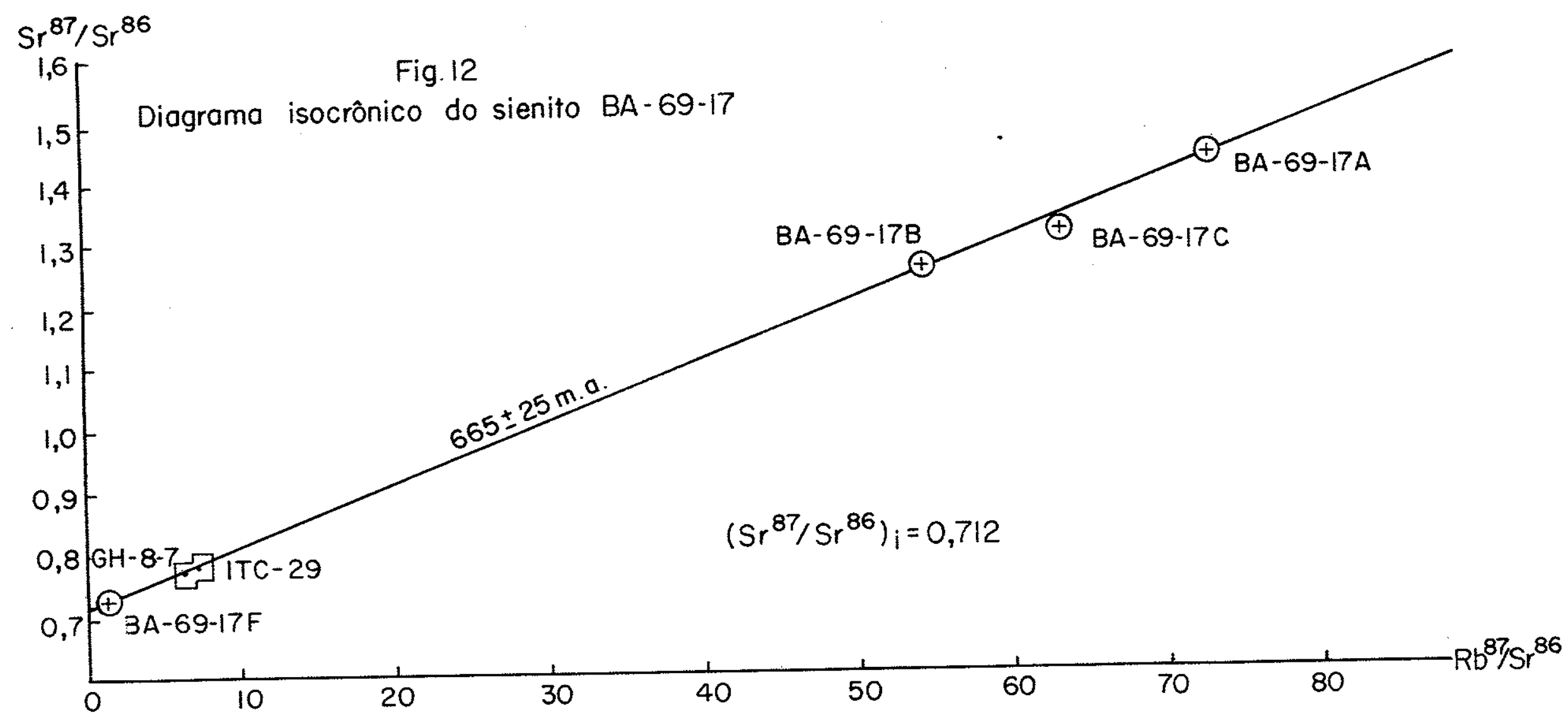


pontos analíticos relativos às amostras ITC-29 e GH-8-7, e sua posição,praticamente sobre a isöcrona, parece demonstrar que elas participaram do mesmo evento de homogeinização iso tōpica.

O conjunto de dados obtidos pelo método $\mathrm{K}$-Ar (Tabe la 6), mostra-se heterogêneo, como já havia sido observado por Cordani et al. (1969).

Três resultados, sendo dois obtidos em anfibólio (POTIG-3 e S-88-A) e o terceiro na mesma sodalita que partici pa da isócrona Rb-Sr (BA-69-17F), evidenciam idades aparen tes superiores a $700 \mathrm{~m} . \mathrm{a}$. Não hã sinais que possam levar à suspeita de excesso de argônio nos materiais, visto que an fibölios são normalmente isentos de tal inconveniente, en quanto que sodalita ainda não foi suficientemente investigado pelo método K-Ar. Além disso, a concordância obtida nas idades aparentes dos anfibólios, aliada à reconhecida reten tividade para argônio destes minerais leva à sugestão de que a idade de cerca $765 \mathrm{~m}$. a. seja próxima da época de formação dos maciços sieníticos. Esta interpretação implica em consi derar o evento de homogeinização isotópica de estrôncio $(665$ m.a.) como tendo ocorrido em temperatura inferior ao li mite de retentividade de argônio pelo retículo dos anfibó lios, estimado em $450-500^{\circ} \mathrm{C}$.

Os demais resultados $\mathrm{K}-\mathrm{Ar}$ devem ser relacionados com etapas de resfriamento regional. E interessante obsex var os valores discordantes obtidos pelos dois métodos na ro cha total GH-8-7 (Rb-Sr com 610 m.a. e K-Ar com 460 m.a.); isto mostra que o argônio é perdido pelo sistema a temperatu ras superiores aos limites de retentividade dos diversos mi nerais, enquanto que o estrôncio pode sofrer redistribuição entre as diversas fases, mas è retido na rocha total. Outro dado interessante é a constatação de diferentes graus de re tentividade para argônio em variedades do mesmo mineral (so dalita branca com idade aparente maior do que sodalita cin zenta da mesma localidade). 
TABELA 6 - IDADES K-Ar DE ROCHAS ALCALINAS DO SUL DO ESTADO DA BAHIA

\begin{tabular}{|c|c|c|c|c|c|c|}
\hline AMOSTRA & ROCHA & MATERIAL & NO IAB (SPK) & IDADE $K-A r$ & $\left(x 10^{6}\right.$ & anos) \\
\hline$B A-69-17 F$ & Veio de sodalita & Sodalita (branca) & 2487 & 727 & \pm 11 & \\
\hline $\mathrm{BA}-69-17 \mathrm{G}$ & Veio de sodalita & Sodalita(cinza) & 2489 & 517 & \pm 46 & \\
\hline $\mathrm{GH}-8-7$ & Traquito & Rocha total & 1836 & 460 & \pm 10 & \\
\hline$I T-5$ & Sienito & Biotita & 762 & 556 & \pm 20 & \\
\hline ITAR-2, 3 & Sienito & Biotita & 2628 & 469 & \pm 14 & \\
\hline POTIG-1 & Sienito & Biotita & 1562 & 424 & \pm 35 & \\
\hline POTIG-3 & Sienito & Anfibólio & 1049 & 765 & \pm 40 & \\
\hline$S-70-A$ & Sienito & Biotita & $156^{\circ}$ & 411 & \pm 35 & \\
\hline$S-88-A$ & Sienito & Anfibölio & 1056 & 766 & \pm 40 & \\
\hline
\end{tabular}


Na interpretação do autor, do conjunto de dados dis ponível, a idade das intrusões sieniticas seria maior, ou no máximo igual a $765 \mathrm{~m} . \mathrm{a}$., e os sistemas teriam sofrido homo geinização isotópica importante durante a fase principal do Ciclo orogênico Brasiliano. Isto explicaria c fato das ro chas sieníticas não terem sido encontradas, até o momento, cortando os metassedimentos do Grupo Rio Pardo.

Alēm disso, as idades aparentes das biotitas das ro chas POTIG-1 e S-70A (vide Tabela 6) sïo ainda menores do que a época de resfriamento regional, ocorrido por volta de $470 \mathrm{~m} . \mathrm{a} .$, segundo as determinações obtidas nos próprios me tassedimentos (vide Tabela 3 ). Tal anomalia pode ser atri buída à situação tectônica das duas amostras em questão,pró ximas do falhamento de Itapebi, bem como do falhamento ao longo do rio Colônia. Importantes movimentos nestas duas zo nas de fraqueza tectônicas, provavelmente ativas durante o início do Paleozóico, seriam responsáveis por perdas de a gônio pelas biotitas analisadas. 
CAPITULO $V$

EVOLUÇAOO GEOLOGICA REGIONAL

Os dados geocronológicos comentados no capítulo ante rior demonstram o caräter polimetamörfico de grande parte das rochas regionais. Foram registrados eventos metamörficos re lacionados com värios ciclos orogênicos, bem como fenômenos anorogênicos, associados a importantes tectonismos de fratura.

\section{A - Ciclo orogênico Guriense}

o evento geotectônico mais antigo, que afetou grande parte das rochas do Complexo de Jequié è o que foi definido, na notícia explicativa sobre a carta tectônica do Brasil (Fe reira, 1972) como Ciclo Guriense, de idade próxima a

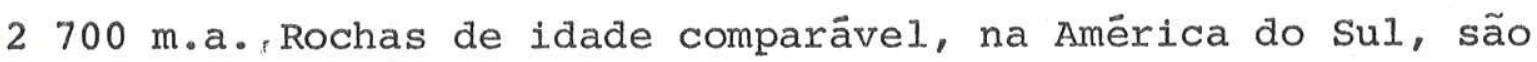
encontradas no Escudo das Guianas, onde a unidade tecto-orogê nica foi definida, e em algumas regiões da parte oriental da plataforma Brasileira, como no Complexo de Bação, Quadrilátero Ferrifero, MG (Herz, 1970), ou na serra da Mantiqueira, MG (Cordani et al., 1973).

No caso do Complexo de Jequiē, a região formada ou afetada pelo Ciclo Guriense apresenta direções estruturais prōximas de $\mathrm{N}-\mathrm{S}$, e suas paragêneses primărias revelam um epí sōdio metamörfico de alto grau, de fácies granulito.

Um único resultado, obtido na rocha granulítica MU-19, parece indicar a existência de material formado anteriormente, que não foi rejuvenescido, apesar da intensidade dos agentes metamórficos. Se tal dado vier a ser confirmado, ficaria de monstrada a existência de um embasamento siálico, com idade da ordem de 4200 m.a., para a unidade geotectônica Guriense. 
B - Ciclo orogênico Trans-Amazônico

O ciclo Trans-Amazônico, com idades características

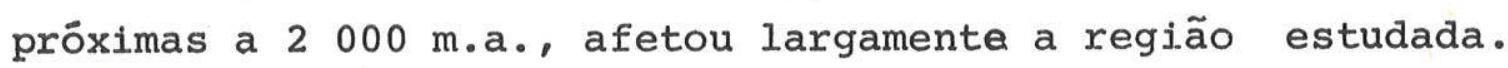
Um cinturão pertencente ao ciclo parece existir na região ad jacente ao Complexo granulítico de Jequiē, a nordeste e a leste da mencionada unidade, tendo em vista as idades $\mathrm{Rb}-\mathrm{Sr}$ em rocha total coletadas por Cordani et al. (1969).

As rochas Trans-Amazônicas, nas regiões de Salvador e de Cachoeira, também apresentam grau de metamorfismo eleva do, de fäcies granulito. Suas direções estruturais N-S e NW-SE permitem inferir que o cinturão provavelmente se pro longa para o norte, constituindo o embasamento da bacia de Tucano e aparecendo, em fácies mesozonal, na região de Uauá. As rochas epizonais que constituem a Serra de Jacobina jā fo ram apontadas por Cordani et al. (1969) como pertencentes ao Ciclo Trans-Amazônico. Se esta interpretação estiver corre ta, estaria evidenciada a polaridade orogênica do cinturão, com rochas epizonais do lado oeste, mesozonais na parte cen tral, e catazonais a leste. O ante-pais da unidade de $2000 \mathrm{~m} . \mathrm{a}$. estaria situado do lado ocidental.

Fenômenos importantes de rejuvenescimento das ro chas do Complexo de Jequiē foram atribuídos ao Ciclo Trans-Amazônico, e o aparecimento de microclínio foi considerado como indicador de processo metamórfico de condições mesozo nais. Assim, a região hoje exposta teria constituído a infraestrutura da unidade geotectônica de 2000 m.a.

O conjunto de rochas metamórficas descritas acima teria sofrido uma fase de soerguimento, acompanhado de ero são intensa, e da ascensão de rochas formadas em profundida de até os nỉveis superiores da crosta. Tal fenômeno, de es cala regional, acarretou o súbito resfriamento dos sistemas, e ocorreu há cerca de 1700 m.a., como parecem demonstrar as idades aparentes $\mathrm{K}-\mathrm{Ar}$ em micas, esparsas em toda a região. 
Alēm disso, tais resultados indicam que, salvo fenômenos lo cais, a unidade não sofreu ulteriores aquecimentos importantes.

A idade aparente $\mathrm{K}-\mathrm{Ar}$ da biotita da rocha $\mathrm{F}-48$, um granulito äcido dos arredores de Camacã, indica que o comple xo de Jequië, nesta região, chega praticamente à costa, de vendo o cinturão Trans-Amazônico situar-se mais para leste, talvez na região da plataforma continental. Esta unidade posivelmente reaparece mais para o sul, se for correta a correlação indicada neste trabalho, entre os gnaisses kinzi gỉticos da faixa Vitória-Porto Seguro e a Formação Paraíba do Sul, que possui cerca de $2000 \mathrm{~m} . \mathrm{a}$. (Cordani et al., 2973). Como jä foi mencionado no capítulo anterior, é dificil apon tar a idade real das rochas kinzigiticas, tendo em vista a intensidade dos fenômenos metamörficos sofridos pela área, du rante o final do prë-Cambriano. Neste trabalho, o autor emi te a hipótese da existência de um cinturão orogênico de ida de Trans-Amazônica ao longo da atual costa brasileira, cujo ante-pais estaria situado do lado ocidental, e representado pelo Complexo de Jequiē, a norte, e pelos gnaisses Mantiquei ra, a sul.

\section{C - Eventos intermediärios, entre os Ciclos Trans-Amazônico e Brasiziano}

Entre 1300 e 1600 m.a., na região de Salvador, 으 correram importantes atividades tectônicas, às quais associa ram-se rochas vulcânicas anorogênicas de natureza basāltica. Tais fenômenos talvez sejam o reflexo, sobre uma região cra tônica, de esforços de natureza orogênica ocorridos, na mes ma ëpoca, em āreas adjacentes à unidade estável. Esta espe culação deriva da existência de um número considerável de idades aparentes da ordem de 1300 - 1400 m.a., que parecem estar relacionadas com eventos geológicos reais, formadores de rochas, em diversas localidades. De inicio, o evento re 
presentado na Figura 10, relativo aos gnaisses de Itapebi, no lado sul da unidade. A seguir, o evento descrito por Tavora et al. (1967) referente à região central da Bahia, e caracte rizado, com dūvidas, como "Ciclo Espinhaço". Finalmente, os resultados referentes ao alto estrutural Pernambuco-Alagoas, que separa o geossinclínio Sergipano da ārea orogênica Cari riana, que indicam uma isōcrona de referência de 1400 m.a. (B.B.Brito Neves, comunicacão verbal). E possivel que uma quantidade maior de dados geocronológicos à disposição venha a permitir a caracterização de um ciclo orogênico intermediä rio, entre o Trans-Amazônico e o Brasiliano, formado por fai xas de dobramentos que circundam a unidade estável desde 1700 m.a., já descrita, e que talvez incluam os Grupos Mi nas e Espinhaço, mais para o sul. Ferreira (1972) indica, en tre os maiores eventos geotectônicos para a América do sul, um "Ciclo Minas-Uruaçuano", com $900-1300$ m.a., e um "Ci clo Espinhaço", com 1300 - I $800 \mathrm{~m} . \mathrm{a}$. Entretanto, o presen te autor considera que os dados geocronológicos disponiveis, no momento, ainda são insuficientes para uma caracterização mais precisa dos eventos geotectônicos intermediārios entre os Ciclos Trans-Amazônicos e Brasiliano.

Segundo a interpretação aventada no capitulo ante rior, outro importante fenômeno tectônico não orogênico te ria ocorrido na parte meridional do complexo de Jequié: a in trusão das rochas alcalinas sieniticas, ao que parece ao lon go de uma zona de fraturamento de direção NE-SW. Este magma tismo seria anterior a $760 \mathrm{m.a.,}$ e portanto, mais antigo do que a fase principal do Ciclo Brasiliano, a julgar pelas de terminações de idade $\mathrm{K}$-Ar obtidas em alguns anfibölios.

D - Ciclo orogênico Brasiliano

A influência do Ciclo orogênico Brasiliano, cujos eventos situam-se entre 650 e $450 \mathrm{~m} . \mathrm{a} .$, è muito intensa na 
região estudada, especialmente em sua parte meridional. Tra ta-se dos fenômenos relativos a importante faixa de dobramentos denominada Ribeira (Almeida et al., no prelo), que estende- se para o sul, ao longo da costa da América do Sul, atē o Uruguay.

Esta faixa de dobramentos, ativa no final do pré-Cambriano e no inf́cio do Paleozóico, delimita-se pelo Falha mento de Itapebi com o Complexo granulítico de Jequiē. E fla grante a diferença no padrão geocronológico dos lados $\mathrm{NE} e$ SW do referido falhamento: quase todas as rochas analisadas, do lado meridional, foram formadas ou rejuvenescidas no $\mathrm{C}$ i clo Brasiliano.

Os metassedimentos do Grupo Rio Pardo, cujo embasa mento è representado por rochas granulíticas antigas, pare cem ser vestigios de material formado durante o Ciclo, no fi nal do pré-Cambriano, preservados por tectonismo. Trata-se, provavelmente, de sedimentos de para-plataforma, pouco modifi cados pelos processos metamórficos que afetaram a faixa de dobramentos a sW, na ārea adjacente.

Na região estudada, a unidade geotectônica Brasilią na expõe, essencialmente, a sua infra-estrutura, que sofreu intenso metamorfismo mesozonal. Neste aspecto, a unidade po de ser correlacionada com a Formação Serra dos orgãos, a qual parece evidenciar continuidade fisica com os granitos, gnaí ses graníticos e migmatitos da região de Governador Valada res. Tais rochas continuam rumo nordeste, até Salto de Divi sa, onde as direções estruturais sofrem uma inflexão para NW (Vide Figura 5). Analogamente ao caso dos gnaisses sin tectônicos da serra dos orgãos, o autor acredita que a unida de, de natureza granitica, tenha sido realmente formada no Ciclo Brasiliano, por anatexia de material do próprio cintu rão orogênico, ou palingênese (e/ou granitização) de mate rial da infra-estrutura. 
A inflexão apontada das estruturas para NW, a partir da região de Salto da Divisa, leva a influência do Ciclo Bra siliano atë as regiões de Caculē, Paramirim, Brotas de Macau bas, e explica as determinações $\mathrm{K}-\mathrm{Ar}$ encontradas por Tavora et al. (1967), em sua grande maioria referentes ao intervalo 450 - $650 \mathrm{~m}$. a. A caracterização desta faixa como sendo reju venescida no Ciclo Brasiliano permite separar em duas partes - Craton do são Francisco (Almeida, 1967): uma delas, que in clui a ärea de ocorrência do Grupo Bambui em Minas Gerais, pá ra a qual neste trabalho é mantida a denominação original; a segunda, que inclui a chapada Diamantina na Bahia, para qual este autor propõe a denominação "Craton de Salvador".

A supraestrutura da faixa de dobramentos Ribeira, apa rece em certas regiões, como nos estados de são Paulo e Para ná (Grupo Açungui), onde a situação parece indicar a existên cia de ante-pais para noroeste. A mesma polaridade è indica da pelo grau de metamorfismo alcançado pelos gnaisses kinzigí ticos da faixa Vitória-Porto seguro (entre es fácies anfiboli to e granulito), visto que rochas granïticas, de fácies mais baixo, ocorrem a oeste. E necessärio lembrar que, embora as rochas kinzigiticas sejam neste trabalho consideradas como formadas no Ciclo Trans-Amazônico, o evento metamórfíco que evidenciam (Figura 11) è de idade Brasiliana.

Pela sua posição tectônica, em discordância sobre as estruturas do Espinhaço, e pelo seu baixo grau de metamorfis mo, é possỉvel que os metassedimentos atribuídos ao Grupo Ma caubas da região do rio Araçuai (MG) tambëm representem a su praestrutura, pouco dobrada e pouco metamórfica, da unidade geotectônica Brasiliana. Finalmente, as coberturas de platá forma estável, atribuỉdas ao Ciclo Brasiliano, estão represen tadas pelos sedimentos, por vezes epimetamórficos, do Grupo Bambui, em Minas Gerais.

Ao longo de toda a faira de dobramentos Ribeira, o pađrão geocronológico parece ser uniforme. Assim, para a evo 
Iução da unidade, o exemplo melhor estudado ë o do Grupo Açun gui (Cordani e Bittencourt, 1967; Cordani e Kawashita, 1971). Tais autores indicam a época de $650 \mathrm{~m} . a$. como a fase sintectô nica principal da unidade, $540 \mathrm{~m} . \mathrm{a}$. como a fase póstectônica mais importante, e $450-500 \mathrm{~m} . \mathrm{a}$. como a época do levantamen to da cadeia montanhosa, acompanhada da formação de depōsitos pös-orogênicos, e do resfxiamento regional. Tal evolução è aqui extrapolada para a região objeto do presente trabalho, visto que os dados obtidos não fogem do padrão esperado. E especialmente interessante o valor encontrado nas idades apa rentes $K$-Ar das micas, entre 450 e $470 \mathrm{~m} . a$. , com impressionan te regularidade.

- falhamento de Itapebi representa uma feição tectô nica certamente ativa durante o Ciclo Brasiliano. Os movimen tos ao longo da zona de fraqueza podem ter-se iniciado antes, mas os eventos principais foram provavelmente sincrônicos com os da fase sintectônica do cinturão Brasiliano (cerca de $650 \mathrm{m.a.).} \mathrm{A} \mathrm{natureza} \mathrm{inicial} \mathrm{do} \mathrm{falhamento} \mathrm{è} \mathrm{aqui} \mathrm{considera}$ da como sendo de empurrão, com o bloco SW cavalgado sobre 0 bloco NE. Atualmente, a superficie de erosão encontra-se em um nĩvel que não permite a observação direta de feições topo gráficas associadas ao possivel empurrão. Entretanto, pode ser verificado que o elemento tectônico coloca lado a lado ro chas presumivelmente da mesma idade (por exemplo, as rochas graniticas de Salto da Divisa e os metassedimentos do Grupo Rio Pardo), mas formadas em profundidades diferentes, na cros ta terrestre. A zona tectônica pode ter sido reativada em outras ocasiões, apōs a sua formação, sendo que movimentos pós-Brasilianos são evidenciados pelas idades aparentes de 410$430 \mathrm{~m} . \mathrm{a}$. obtidas nas biotitas dos maciços alcalinos de potira guá (Vide Tabela 6).

Uma hipötese menos tradicional sobre a evolução geo lögica regional pode ser avançada, se os dados forem conside rados no contexto da tectônica global. Analisando apenas os 
dobramentos Brasilianos, o padrão por eles exibido poderia ter sido formado durante a colisão de duas paleo-placas no final do pré-Cambriano, ambas portadoras de crosta siálica. Tais regiões corresponderiam aos Cratons de Salvador e do São Francisco, denominados pouco antes. Esta hipötese, embo ra tenha forte carāter especulativo, permitiria explicar a existência dos intensos dobramentos ocorridos na faixa entre as duas unidades cratônicas, sem que possa ser caracteriza do um geossinclinal típico, de idade Brasiliana. As gran des zonas de falhamentos de empurrão (Cordilheira do Espi nhaço a $W$, e Falhamento de Itapebi, a E), que afetam inclu sive o Grupo Bambui, tambëm seriam facilmente explicadas.

Este modelo, que implica em considerar a existência de grandes movimentos horizontais, no pré-Cambriano, poderia ser testado atravēs de medidas paleomagnēticas. Para tal, seria necessário obter amostras adequadas, de rochas forma das em épocas anteriores à suposta colisão entre as paleo-placas, e pouco perturbadas tectonicamente. Alëm disso,pa ra uma anâlise completa dos dados paleomagnēticos, seria condição necessäria obter medidas em rochas mais ou menos contemporâneas, e situadas sobre todas as unidades que se deslocaram relativamente. E possivel que alguns dos metas sedimentos do Grupo Rio Pardo, certas rochas do Grupo Bam bui na Bacia de Lençois e no Estado de Minas Gerais,algumas rochas da Formação Estância (SE) e talvez alguns dos metas sedimentos da região do rio Araçuai (MG) possam satisfazer as condições mencionadas para a execução do teste sugerido.

- Eato de imaginar as duas massas siálicas referi das aproximando-se, no final do prë-Cambriano, destruiria algumas das correlações aventadas nos capitulos anteriores. Por exemplo, os metassedimentos do Grupo Rio Pardo não fa riam parte da faixa de dobramentos Ribeira, e os granulitos de Salvador, dependendo da posição da zona de sutura ("suture belt"), não seriam parte da mesma unidade geotectô 
nica que a Formação Paraỉba do sul.

$E$ - Sintese de evolucão geolögica regional

Resumindo, serão relacionados a seguir os principais eventos geológicos da faixa costeira oriental Brasileira, en tre salvador e vitória:

$4200 \mathrm{m.a}$. (?) - Formação de algumas rochas na ārea de Mutui pe, BA.

$2700 \mathrm{m.a}$ - Ciclo orogênico Guriense. Formação das ro chas granuliticas do Complexo de Jequiē.

$2000 \mathrm{~m} \cdot \mathrm{a}$. - Ciclo orogênico Trans-Amazônico. Formação das rochas granuliticas de Salvador e Ca choeira, e dos gnaisses kinzigiticos. Fenô menos de rejuvenescimento no complexo de Je quiē.

$1700 \mathrm{m.a}$ - Tërmino da cratonização e resfriamento do craton de salvador.

1300 - 1600 m.a. - Vulcanismo basältico na região de Salvą dor. Formação das rochas gnäissicas da Re gião de Itapebi (Ciclo Espjnhaço ?).

$760 \mathrm{m.a}$ - Intrusões alcalinas no sul da Bahia.

$650 \mathrm{~m} . \mathrm{a}$ - Ciclo orogênico Brasjiliano. Metamorfismo epizonal do Grupo Rio Parđo. Formação das rochas gnāissicas mesozonais da faixa inter na. Rejuvenescimento total das rochas kin zigiticas costeiras.

Movimentação principal no falhamento de Ita pebi.

450 - 500 m.a. - Término da cratonização e resfriamento da parte oriental da Plataforma Brasileira. 
CAPITULO VI

CORRELAÇOES COM O PADRÃO GEOCRONOLÓGICO DA ĀFRICA EQUATORIAL

Neste capítulo será tentada uma comparação da evolü ção geológica prë-cambriana da região oriental brasileira com a da região africana que the teria sido adjacente, segun do as reconstruções que levam em conta a deriva dos continen tes. Esta correlação será necessariamente esquemätica, ten do em vista a heterogeneidade dos dados disponiveis.

A Figura 13 mostra as principais unidades geotectôn cas, nos dois continentes, justapostos segundo a reconstru ção de Buzlard et al. (1965). Para simplificar o desenho, são aqui mantidas apenas as linhas de costa, algumas das co ordenadas atuais, e alguns dos rios principais, não tendo si do delimitadas as áreas de encaixe imperfejto (recobrimento, ou falta), que constam da reconstrução orjginal dos mencio nados autores. Como a comparação somente pode ser tentada em termos das unidades maiores, a região aqui analisada en globa a da Figura 5, e foi escolhida de modo a incluir par te da área de dobramentos caririanos, a norte, e parte do Grupo Açungui, a sul. Ainda para efeito de simplificação, fo ram reunidos sob uma ünica legenda, na Figura 13, os sedimen tos do Fanerozóico das bacias cratônicas intexiores, como a do Congo, ou a do Parnajba, bem como os sedimentos meso-ceno zóicos das bacias costeiras.

Os dados geocronológicos disponíveis, do lado africa no, são escassos e heterogeneamente distribuĩdos, o que difi culta as possibilidades de correlação. Cahen e sneliing (1966) reunem os resultados disponiveis até a época, para o trecho entre o Cameroun e a Angola. Trata-se, em grande maioria, de idades Rb-Sr efetuadas em biotita, de pequeno va 
CORRELAÇÃO DAS UNIDADES GEOTECTÔNICAS DA PARTE ORIENTAL DA AMÉRICA DO SUL E DA PARTE OCIDENTAL DA ÁFRICA EQUATORIAL

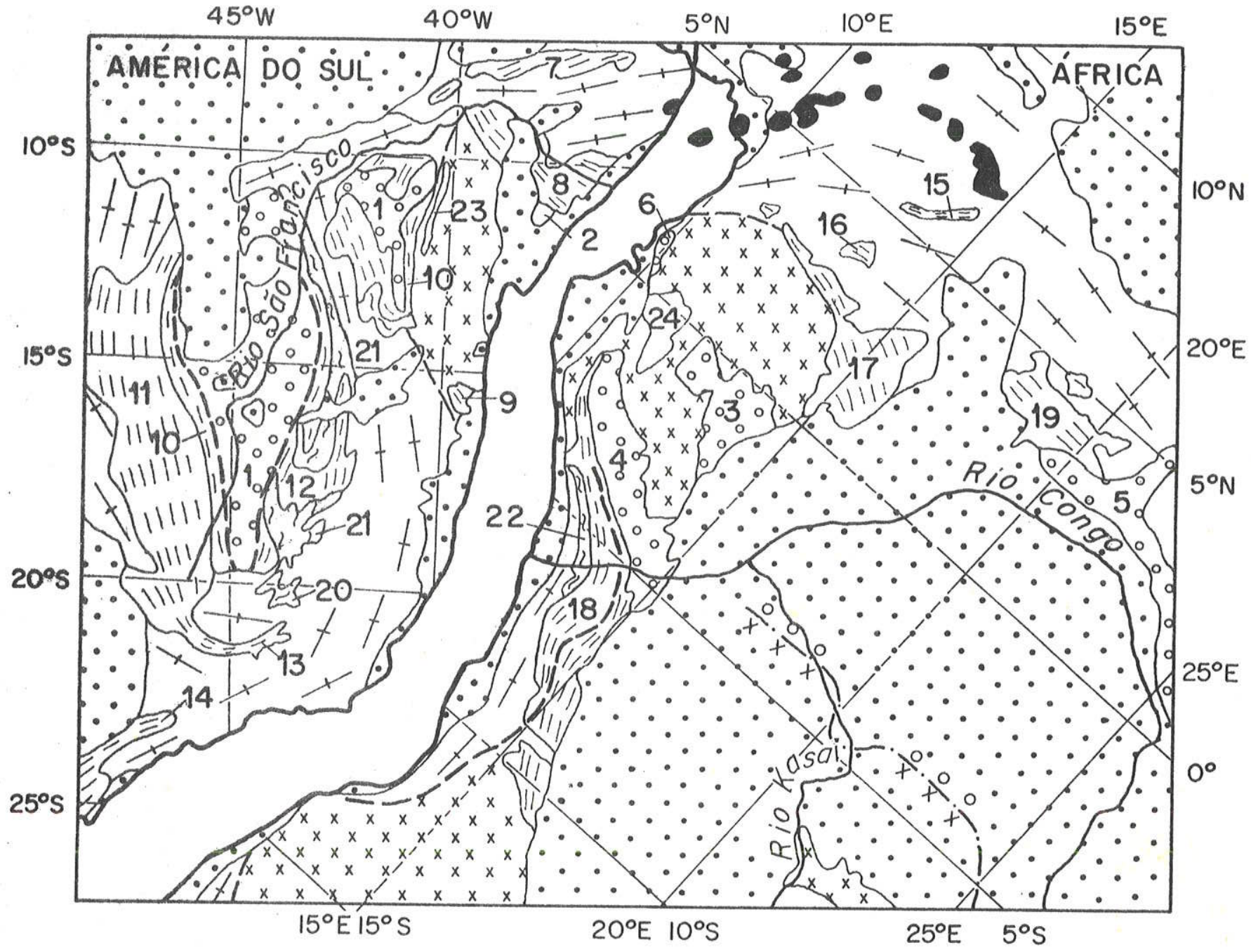

- Rochas vulcânicas recentes (Vulcões do Cameroun , Fernando Pó, Cabo Santo Agostinho)

$\because \because \because$ Coberturas sedimentares Fanerozóicas

$\because 0$ Coberturas sedimentares pré-Cambrianas, não dobradas e sem $\frac{0}{x}: \frac{0}{x}$. Limites da cobertura de plataforma pré-Cambriana, em sub-superfície

IIIIIIIII Regiões de paraplataforma, e /ou faixas de dobramentos de 450 IIIIIIIII 700 m.a.(supra-estrutura, metamorfismo até epizonal)

1,'?, ', Faixas de dobramentos anteriores, rejuvenescidas entre 450 e 700 ma. \ \. Faixas de dobramentos de 450 - 700 m.a. (infra-estrutura, e/ou zo-

$\left[\begin{array}{l}x^{x} x^{x} x^{x} x \\ x^{x}\end{array}\right]$ Plataformas estáveis no fim do pré-Cambriano

Limite da influência do ciclo orogênico de 450-700m.a. 
Fig. 13 - Correlação das unidades geotectônicas da parte oriental da Amërica do Sul e da parte ocidental da Africa Equato rial.

Nomenclatura das unidades relacionadas*

A - Coberturas sedimentares prē-Cambrianas não dobradas

1 - Grupo Bambui

2 - Formação Estância

3 - Sistema Francevilliano (1 700 m.a.)

4 - Sistema do Congo Ocidental

5 - Sistema Lindiano-Ubangiano

6 - Sêrie de Noya

B - Regiões de para-plataforma, e/ou faixas de dobramentos de $450-700 \mathrm{~m} . \mathrm{a}$.

7 - Sërie Ceará 15 - Sërie do Lom

8 - Geossinclínio Sergipano 16 - Séries Mbalmayo-Bengbis e Dja

9 - Grupo Rio Pardo 17 - Série Semba-Ouesso

10 - Grupos Lavras-Bambui 18 - Sistema do Congo Ocidental

11 - Grupo Canastra

12 - Formação Macaubas (MG)

13 - Grupo São João Del Rei

14 - Grupo Açungui

C - Faixas de dobramentos antigas, rejuvenescidas entre 450 e $700 \mathrm{~m} . \mathrm{a}$. 20 - Grupo Minas 22 - Sistema Mayumbiano

21 - Grupo Espinhaço

D - Faixas de dobramentos antigas, incluỉdas nas plataformas estáveis 23 - Grupo Jacobina 24 - Série de Ndjole

* São aqui utilizadas as denominações mais comuns para as unidades referidas, de modo que os termos "Série", "Sistema", "Grupo", "Formação", "Geossinclínio", não tềm implicações estratigrā́ícas. 
lor interpretativo. Em adição, são mencionadas algumas idâ des $\mathrm{Rb}-\mathrm{Sr}$ em feldspatos, diversas idades $\mathrm{Pb}$ modelo, e algu mas outras pelo método $\mathrm{K}-\mathrm{Ar}$. Não são mencionados estudos geocronológicos utilizando isōcronas $\mathrm{Rb}-\mathrm{Sr}$, ou dados $\mathrm{U}-\mathrm{Pb}$.

Posteriormente, alguns trabalhos importantes aparece ram, cabendo destaque, no Cameroun, aos de Lasserre (1966e 1969); no Gabon, ao de Bonhomme et al. (1965); no Zair (exRepüblica Democrática do Congo), ao de Delhal et al. (1971), e na Angola, os de Mendes (1966 e 1968) e os de Carvalho (1969, 1969a). Alguns dados adicionais, ainda não interpre tados, são encontrados em Hurley et al. (1967a e 1968), a res peito do Gabon. J.R.F. Torquato (informação verbal), dispõe de dados adicionais a respeito de Angola, provenientes de da tações K-Ar e Rb-Sr efetuadas em São Paulo.

Estes dados geocronolögicos adicionais, de qualquer forma, não alteram a interpretação da evolução geológica re gional dada por Cahen e snelling (1966), que, em grande par te, basearam-se nos dados geológicos expostos pouco antes, por Cahen e Lepersonne (1967).* Os autores mencionados, com base nos dados geológicos regionais, e nos dados geocronoló gicos disponĩveis, apresentaram o esquema da evolução geoló gica pré-cambriana da África Equatorial, que será seguido aqui, acompanhado das referências específicas sempre que um dado evento, comentado, seja referível à Figura 13.

Eis a sequência de eventos principais, de caráter orogênico, a partir dos mais antigos:

1 - Ciclo Shamvaiano

Definido na Rodésia, em rochas com cerca de 2700

* 1967 é a data da publicação da obra, embora o original re visado havia sido entregue pelos autores, em 1964 . 
m.a., aparece também no Kasai, onde constitui o complexo me tamörfico Dibaya, e o "Ciclo charnockítico". A extensão des ta área, por baixo dos sedimentos da Bacia do Congo, consti tui o embasamento do cinturão do Congo ocidental, na região $\mathrm{NE}$ de Angola. Em adição, rochas atribuídas ao Ciclo Sham vaiano aparecem junto à costa, no Gabon e na região do baixo rio Congo, onde constituem a faixa de dobramentos Zadiniana.

2 - Ciclo Limpopo (ou Eburneano, na Äfrica setentrional)

Vários cinturões foram reconhecidos como pertencen tes a este ciclo ( 1650 - 2150 m.a.), considerado como dos mais importantes na evolução africana. Trata-se das faixas de dobramentos Buganda-Toro-Kibaliana; Ubendiana-Ruzisiana, bem como da faixa Mayumbiana, de posição intermediäria entre as rochas Zadinianas e o sistema do Congo ocidental, e que é atribuỉa a este ciclo. Além disso, parece que grande parte do "Complexo de base" de Angola, foi formado ou reativado du rante o Ciclo Limpopo.

3 - Ciclo Kibariano

Este ciclo é relativamente bem definido na faixa de dobramentos do mesmo nome, na parte oriental da República do Zair (Cahen et al., 1967; Cahen et al., 1971). Os seus epi sódios ocorreram entre $] 300$ e $850 \mathrm{~m} . \mathrm{a}$., entretanto, na fai xa costeira, eventos geológicos com tal idade ainda não fo ram perfeitamente caracterizados, se não forem levadas em conta algumas determinações obtidas em rochas da parte SW de Angola, próximo de Moçamedes.

4 - Ciclo Katanga

Eventos deste ciclo são incluídos entre 450 e 750 m.a., e aparecem em extensas faixas de dobramentos que recor 
tam todo o continente Africano. A importância deste ciclo, cujas fases ocorreram entre o fim do prë-cambriano e o in cio do Paleozöico, levou Kennedy (1964) a definir um "episö dio termo-tectônico Pan-Africano", para aquela ëpoca. As ro chas sedimentares (dobradas ou não), que pertencem ao Ciclo Katanga, ocorrem no zair (Sistemas Lindiano e Ubangiano), en tre Gabon e Angola (Sistema do Congo ocidental), e em re giões menores de localização esparsa.

Os quatro ciclos geotectônicos principais, para o continente africano, são equivalentes aos existentes na Amërica do sul, de modo que è possivel correlacionar perfeita mente os Ciclos Shamvaiano e Guriense ( $2500-2900$ m.a.), os Ciclos Limpopo (Eburneano) e Trans-Amazônico ( 3.700-2 100 m.a.), os Ciclos Kibariano e Uruaçuano (Minas-Espinháço) (850 - 1400 m.a.), e os Ciclos Katanga (Pan-Africano) e Bra siliano (450 - $750 \mathrm{m.a.)}$. Entretanto, esta correlação, por si sö, não é suficiente para comprovar a união antiga entre a Åfrica e América do Sul, porque os intervalos de tempo men cionados parecem corresponder, na histöria da Terra, a épo cas de intensa atividade geodinâmica, de carāter universal,e não restrito aos continentes africano e sul-americano. Em vista disso, ë necessärio verificar se as respectivas provin cias de idade, alêm de possuir a mesma evolução geolögica, de monstrada por padrão geocronolögico similar, tem também posi ção adjacente, na reconstrução. Cabe aqui assinalar que o trabalho de Hurley et al. (1967) correlacionou com a parte congênere africana todo o trecho costeiro setentrional, atë cerca de $12^{\circ}$ de latitude.

Como os dados geocronológicos são muito escassos pa ra uma comparação completa, foi aqui escolhida a situação prë-cambriana melhor conhecida, dos pontos de vista geotectô nico e geocronolögico, para verificar as possiveis correla ções. Trata-se do intervalo entre 450 e 700 m.a., ëpoca em que na Africa desenvolviam-se os acontecimentos relativos ao 
Ciclo Katanga, e, na América do Sul, os do Ciclo Brasiliano.

No final do prē-Cambriano, a região incluída na Figu ra 13, do lado africano, mostrava uma extensa plataforma es tável, na região hoje ocupada por grande parte da República do Zair, e da Província de Angola. Tal unidade estendia-se para NW até a parte meridional do Cameroun, Guinë Espanhola e Gabon. O complexo granulítico do Ntem (Lasserre, 1964) que ocupa a parte sul do Cameroun, possui idade mínima de $2540 \mathrm{~m} . \mathrm{a}$. Algumas medidas $\mathrm{Rb}-\mathrm{Sr}$ em muscovita, realizadas por Vachette (1964) indicam idades de resfriamento da ordem de $1950 \mathrm{~m}$. a. para a região central do Gabon. Outras análi ses, efetuadas por Hurley et al. (1967a), tambëm no Gabon,mos tram valores $\mathrm{Rb}-\mathrm{Sr}$ em rocha total entre 2000 e 2600 m.a., com exceção de três valores próximos a $650 \mathrm{~m} \cdot \mathrm{a}$. (idades con vencionais empregando-se $\left(\mathrm{Sr}^{87} / \mathrm{Sr}^{86}\right)_{i}=0,705$ e $\lambda_{\mathrm{Rb}}=1,47$ x 10-" $\operatorname{anos}^{-1}$ ). Infelizmente, naquela publicação, os resul tados não são interpretados, e as localidades não são mencio nadas. Trata-se de rochas coletadas por Allard e Hurst, pos sivelmente de rochas pertencentes à sērie de Ndjole.

Sobre tal região estável, depositavam-se os sedimen tos que hoje encontram-se sob cobertura mais jovem, na bacia do Congo. Na Figura 13 aparece o limite da área de ocorrên cia destes sedimentos, por baixo da cobertura fanerozóica. Nas partes marginais da unidade estável, os sedimentos tabu lares do Ciclo Katanga constituem os sistemas Lindiano-Ubangiano (a norte), e do Congo Ocidental (a oeste).Aparecem ain da, como coberturas de plataforma, os Sistemas Francevillia no (tabular), Mbalbayo-Bengbis (dobrado), Semba-Ouesso (do brado), e Liki-Bembiano (dobrado). O primeiro deles possui idade de cerca de $1700 \mathrm{~m} . \mathrm{a}$. (Bonhomme et al., 1965), e pare ce situar-se sobre a plataforma, enquanto que os outros são de idade incerta. Na Figura 13 foram incluidos, tentativamente, no Ciclo Katanga. 
Os dobramentos e o metamorfismo que afetaram o Siste ma do Congo ocidental parecem ter sido mais intensos para oeste, aparecendo rochas rejuvenescidas em ambiente mesozo nal, na região de Boma (Cahen et al., 1963). Nesta mesma re gião aparece o granito hiper-alcalino de Noqui, que exibe um importante fenômeno de rejuvenescimento com idade de $540 \mathrm{~m}$.a. (Delhal et al., 1971). Alëm disso, rochas afetadas pelo Ci clo Katanga são assinaladas tambëm ao longo da costa de Ango la, atẻ pelo menos a localidade de Benguela. Mais para o sul, material formado ou afetado no fim do prē-Cambriano, rea parece próximo da costa. Trata-se do granito de Morro Verme Iho, pertencente ao "Damara belt", e datado por Torquato e A Zlsopp (1972) em $540 \mathrm{~m} . \mathrm{a}$., pelo mëtodo $\mathrm{Rb}-\mathrm{Sr}\left(\lambda_{\mathrm{Rb}}=147 \mathrm{x}\right.$ $\left.10^{-11} \operatorname{anos}^{-1}\right)$.

o limite norte da região estävel, jả no Cameroun, en contra as rochas epizonais pertencentes aos sistemas Semba-Ouesso, Dja e Mbalmayo-Bengbis, dobradas e metamorfizadas, muito provavelmente, durante o Ciclo Katanga. Estas rochas são adjacentes a um conjunto de xistos e gnaisses, que tomam vărias denominações, e que exibem idades aparentes $\mathrm{K}-\mathrm{Ar}$ e $\mathrm{Rb}-\mathrm{Sr}$ no intervalo 450 - $650 \mathrm{~m} \cdot \mathrm{a}$. (Lasserre, 1966 e 1969).

As direções estruturais deste conjunto mesozonal, formado e/ou rejuvenescido no Ciclo Katanga, variam entre NBSW e E-W.

A situação geológica e geogräfica descrita acima per mite agora uma comparação direta entre os dois continentes, ao longo de grande parte de suas margens Atlânticas, em con ti̊nuação às regiões já comparadas por Hurley et al. (1967). De cima para baixo na Figura 13, temos a ārea orogênica Cari riana, do lado brasileiro, adjacente à região do Cameroun,de mesma evolução geocronolögica, conforme apontavam Hurley et al. (1967). O limite sul destas províncias geocronolögicas ocorre por volta de $2^{\circ}$ de latitude Norte do lado africano,e. por volta de $11^{\circ} 30^{\prime}$ de latitude sul do lado brasileiro (posi 
ção da Formação Estância), limites relativamente bem ajusta dos na reconstrução. Sobre a plataforma estāvel, idades su periores a $1700 \mathrm{~m}$.a. são encontradas em ambos os lados, na parte sul do Estado da Bahia, e no Gabon.

Allard e Hurst (1969) compararam o Geossinclinio Ser gipano com as rochas metamörficas que constituem a sērie de Najole, no Gabon. Entretanto, a unidade geotectônica do la do brasileiro, que pertence ao Ciclo Brasiliano, constitui o limite norte do Craton de Salvador, enquanto que as rochas africanas situam-se sobre a plataforma estável, no fim do pré-Cambriano, parecendo ser de idade mais antiga (Limpopo-Eburneana). Na opinião do autor, as unidades equivalentes ao geossinclinio sergipano devem ser procuradas no Cameroun, onde possivelmente são representadas pelas sēries de Mbalbayo-Bengbis, Dja, e Semba-Ouesso, jä mencionadas, situadas no Iimite com o Complexo do Ntem.

A delimitação com a zona de influência do Ciclo Ka tanga, no sul do Gabon ou no Congo Brazzaville, não é muito precisa. Na carta tectônica da Africa(Choubert e Faure-Muret, 1968) fol colocada, sem evidênclas geocronológicas, na lati tude $4^{\circ} \mathrm{s}$. Datações da ordem de $500 \mathrm{~m} . \mathrm{a}$. em äreas próximas à costa, Indicando eventos do Ciclo Katanga, começam a ser re gistradas, com certeza, a partir de $5^{\circ}$ latitude sul. A nature za das rochas do cinturão do Congo ocldental, nesta região,tam bëm pouco ajuda, visto que os sedimentos são dobrados, mas pou co metamörficos. o grau de metamorfismo aumenta de leste pa ra oeste,e também de norte para sul, de modo que a parte se tentrional da unidade, no Gabon, pode ter sofrido tectonismo, sem que tenha havido sensivel aquecimento. Alzard $e$ Hurst (1969), estudando o maciço de Ikoundou, extremo setentrio nal da unidade, descrevem as rochas como sendo sub-horizon tais, e praticamente sem metamorfismo e deformação. Neste particular, para uma melhor fixação do limite afetado pelo ciclo Katanga, fazem-se necessārias determinações geocronoló 
gicas no trecho costeiro de Gabon, entre 2 e $4^{\circ}$ sul.

As dataçöes existentes no baixo curso do rio Congo, na Repüblica do zair, e na Angola, permitem delimitar a zona de influência do ciclo Katanga, da região de plataforma, que apresenta idades aparentes mais antigas. Tal limite $\bar{e}$ indi cado na Figura 13. Nota-se a correspondência completa com a região, pröxima da costa, afetada pelos eventos Brasilianos na América do sul. O fato do limite ser mais ou menos para lelo à costa tira as chances de encontrar, na Amërica do Sul, uma província geocronológica mais antiga que o ciclo Brasi liano na região adjacente à parte sul de Angola.

A reconstrução efetuada pexmjte visualisar, para a época entre 450 e $700 \mathrm{~m} . \mathrm{a}$., a existência de uma grande faixa de dobramentos, de direção aproximadamente paralela à atual linha da costa. Tal unidade possuia embasamento siälico,com idade de pelo menos $2000 \mathrm{~m} . \mathrm{a}$. Possivelmente, o sistema do Congo Ocidental, na Angola, e o Grupo Macaubas, no Estado de Minas Gerais, representam duas unidades simëtricas contempo râneas, a primeira adjacente à plataforma da Angola-Kasai, e a segunda adjacente à plataforma do são Francisco. Sedimen tos não dobrados aparecem sobre as duas plataformas, sendo que no lado brasileiro são representados pelo Grupo Bambuj de Minas Gerais.

As inümeras eviaências geocronológicas de que a in fra-estrutura dos cinturōes do final do prë-cambriano, em am bos os continentes, incluia rochas de $2000 \mathrm{~m} . \mathrm{a} .$, rejuvenescidas, indicam que tais unidades apresentavam embasamento de natureza siälica. Este fato, aliado à existência de nücleos estäveis muito antigos, leva a admitix que, logo apös o ci clo Trans-Amazônico (Eburneano), jä estava formada uma gran de massa continental, com crosta siálica, de tamanho equiva lente ao estimado para o "Super-Continente de Gondwana".

Em resumo, a comparação geocronológica efetuada nes te trabalho pode ser considerada positiva. Não só a evolu․ 
ção global dos dois continentes è semelhante, mas também a po sição das provincias geocronolögicas não desmente as correlações. Tal evidência constitui-se em fato altamente favorâa vel ao modelo geodinâmico de evolução terrestre que inclui a deriva dos continentes, no Fanerozóico. Quando um modelo re siste a testes cada vez mais pormenorizados, sem que suas idéias básicas sofram modificações, a convergência das evidên cias tende a torná-10 cada vez mais aceitável. Na atualidade, já são poucos os militantes das ciências geológicas que conti nuam céticos em relação à possibilidade de deriva dos conti nentes. Mais do que isso, muitos deles, entre os quais o pre sente autor, acreditam que tal fenômeno, que envolve a ocorrên cia de grandes movimentos tangenciais à superficie da Terra, possa ser considerado um "fato geolögico" comprovado, e seja assim utilizado, em conjunto com outros, para construir mode los e teorias de escala ainda maior, na tentativa de explicar adequadamente os processos geodinâmicos, suas causas e seus mecanismos. presentemente, estes são os grandes desafios das geociências. 
B I BLI OGRAFIA

ALLARD,G.O.e FUJIMORI,S. - 1966 - Ocorrência de safirina em Salvador, Bahia. Soc.Bras.Geol. 15 (2): 67-81.

ALLARD,G.O. e HURST,V.J. - 1969 - Brazil - Gabon geologic link supports continental drift. Science, 163: 528-532. ALMEIDA,F.F.M.de - 1967 - Origem e evolução da plataforma Brasileira. Div.Geol.Miner. D.N.P.M., Min.Minas e Energia, Bol. 241, Rio de Janeiro.

ALMEIDA,F.F.M.de - 1969 - Structure and dynamics of the Bra zilian coastal area. Pan-Amer.Symp. Upper Mantle, II, group II, 29-38. México. ALMEIDA,F.F.M.de, MELCHER, G.C., CORDANI,U.G., KAWASHITA, K. e VANDOROS,P. - 1968 - Radiometric age determinations from Northern Brazil. Soc.Bras.Geol. Bol.17 (1): 3-14. ALMEIDA,F.F.M.de, AMARAL,G., CORDANI,U.G. e KAWASHITA, K. - (no prezo) - The precambrian evolution of the South America cratonic margin, south of the Amazon river - in "The ocean basins and margins". Ed. A.E.M.Nairn. AMARAL,G., CORDANI,U.G., KAWASHITA,K. e REYNOLDS, J.H. 1966 - Potassium-argon dates of basaltic rocks from Southern Brazil. Geoch.et Cosmoch. Acta, 30, 159-189. AZEVEDO,H.C.A.de - 1969 - Rochas carbonatadas do sul da Bahia. CEPLAC - Com. Técnica no 28. AZEVEDO,H.C.A.de e SOUTO,P.G. - 1971 - Recursos minerais do sul da Bahia (Primeiros resultados) - CEPLAC - Bol. Técnico no 10. BARBOSA,A.L.M. de - 1966- Sintese da evolução geotectônica da América do Sul. Inst.Geol.ouro preto - 1 (2):91-111. BARBOSA,A.L.M.de, GROSSI SAD,J.H., TORRES, N. e MELLO, M.T.V.de - 1966 - Description of the preliminary geologic map of the middle Rio Doce - American Geol.Inst. Int.Field Inst. to Brazil - Guide book. 
BARBOSA DE DEUS,P. - 1972 - Geologia da Quadrícula de Camacã noroeste. CEPLAC - Bol. Técnico no 18.

BONHOMME, M., WEBER,F. e FAVRE-MERCURET,R. - 1965 - Age par le méthode rubidium-strontium des sẻdiments du Bassin de Franceville (République Gabonaise). Bull.Serv. Carte Géol. Als.Lor. 18 (4): 243-252.

BRAJNIKOV, B. - 1955 - Materiaux pour servir a la carte géologique de I'État d'Espirito Santo. Div. Geogr. E.Santo. Rel.An. para 1952, vol.l.

BULLARD,E., EVERETT,J.E. e SMITH,A.G. - 1965 - The fit of the continents around the Atlantic. In "A symposium on continental drift" - Phil.Trans.Roy.Soc.London, 258 (1088): 41-51.

CAHEN,L., DELHAL,J., LEDENT,D. e REINHARZ,M - 1963 -

L'âge des migmatites de Boma et de l'orogenèse OuestCongolienne. Indications préliminaires sur l'âge des formations Mayumbiennes et antērieures. Ann.Soc.Géol. Belg., 86 (4) : 229-269.

CAHEN,L.e SNELLING,N.J. - 1966 - The geochronology of Equatorial Africa. North-Holland Publ. Co.- Amsterdam. CAHEN,L. DELHAL,J. e DEUTSCH,S. - 1967 - Rubidium-strontium geochronology of some granitic rocks from the Kibaran belt (Central Katanga, Rep.of the Congo).Ann. Mus. Roy.Af.Centr. 8\% Sc. Gēol., no 59. CAHEN,L. e LEPERSONNE,J. - 1967 - The Precambrian of the Congo, Rwanda, and Burundi - In "The geologic systems", 3: 143-290 - Ed. K. Rankama. CAHEN, L., DELHAL,J. e DEUTSCH,S. - 1971 - Nouvelles données sur l'âge et la pëtrogenèse des granites posttectoniques de la chaîne kibarienne, Rep.dëmocratique du Congo. Ann.Soc.Géol.Belg. 94: 179-183.

CARVALHO,H. de - 1969 - Contribution à la géochronologie du sud-ouest de l'Angola - Bol. Serv.Geol. e Minas. Prov. Angola, (19).

CARVALHO,H.de - 1969a - Cronologia das Formações geológicas precâmbricas da região central do sudoeste de Ango la e tentativa de correlação com as do sudoeste Africa no. Bol.Serv.Geol. e Minas. Prov. Angola (20). 
CASTRO,C.e SIAL,A.N. - 1971 - Contribuição ao estudo das ro chas granuliticas de Salvador,Bahia - Inst.Geoc.da Univ. F. de Pernambuco - Est. e Pesq., I (2):1-19. CHOUBERT, G. e FAURE-MURET,A. - 1968 - Notices explicatives, Carte Tectonique Internationale de l'Afrique 1/5.000.000. UNESCO - Sciences de la Terre - Paris.

CORDANI,U.G. e BITTENCOURT,I. - 1967 - Estudo geocronolögico no Grupo Açungui - An. do XXI Congr.Bras.Geol.,218-233. CORDANI,U.G., MELCHER,G.C. e ALMEIDA, F.F.M.de - 1968 - Outline of the Precambrian geochronology of South America. Can.J.E.Sci., 5: 629-632.

CORDANI,U.G., ISOTTA,C.A.L. e ABREU,A.C.S. - 1969 - Reconhe cimento geocronológico do embasamento na região oriental do Estado da Bahia - An.XXIII Congr.Bras.Geol. - 159-165. CORDANI,U.G. e KAWASHITA,K. - 1971 - Estudo geocronológico, pelo método $\mathrm{Rb}-\mathrm{Sr}$, de rochas graníticas intrusivas no Grupo Açungui - An. do XXV Congr.Bras.Geol., 105-110. CORDANI,U.G., DELHAL, J. e LEDENT, D. - 1973 - Orogenèses superposées dans le Precambrien du Brésil sud-oriental (États de Rio de Janeiro et de Minas Gerais) - Rev.Bras. de Geoc., 3 (1):1-22.

DELHAL,J., LEDENT, D. e CORDANI,U.G. - 1969 - Ages $\mathrm{Pb} / \mathrm{U}$,

$\mathrm{Sr} / \mathrm{Rb}$ et $\mathrm{Ar} / \mathrm{K}$ des formations métamorphiques et granitiques du sud-Est du Brésil (États de Rio de Janeiro et de Minas Gerais). Annal.Soc.Gēol.Belgique, 92, 271-283. DELHAL, J., LEDENT, D., PASTEELS,P. e VENIER,J. - 1971 -

Etude du comportement isotopique de systèmes $\mathrm{Rb} / \mathrm{Sr}$ et $\mathrm{U} / \mathrm{Pb}$ dans le granite hyperalcalin de Noqui (Rep.démocratique du Congo et Angola). Ann.Soc.Géol.de Belgique, 94: 223-236. DEUTSCH,S., LEDENT,D. e PASTEELS,P. - 1965 - Datation par les methodes $\mathrm{Sr} / \mathrm{Rb}$ et $\mathrm{Pb} / \mathrm{U}$ au Laboratoire de Géochrono logie du Service de Geologie et Geochimie Nucleaires. Univ.Libre de Bruxelles. EBERT,H. - 1962 - Baustil und regionalmetamorphose im kristallinen Praekambrium Brasiliens. Tschermaks Min. Petr.Mitt, Wien III, Ser.8, 49-81. 
EBERT,H. - 1968 - Ocorrências de fäcies granulítica no sul de Minas Gerais e en äreas adjacentes, em dependência de estrutura orogênica: hipōteses sobre sua origem -An.Acad. Bras.Ciênc., 40 (supl.) : 215-229.

FERREIRA,E.O. - 1972 - Carta rectônica do Brasil. Notícia explicativa. Min.Minas Energia. D.N.P.M., Bol. 1. FUJIMORI,S. - 1967 - Rochas alcalinas do sul do Estado da Bahia. Div.Geol.Mineral.D.N.P.M. - Notas Prel.e Est.nol41. FUJIMORI,S. - 1968 - Granulitos e charnockitos de Salvador,

Bahia - An.Acad.Bras.Ciênc., 40 (2): 181-202. GAMOT,E., PHILIBERT,J.e VIALETTE,Y. - 1970 - Dosage par absorption atomique du potassium, du rubidium et du strontium em vue de mesures geochronologiques. Trav. du Dept. de Geol. et Minér.de la Fac.Sci.de Clermont,n: 7. GUIMAR AEES,D. - 1924 - Contribuição à petrographia do Brasil.

Serv. Geol. Miner., Bol. 6 . GUIMARÃES,D. - 1951 - Arqui-Brasil e sua evolução geológica. Div.Fom.Prod.Min., Bol. 88. GUIMARAES,D. e SOUZA,H.C.A. - 1931 - Estudo petrogräphico das rochas colhidas nos arredores da cidade da Bahia. An. Acad. Bras. Sci., 3 (4): 177-185. HERZ,N. - 1970 - Gneissic and igneous rocks of the Quadrilätero Ferrífero,Minas Gerais, Brazil. U.S.G.Survey, Prof. Paper 641-B. HILDRETH,R.A. e HENDERSON,W.T. - 1971 - Comparison of $\mathrm{Sr}^{87} / \mathrm{Sr}^{86}$ for sea water strontium and the Eimer and Amend $\mathrm{SrCO}_{3}$. Geoch. Cosmoch. Acta 35 (2): 235-238. HURLEY,P.M., ALMEIDA,F.F.M.de, MELCHER, G.C., CORDANI,U.G., RAND,J.R., KAWASHITA,K., VANDOROS,P., PINSON JR.,W.H. e FAIRBAIRN,H.W. - 1967 - Test of continental drift by comparison of radiometric ages. Science,157, 495-500. HURLEY,P.M., FAIRBAIRN,H.W., PINSON JR.,W.H.e colaboradores

- $1967 a$ - M.I.T. Annual Progress Report for 1967. HURLEY,P.M., FAIRBAIRN,H.W., PINSON JR.,W.H., NAYLOR,R.S. e colaboradores - 1968 - M.I.T. Annual Progress Report for 1968 . 
KAWASHITA, K. - 1972 - O mëtodo $\mathrm{Rb}-\mathrm{Sr}$ em rochas sedimentares. Aplicação para as Bacias do Paranã e do Amazonas. Tese de Doutoramento. Inst.Geoc. da USP.

KENNEDY,W.Q. - 1964 - The structural differentiation of Afri ca in the Pan-African $( \pm 500 \mathrm{~m} . \mathrm{y}$.$) tectonic episode. Res.$ Inst.Afr. Geol. Univ.Leeds $-8^{\text {th }}$ Ann.Rep.Sci. Results: 48-49.

LASSERRE,M.- 1964 - Etude géochronologique par la methode Rubidium-strontium de quelques échantillons en provenance du Cameroun (Afrique Equatoriale). Ann.Fac.Sci.Clermont, (25), Geol, et Min. 8: 53-67. LASSERRE,M. - 1966 - Nouvelles mesures d'âges absolus, par la méthode au strontium-rubidium, concernant les formations cristallines et cristallophylliennes du CamerounRapport BRGM, Yaoundë et orléans. LASSERRE,M. - 1969 - Cameroun: examen des résultats gēochronologiques obtenus depuis 1967. Ann.Fac.Sci. Clex mont, (41), Geol.et Min.19: 29-31. LEDENT, $D$. e PASTEELS,P. - 1968 - Détermination de 1 'age des roches post-tectoniques du sud-est du Brésil. Ann.Soc.Gëol. Belgique, 91 (III): 305-309. $M A A C K, R$. - 1963 - Geologia e geografia física da bacia hidrográfica do Rio de Contas no Estado da Bahia. Inst. Geol. da Univ.do Paraná. Bol.Geogr.Fís. no 5. MENDES,F. - 1966 - Ages absolus par la méthode au strontium de quelques roches d'Angola. Compte Rendus Acad. Sci.paris, 262 : 2201-2203. MENDES,F. - 1968 - Mesures gēochronologiques en Angola. $2^{\text {ème }}$ These Doct.ès Sci. Nat. Fac.Sci.clemont-Ferrand. MORAES REGO,L.E.de - 1947 - As estruturas antigas do Brasil. Bol.Geogr., 5 (50) : 126-129. PEDREIRA,A.J, SOUTO,P.G. e AZEVEDO,H.C.A.Cle - 1969 - Metas sedimentos do Grupo Rio Pardo, Bahia, Erasil. An.XXIII Congr. Bras.Geol. , 87-99. REINHARZ,M., DELWICHE, $R$, e KATZ,J. - 1962 - Snectrometre de masse du laboratoire de Geologie et Geochimie Nucleaires. Univ.Libre de Bruxelles. 
REYNOLDS,J.H. e SPIRA,R. - 1966 - Individual tracers for isotope diluition analysis of rare gases - Nuclear Inst. and Meth, , 42, 225-228.

SHIELDS,R.M. - 1963 - A computer program to calculate a least squares isochron and associated errors. M.I.T. Annual Report for 1963: 149-152.

SIGHINOLFI,G.P. - 1970 - Investigations into the deep levels of the continental crust: petrology and chemistry of the granulite facies terrains of Southern Bahia (Brazil). Atti Soc.Tosc.Sc.Nat. Mem.A77, 327-341.

SIGHINOLFI,G.P. e FUJIMORI,S. - 1972 - Granadas nos granulitos de Salvador, Bahia: Discussão sobre relações entre sua variação química e reações metamōrficas - Rev.Bras.Geoc. , 2 (3) : 141-150. SOUTO,P.G., BEZERRA,J.C., SAMPAIO,E. e VILAS BOAS,G. - 1971 Geologia da Folha de Mascote noroeste - CEPLAC - Bol. Técni co n8 12.

SOUTO,P.G., AZEVEDO,H.C.A.de e BEZERRA,J.C. - $1971 \alpha$ - Geologia da Folha de Potiraguá nordeste - CEPLAC - Bol. Técnico no 15.

SOUTO,P.G., AZEVEDO,H.C.A.de e PEDREIRA,A.J. - 1972 - Geologia da Folha de Camacan sudoeste - CEPLAC - Bol. Técnico n8. 20 .

SUSZCZYNSKI, E.F. - 1967 - La tectonique et la gẻologie de la partes orientale du bouclier brésilien. Soc.Géol.Fran ce Ser. 7 (9): 147-152.

TAVORA,F.J., CORDANI,U.G. e KAWASHITA,K. - 1967 - Determina ções geocronológicas na região central da Bahia pelo método Potāssio-argônio. An.do XXI Congr.Bras.Geol.-234-244. TORQUATO,J.R.F. e ALLSOPP,H.L. - 1972 - Rubidium-strontium geochronology of granitic rocks from the Morro Vermelho Area (Tiger-Bay, Angola) - Geol. Rund.,63.

VACHETTE,M. - 1964 - Mesures d'âges absolus des formations cristallines d'Afrique Equatoriale (Gabon, Rẻp.Centrafricaine, Tchad, Moyen Congo).Ann.Fac.Sci.Clermont: 31-38. VOSTERS,M. e DEUTSCH,S. - 1967 - Atomic absorption spectro-. photometry of rubidium in rocks and minerals.Comparison with isotope dilution.Earth and Plan.Sci.Letters, 2 (5): $449-452$. 
APENNDICE I

Descrição sucinta das amostras analisadas

São aqui descritas, de modo resumido, quase todas as rochas analisadas no presente trabalho. Somente três de las, (Ped-4, SA-43D e 525), cujos dados analiticos foram extraídos de trabalho que não incluia descrição das amostras, não puderan ser caracterizadas. Procurou-se dar ênfase à composição mineralógica, e as fases presentes em cada amostra foram relacionadas na ordem correspondente à porpor ção em que ocorrem.

A título de simplificação, foi empregado o seguinte código para os minerais relacionados:

$\begin{array}{lll}\text { Ab - Albita } & \text { Flo - Flogopita } & \text { Op - Opaco(s) } \\ \text { Ant- Antipertita } & \text { Flu - Fluorita } & \text { Or - Ortocläsio } \\ \text { Ap - Apatita } & \text { Gr - Granada } & \text { Pert-Pertita } \\ \text { Au - Augita } & \text { Hb - Hornblenda } & \text { Pi - Pigeonita } \\ \text { Bi - Biotita } & \text { Hip - Hiperstênio } & \text { Pl - Plagioclásio } \\ \text { Cal- Calcita } & \text { KF - K-feldspato } & \text { Qz - Quartzo } \\ \text { Can- Cancrinita } & \text { Mes - Mesopertita } & \text { Se - Sericita } \\ \text { Car- Carbonato } & \text { Mi - Microclínio } & \text { Si - Sillimanita } \\ \text { Cl - Clorita } & \text { Mq - Mirmequita } & \text { So - Sodalita } \\ \text { Co - Cordierita } & \text { Mu - Muscovita } & \text { Ta - Talco } \\ \text { Di - Diopsidio } & \text { NaA - Na-anfibólio } & \text { Ti - Titanita } \\ \text { Eg - Egirina } & \text { Ne - Nefelina } & \text { Tr - Tremolita } \\ \text { Ep - Epidoto } & \text { Ol - Olivina } & \text { Zc - Zircão }\end{array}$

Texturas e outros caracteres julgados importantes são descritos a seguir. Para a granulação, empregou-se terminologia simplificada (grossa, mẻdia, fina), com delimitações entre as três categorias situadas, aproximadamente, em 
1 e $5 \mathrm{~mm}$.

Para a denominação das rochas, foi adotada uma nomenclatura o mais possível simplificada, mas suficiente para caracterizar as variedades petrogräficas principais.

No caso das rochas metamörficas de facies granulito, segue-se nesse trabalho o esquema utilizado por Fujimori (1968), que empregou o têrmo que caracteriza a facies, seguido do atributo "ácido" ou "bảsico", conforme a paragênese individual, de cada amostra. Tal classificação evita o emprego de termos mais específicos, como "leptinito", "enderbito", "charnockito", etc., nem sempre adequados para descrever rochas heterogêneas, bandadas, com variações petrogräficas relativamente grandes em distâncias pequenas. $\bar{A}$ denominação "granulito âcido", neste trabalho, correspondem rochas félsicas, quartzo-feldspäticas, formadas em facies granulito. Por outro lado, "granulito básico" corresponde a rochas de mesmo grau de metamorfismo, que evidenciam quan tidade substancial de minerais escuros, associados a plagio clâsio intermediārio a cálcico.

Para as rochas metamörficas que ocorrem na faixa costeira, entre Porto Seguro e Vitőria, cuja paragênese essencial ë quartzo-plagioclāsio intermediärio-granada-biotita, e que apresentam, frequentemente ortoclásio, cordierita e sillimanita, foi empregado o termo "gnaisse kinzigítico". Estas rochas mereceram denominação especial, para déstacálas da categoria seguinte, constituida por gnaisses normais, formados em facies anfibolito. Os "gnaisses kinzigiticos" não puderam, nesse trabalho, serem definitivamente caracterizados como rochas pertencentes ao facies granulito, ou à subfacies mais alta do facies anfibolito.

No caso das rochas metamórficas feldspäticas de facies anfibolito, empregou-se a denominação "gnaisse", prece dida do(s) mineral(is) acidental(is) mais comum(ns) (biotita, muscovita, hornblenda). Os termos "anfibolito", "xis- 
to", "filito", "ardōsia", "mārmore", das demais rochas metamörficas, bem como os termos "sienito", "granito", "diabā sio", e"piroxenito", das rochas magmáticas encontradas, foram utilizados de acordo com seus significados normais.

Rochas de transição, ou rochas híbridas, foram denominadas da seguinte maneira: manteve-se a denominação "granu lito" para aquelas que, embora evidenciando minerais formados em fases metamōrficas posteriores, de grau mais baixo, exibissem uma paragêse primäria, de facies granulito, predominante. Analogamente, manteve-se a denominação "gnaisse" ou "anfibolito", para aquelas rochas que apresentaram, como ves tígios, pequenas quantidades de minerais tais como piroxênios, ou mesopertitas, evidências de paragêneses primärias de grau mais elevado. Em ambos os casos mencionados, é óbvio que a associação mineralógica relacionada, para cada amostra, evidencia desequilíbrio termodinâmico.

Eis a relação das principais caracteristicas petrogrảficas das rochas estudadas, aqui listadas em ordem alfabé tica:

ALM-1 - Gnaisse kinzigítico

Ponte sobre o rio Jequitinhonha, Almenara, (MG)

Col. Umberto Cordani

PI (+Ant) $-\mathrm{KF}-\mathrm{Qz}-\mathrm{Bi}-\mathrm{Gr}$.

Textura granoblástica e porfiroblástica, granulação mẻdia a grossa. Coloração branca,orientação mal definida.

ALM-104 B e C - Tremolita-xisto

$20 \mathrm{~km}$ E de Joaima, estrada para Felizburgo, (MG)

Col. Umberto Cordani

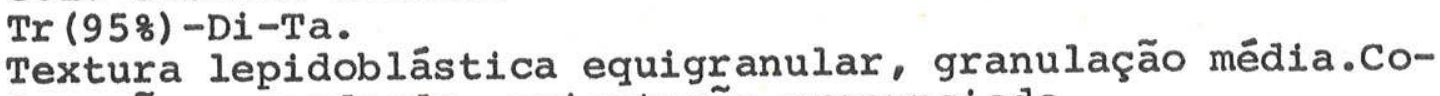
loração esverdeada, orientação pronunciada.

ALM-186 - Biotita-gnaisse

$4 \mathrm{~km}$ NW de Palmópolis, estrada para Rio do Prado, (MG)

Col.Umberto Cordani

$\mathrm{P} 1-\mathrm{Qz}-\mathrm{Bi}-\mathrm{KF}$

Bandas alternadas de textura granoblástica e lepidoblästị ca, granulação média. 
$A P-X$ - Hornblenda-gnaisse

Sede da CEPLAC, cerca de $5 \mathrm{~km}$ ENE de Itabuna, estrada pa ra Ilhẻus. Col. A.Pedreira

$\mathrm{P} 1-\mathrm{Hb}-\mathrm{Qz}-\mathrm{Ep}-\mathrm{Op}-\mathrm{Cl}-\mathrm{Bi}$

Coloração esverdeada, textura granoblāstica, granulação

média. Sinais de cataclase.

$\mathrm{BA}-69-8$ - Filito

$19 \mathrm{~km}$ S de Camacã, rodovia BR-101, pröximo da ponte sobre o rio Pardo. Col. Umberto Cordani

Se-Qz-C1-Op-Mat.detríticos diversos

Coloração clara, xistosidade pronunciada. Textura lepidoblăstica, granulação fina.

BA-69-13A - Ardôsia

Estrada Camacã-Canavieiras, proximidades de Jacarandá(BA)

Col. Umber to Cordani

Se-Qz-Mat.detriticos diversos-Op-Car

Clivagem ardosiana, coloração cinza claro. Textura lepiido blästica, granulação fina.

$\mathrm{BA}-69-17 \mathrm{~A}, \mathrm{~B}, \mathrm{C}, \mathrm{F}, \mathrm{G}$ - Sienito

Fazenda Hiassu, cerca de $25 \mathrm{~km} \mathrm{~S}$ de Itajú do Colônia, (BA). Col.Umberto Cordani

A,B e C - Rochas com coloração azulada, granulação mẻdia a grossa, textura hipidiomörfica granular. $\mathrm{KF}-\mathrm{SO}-\mathrm{Ab}-\mathrm{Bi}-\mathrm{Op}$

F e G - Veios de sodalita pura, granulação grossa.Coloração branca e/ou acinzentada.

BJ-10 - Granulito ácido

Cerca de $10 \mathrm{~km}$ NE de Brejões, estrada para Amargosa, (BA). Col. Umberto Cordani

Pert-Mes-Or-Qz-Mq-Bi-Op

Aspecto maciço, orientação pouco pronunciada. Granulação média a grossa, textura granoblástica e porfiroblástica, anhedral.

CÃ-18 - Filito

Cerca de $18 \mathrm{~km} \mathrm{~S}$ de Camacã, rodovia BR-101, (BA). Col.Umm berto Cordani

$\mathrm{Se}-\mathrm{Cl}-\mathrm{Qz}-\mathrm{Mat}$.detríticos diversos-Op

Coloração clara, xistosidade pronunciada, brilho intenso. Textura lepidoblästica, granulação fina.

CÃ-39 - Filito

Cerca de $39 \mathrm{~km} \mathrm{~S}$ de Camacã, rodovia BR-101, (BA). Col.Um berto Cordani

Se-Cl-Qz-Op-Mat.detríticos diversos.

Coloração clara,xistosidade e lineação pronunciadas, com microdobras.Textura lepidoblästica,granulação fina. 
CÃ-75 A,B - Mucovita-biotita gnaisse

Rodovia $\mathrm{BR}-101,4 \mathrm{~km} \mathrm{~N}$ da ponte sobre o rio Jequitinhonha (BA). Col. Umberto Cordani

$\mathrm{Mi}-\mathrm{Qz}-\mathrm{P} \mathrm{I}-\mathrm{Mu}-\mathrm{Bi}-\mathrm{Flu}$

Rocha bandada, com enclaves micáceos. Textura granoblásti ca, em parte lepidoblástica, granulação média.

CÃ-78 A,B,C,D - Biotita-muscovita-gnaisse

Rodovia $\mathrm{BR}-101,1 \mathrm{~km} \mathrm{~N}$ da ponte sobre o rio Jequitinhonha (BA) . Col.Umberto Cordani

Rocha bandada, alternância de camadas granulares e xistosas. Bandas milimétricas a centimétricas, orientação nítí da. Sinais de cataclase intensa.

A - Textura granoblästica, em parte lepidoblāstica, granulação fina a média $\mathrm{Mi}-\mathrm{Qz}-\mathrm{P} I-\mathrm{Bi}-\mathrm{Ep}-\mathrm{Mu}-\mathrm{Ti}$

C - Rocha similar, sem microclínio, com mais quantidade de muscovita

B - Banda xistosa clara, com Qz-Mu-KF-Flu

D - Textura lepidoblāstica, poiquiloblástica, granulação média

$\mathrm{Bi}-\mathrm{Qz}-\mathrm{Hb}-\mathrm{Gr}-\mathrm{Op}-\mathrm{Mi}-\mathrm{Ep}-\mathrm{T} \mathrm{i}-\mathrm{P} \mathrm{l}-\mathrm{Ap}$

CÃ-81 - Biotita gnaisse

Rodovia BR-101, $1 \mathrm{~km} \mathrm{~S}$ da ponte sobre o rio Jequitinhonha (BA) . Col. Umberto Cordani

$\mathrm{KF}-\mathrm{Bi}-\mathrm{Hb}-\mathrm{Pl}-\mathrm{Qz}-\mathrm{Ep}-\mathrm{Op}-\mathrm{Ap}$

Rocha bandada, textura granoblástica, em parte lepidoblás tica, granulação média.

CASC-A,B - Gnaisse kinzigitico

Rodovia Medeiros Neto-Alcobaça, ponte sobre o rio Itanhëm (BA). Col. Umberto Cordani

Gr-Bi-Qz-P1-Co-Si-Pert-Hip-Ep

Rocha heterogênea, porfiroblästica. Textura granoblástica e poiquiloblâstica, granulação média a grossa.

$\mathrm{CB}-\mathrm{CAI}$ - Märmore

Fazenda Santa Terezinha, cerca de $10 \mathrm{~km} \mathrm{~S}$ de Gurupä Mirim (BA) . Col. P.G.Souto

Cal-Qz-Flo-Op

Orientação nittida de finas bandas xistosas. Textura grano blästica equigranular, granulação fina.

CB-43-34 - Anfibolito

Cerca de $4 \mathrm{~km}$ WSW de Caiubi (BA) . Col. P.G.Souto

$\mathrm{Hb}-\mathrm{P} 1-\mathrm{Ca}$ l-Qz-Ep-Bi-Op-Ap

Lineação bem desenvolvida, aspecto maciço. Textura nemato blästica, granulação média. 
CO-53 - Gnaisse kinzigítico

Cerca de $12 \mathrm{~km}$ NNW de Santa Tereza, estrada para Colatina (ES). Col. Umberto Cordani

$\mathrm{P} 1-\mathrm{Q} z-\mathrm{Bi}-\mathrm{Gr}-\mathrm{Ap}-\mathrm{Hip}$

Coloração esverdeada, aspecto maciço homogêneo. Textura granoblástica anhedral, granulação mẻdia.

Co-66 - Gnaisse kinzigitico

Cerca de $2 \mathrm{~km} \mathrm{NE}$ de Santa Tereza, estrada para Vitöria(ES) . Col. Umberto Cordani

Pert-Qz-Bi-Co-Gr-Si

Bandeamento centimëtrico. Textura granoblästica, granulação média.

CO-120 - Biotita gnaisse

$30 \mathrm{~km} \mathrm{SE}$ de Fundão, estrada para Vitória(ES) . Col.umberto Cordani

Pl-Qz-Bi-Pert-Mu-Cl-Op-Car

Rocha bandada, coloração cinza claro. Textura granoblásti ca, em parte lepidoblăstica, granulação média.

EU-4I B,C - Gnaisse kinzigítico

$19 \mathrm{~km} \mathrm{E}$ de Guaratinga, estrada para Itamaraju(BA)

Col. Umberto Cordani

$\mathrm{Bi}-\mathrm{Qz}-\mathrm{Gr}-\mathrm{P} \mathrm{I}-\mathrm{Co}-\mathrm{Or}-\mathrm{Si}$

Rocha bandada, porfiroblästica. Textura granoblástica e poiquiloblástica, granulação média a grossa

Veios feldspáticos cortando as rochas.

EU-61 - Biotita gnaisse

$1 \mathrm{~km} W$ de Guaratinga, estrada para Buranhém (BA)

Col. Umberto Cordani

$\mathrm{P} I-\mathrm{Qz}-\mathrm{KF}-\mathrm{Bi}-\mathrm{Op}-\mathrm{Ap}$

Homogênea, com orientação nítida. Textura lepidoblāstica, em parte granoblästica, granulação média.

F-48 - Granulito ăcido

$20 \mathrm{~km} \mathrm{~N}$ de Camacã, rodovia BR-101 (BA).Col.S. Fujimori

$\mathrm{KF}-\mathrm{Mes}-\mathrm{Qz}-\mathrm{Bi}-\mathrm{Hip}$

Homogênea, orientação nítida, coloração rosada. Textura granoblästica anhedral, granulação mẻdia.

FB-3 - Piroxenito

Farol da Barra, Salvador, BA. Col. S. Fujimori

Di (90\%) -P1-Cl-Se-Bi

Dique intrusivo em rochas granuliticas

Textura granular xenomórfica, granulação média.

GD-67 - Granulito ácido

Rodovia BR-101, entroncamento com a estrada para Valença (BA). Col. Umberto Cordani

$\mathrm{Mi}-\mathrm{Q} z-\mathrm{P} 1-\mathrm{Mes}-\mathrm{Hb}-\mathrm{Ep}-\mathrm{Cl} \mathrm{I}-\mathrm{Ti}$

Coloração rósea, aspecto maciço. Indícios de cațaclase. Textura granoblástica anhedral, granulação média. 
GH $-8-7$ - Traquito

Vizinhanças da Faz.Santa Terezinha, cerca de $13 \mathrm{~km}$ SSE de Gurupá Mírim (BA). Col. P.G.Souto

$\mathrm{KF}-\mathrm{Ab}-\mathrm{NaA}-\mathrm{Bi}-\mathrm{Ne}-\mathrm{Op}$

Dique intrusivo em granulitos, aspecto homogêneo, afaníti co. Textura traquítica, granulação fina.

GOV-68 - Pegmatito

$2 \mathrm{~km}$ SW de Divino das Laranjeiras, estrada para Gov. Vala dares (MG). Col. Umberto Cordani

$\mathrm{KF}-\mathrm{Qz}-\mathrm{Mu}$

Textura pegmatitica.

Dique intrusivo em rochas graniticas.

GOV-98 - Gnaisse kinzigítico

Cerca de $20 \mathrm{~km}$ NE de Divino das Laranjeiras, estrada para Mantena (ES/MG). Col. Umberto Cordani

$\mathrm{Pl}-\mathrm{Qz}-\mathrm{Bi}-\mathrm{Gr}$

Coloração clara, rocha homogênea. Textura granoblăstica, granulação média.

GOV-208 - Gnaisse kinzigítico

$20 \mathrm{~km}$ NW de São Domingos, estrada para Mantena (ES)

Col. Umberto Cordani

$\mathrm{P} 1-\mathrm{KF}-\mathrm{Qz}-\mathrm{Bi}-\mathrm{Gr}$

Homogênea, porfiroblästica, cristais maiores centimëtricos. Textura granoblástica, poiquiloblástica, granulação média a grossa.

IL-11 - Granulito bäsico

$11 \mathrm{~km}$ NW de Ilhéus, estrada para Uruçuca (BA). Col. Umber to Cordani

$\mathrm{Pl}-\mathrm{Qz}-\mathrm{Hb}-\mathrm{Hip}-\mathrm{Bi}-\mathrm{Op}-\mathrm{Ti}$

Coloração cinzenta, maciço, orientação pouco pronunciada. Textura granoblästica anhedral, granulação mẻdia.

IP-176 - Granulito ácido

Estrada Poções-Itabuna, vizinhanças de Nova Canaã (BA).

Col. Umberto Cordani

Mi-Qz-Mes-Bi-Cl-Ep-Ap-Op-Se

Coloração escura. Orientação nítida. Cataclase.Textura gra noblästica anhedral, granulação média.

IT-5 - Sienito

Sede da CEPIAC, cerca de $5 \mathrm{~km}$ ENE de Itabuna, estrada para Ithẻus (BA). Col. S.Fujimori

Or-Ne-Ab-Bi-So

Textura hipidiomörfica granular, granulação média.

ITA-37 - Biotita xisto

Estrada Itapetinga-Maiquinique, $14 \mathrm{~km} \mathrm{~S}$ da ponte sobre 0 rio Pardo (BA). Col. Umberto Cordani

$\mathrm{Bi}-\mathrm{Qz}-\mathrm{P} 1-\mathrm{Op}-\mathrm{Ep}$

Rocha homogênea, xistosa.Textura lepidoblästica, granulação média. 
ITA-104 - Anfibolito

Estrada Salto da Divisa-Jordânia, $23 \mathrm{~km}$ NW da ponte sobre o rio Jequitinhonha (MG). Col. Umberto Cordani

$\mathrm{Hb}-\mathrm{P} 1-\mathrm{Au}-\mathrm{KF}-\mathrm{OP}$

Maciço, orientação pronunciada, coloração escura. Textura granoblástica, granulação média.

ITA-122 - Biotita gnaisse

Estrada Salto da Divisa-Jordânia, $5 \mathrm{~km}$ NW da ponte sobre o rio Jequitinhonha (MG). Col. Umberto Cordani

$\mathrm{Mi}-\mathrm{P} \mathrm{L}-\mathrm{QZ}-\mathrm{Bi}-\mathrm{Hb}-\mathrm{ZC}$

Homogeneo, coloração rosada, orientação nítida. Textura granoblástica, em parte lepidoblástica, granulação média.

ITA-126 - Biotita gnaisse

Estrada Salto da Divisa-Jordânia, $1 \mathrm{~km} \mathrm{~W}$ da ponte sobre 0 rio Jequitinhonha (MG). Col. Umberto Cordani

$\mathrm{Qz}-\mathrm{P} 1-\mathrm{Mi}-\mathrm{Bi}-\mathrm{Hb}-\mathrm{Ep}-\mathrm{T} \mathrm{i}-\mathrm{Mu}-\mathrm{Cl}$

Homogêneo, coloração rosada, orientação nítida. Textura granoblästica, em parte lepidoblästica,granulação média.

ITAR-2,3 - Sienito

Cerca de $20 \mathrm{~km}$ SSW de Itarantim(BA).Col. J.Mascarenhas

$\mathrm{KF}-\mathrm{Ne}-\mathrm{PI}-\mathrm{Bi}-\mathrm{Ti}$

Textura hipidiomórfica granular, granulação grossa.

ITB-88 - Anfibolito

Rodovia Itabuna-Vitöria da Conquista, proximidades de Fir mino Alves (BA). Col. Umberto Cordani

$\mathrm{Hb}-\mathrm{P} 1-\mathrm{Qz}-\mathrm{Au}-\mathrm{OP}$

Banda escura em rochas gnäissicas, orientação nitida.Textura granoblástica anhedral, granulação média.

ITB-219 - Biotita gnaisse

Rodovia Itabuna-Vitória da Conquista, subida da Serra Geral, SE de Vitöria da Conquista. Col. Umberto Cordani

$\mathrm{Mi}-\mathrm{Qz}-\mathrm{Bi}-\mathrm{Hb}-\mathrm{P} \mathrm{I}-\mathrm{Ep}-\mathrm{Op}-\mathrm{Ap}-\mathrm{ZC}$

Rocha heterogênea, orientada, com enclaves xistosos. Textura granoblästica, em parte lepidoblästica, granulação média.

ITC-29 - Sienito

Cerca de $32 \mathrm{~km}$ SE de Vitöria da Conquista, rodovia para Itabuna (BA). Col. Umberto Cordani

$\mathrm{KF}-\mathrm{Eg}-\mathrm{Bi}-\mathrm{NaA}$

Textura porfiritica, com fenocristais de feldspato milimé tricos matriz fina. Dique em rochas granuliticas.

ITJ-46 - Granulito bäsico

$2 \mathrm{~km} \mathrm{w}$ de Almadina, estrada para Ibitupã (BA) . Col. Umber to Cordani

P 1-Hip-Hb-Au-Bi-Op

Coloração escura, homogêneo, maciço. Textura granoblästica anhedral, granulação médía. 
ITJ-62A - Granulito bäsico

$2 \mathrm{~km} \mathrm{~N}$ de Floresta Azul, estrada para Almadina (BA). Col. Umberto Cordani

$\mathrm{P} 1-\mathrm{Hb}-\mathrm{H} i \mathrm{p}-\mathrm{Au}-\mathrm{Qz}-\mathrm{Bi}-\mathrm{Ep}-\mathrm{Op}$

Homogêneo, maciço. Bandas escuras em granulitos ācidos. Textura granoblấstica anhedral, granulação média.

JE-13 A,C,D - Granulito ácido

$13 \mathrm{~km}$ de Jequié, estrada para Ipiau(BA). Col.Umberto Cordani

Rocha bandada, colorações rosadas a negras, aspecto maci ço. Evidênclas de cataclase. Textura granoblästica anhe= dral, granulação média.
A - Tipo escuro com feldspato róseo: KF (+Pert)-Qz-P1-Mes $-\mathrm{Bi}-\mathrm{Hb}-\mathrm{Mq}-\mathrm{Ap}-\mathrm{Op}-\mathrm{Ep}$
C - Tipo rosado: Mes-Qz-Bi-Hb-Ap
$D$ - Tipo escuro: Mes-Or-Hb-Au-Qz-Mq-Bi-Op-Ap.

JE-23 - Granulito básico $23 \mathrm{~km}$ ESE de Jequié, estrada para Ipiau (BA) . Col. Um$\mathrm{Hb}-\mathrm{Au}-\mathrm{P} \mathbf{1}-\mathrm{Qz}-\mathrm{Bi}-\mathrm{Ep}-\mathrm{Ap}-\mathrm{Op}$

Color ação escura, mactço. Textura granoblästica poiquilo blästica anhedral, granulação mëdia.

JE-50 - Granulito bäsico

50 km ESE de Jequié, estrada para Ipiau (BA) . Col. Umberto Cordani

$\mathrm{P} 1-\mathrm{Hb}-\mathrm{Hi} \mathrm{p}-\mathrm{Au}-\mathrm{Qz}-\mathrm{Bi}$

Coloração escura, maciço, orientação nitida. Textura lepidoblástica, sub-anhedral, granulação média.

JE-70 - Granulito bäsico

$8 \mathrm{~km}$ WNW de Ipiau, estrada para Jequié (BA) . Col. Umberto Cordani

P1-Hip-Au-Qz-Bi

Coloração escura, maciço. Textura granoblāstica poiquilo blāstica, anhedral, granulação média.

M-Pa - Gnaisse kinzigitico

Encosta NW do Monte Pascoal (BA). Col.umberto Cordani

Bi-Pert-Mes-Co-Qz-P 1-S1-Op-Mu

Rocha homogênea, xistosa, porfiroblästica. Textura grano

blástica e porfiroblästica, granulação média a grossa.

MU-19 C,D,E - Granulito ācido

$1 \mathrm{~km} \mathrm{E}$ de Ubaira, estrada para Mutuipe (BA). Col. Umberto Cordani

Rocha bandada, coloração cinza claro a escuro. Variedades róseas. Sinais de cataclase. Textura granoblástica anhedral, granulação média.

C - Tipo leucocrätico: Mes-Qz-Bi-Op-Ep 


$$
\begin{aligned}
& \text { D - Tipo cinzento: Mes-Qz-P1-Hip-Bi-Op-Ap-Ep } \\
& \text { E - Tipo escuro: Qz-Mes-P1-Bi-Hip-Op-Ap-Cl. }
\end{aligned}
$$

MU-60 - Granulito äcido

$2 \mathrm{~km} \mathrm{~S}$ de Brejões, estrada para Santa Inès (BA). Col. Umberto Cordani

Mes-Qz-Hb-P1-Bi-Op-Ap-Hip

Bandado, color ação esverdeada, orientação pouco desenvol vida. Textura granoblästica anhedral, granulação média= grossa.

NQ-O - Gnaisse kinzigitico

Nanuque (MG). Col. Umberto Cordani

$\mathrm{KF}-\mathrm{P} \mathbf{1}-\mathrm{B} i-\mathrm{Gr}-\Omega \mathbf{z}$

orientação nitida. Textura porfiroblästica, com feldspatos centimëtricos, matriz de granulação mëdia.

NQ-103A - Biotita gnaisse

Epaminondas otoni (MG) . Col. Umberto Cordani

$\mathrm{P} 1-\mathrm{KF}-\mathrm{Bi}-\mathrm{Qz}$

Bandado, coloração cinzenta. Textura granoblästica, em parte lepidoblästica, granulação média.

NV-1B - Gnaisse kinzigitico

$1 \mathrm{~km} W$ de Nova Venécia, estrada para são Domingos (ES). Col. Umberto Cordani

Mes-Qz-P 1-Bi-Co

Rocha leucocrática, maciça. Textura granoblāstica, granu lação grossa.

NV-126 - Gnaisse kinzigítico

Colatina (ES). Col. Umberto Cordani

$\mathrm{KF}-\mathrm{Qz}-\mathrm{B} i-\mathrm{Gr}-\mathrm{Mes}-\mathrm{CO}-\mathrm{Si}$

Homogênea, orientação nítida. Textura granoblästica e poi quiloblástica, granulação média.

ONDINA-2,2a - Di.abäsio

Praia de Ondina, Salvador (BA). Col. Petrobräs S.A. $\mathrm{Pi}(+\mathrm{Au})-\mathrm{P} 1-\mathrm{Bi}-\mathrm{OP}-\mathrm{H} \mathrm{H}-\mathrm{Ap}-\mathrm{Cl}$

Dique intrusivo em granulitos. Textura sub-ofitica, granulação fina, sendo mais fina na amostra $2 a$.

PB-33-27 - Filito

Cerca de $18 \mathrm{~km} \mathrm{~S}$ de Camacã, pouco a $W$ da rodovia $B R-101$

(BA) . Col. P.G.Souto

Se-Cl-Qz-Mat.detríticos diversos-Op

Coloração cinza clara, xistosidade pronunciada. Textura lepidoblástica, granulação fina.

Ped-4 - Granulito (?)

Dado compilado do MIT Annual Report (1968).

Não hä referências sobre o tipo de rocha analisado. Localização aproximada: $\mathrm{N}$ de Salvador(BA) . Col.G.Allard (?) 
PINHEIRO - Gnaisse kinzigítico

Localidade de Pinheiro, cerca de $50 \mathrm{~km}$ NNE de Nova Venécia (ES). Col. Umberto Cordani

$\mathrm{Gr}-\mathrm{Ant}(+\mathrm{P} 1)-\mathrm{Qz}-\mathrm{KF}-\mathrm{Bi}$

Homogêneo, orientação visível. Textura granoblástica e porfiroblấstica, granulação média a grossa.

POTIG-1,3 - Sienito

Cerca de $10 \mathrm{~km}$ NE de Potiraguä (BA). Col. S.Fujimori

$\mathrm{KF}-\mathrm{Ne}-\mathrm{Bi}-\mathrm{NaA}-\mathrm{So}-\mathrm{Can}$

Textura hipidiomórfica granular, granulação média.

PRA-165 A,B - Gnaisse kinzigítico

$5 \mathrm{~km} \mathrm{SE}$ de Ibirapuã, estrada para Nanuque (BA).

Col. Umberto Cordani

Bandada, com faixas leucocrāticas e escuras alternadas.

Textura granoblästica, granulação grossa.

A - Tipo leucocrático: Mi-Qz-Mes-Bi-Gr

B - Tipo esverdeado:, $2 z-M i-M e s-G r-B i-M u-C l$

R.VERM-1 - Granulito básico

Praia do Rio Vermelho, Salvador (BA). Col.Petrobrás S.A. Pl-Hip-Bi-Hb-Au

Homogêneo, maciço, coloração escura. Textura granoblástica, granulação média.

R.VERM-la - Diabásio

Praia do Rio Vermelho, Salvador (BA). Col.Petrobrás S.A. Pl-Au-Op-Ol-produtos de alteração

Textura porfirítica, intergranular, granulação fina. Dique intrusivo em granulitos.

S-70A - Sienito

Cerca de $20 \mathrm{~km}$ NNE de Potiraguã(BA).Col.S.Fujimori

$\mathrm{KF}-\mathrm{Ab}-\mathrm{Ne}-\mathrm{NaA}-\mathrm{Bi}-\mathrm{Can}$

Textura hipidiomórfica, granular, granulação mẻdia.

S-88A - Sienito

Cerca de $20 \mathrm{~km}$ NNE de Potiraguá(BA) - Col.S.Fujimori

$\mathrm{KF}-\mathrm{Ne}-\mathrm{NaA}-\mathrm{Ab}-\mathrm{Bi}-\mathrm{Can}$

Textura hipidiomórfica granular, granulação média.

SA-43D - Granulito (?)

Dado compilado do MIT Annual Report, (1968).

Não há referências sobre o tipo de rocha analisado. Localização aproximada: NE de Salvador (BA) . Col.G.Allard (?) .

SALV-A,B - Diabásio

Pedreira Fabriciano,Salvador (BA) . Col. A.J.Melfi

$\mathrm{Pl}-\mathrm{Au}-\mathrm{Hb}-\mathrm{Bi}-\mathrm{Op}-\mathrm{Qz}$-produtos de alteração

Textura sub-ofítica, granulação fina. Dique intrusivo em granulitos. 
SALV-5 - Granulito bảsico

Farol da Barra, Salvador (BA) . Col. C.Durrell

$\mathrm{Pl}-\mathrm{Qz}-\mathrm{Hip}-\mathrm{Op}-\mathrm{Bi}$

Maciço, escuro, orientação pouço pronunciada. Textura gra noblăstica, anhedral, granulação fina a média.

SAJ-26 - Granulito ácido

$18 \mathrm{~km}$ E de Amargosa, estrada para Santo Antonio de Jesus

(BA). Col. Umberto Cordani

Mi-Mes-Qz-P 1-Hb-Cl-Op-Ep-ZC

Coloração rósea, orientąção incipiente. Textura granoblás tica anhedral, granulação média.

SD-4IA - Gnaisse kinzigítico

$10 \mathrm{~km} \mathrm{E}$ de Jacinto, estrada para Salto da Divisa (MG).

Col. Umberto Cordani

Mes-Bi-Gr-Co-Qz-P 1-Op-Si

Homogênea, porfiroblästica e poiquiloblástica, granulação média a grossa.

$\mathrm{SE}-46 \mathrm{~A}$ - Granulito ảcido

Rodovia $\mathrm{BR}-116,5 \mathrm{~km}$ SW da ponte sobre o rio Paraguaçu

(BA). Col. Umberto Cordani

Mes-Qz-Mi-Pl-Hb-Ap

Coloração rōsea, orientação incipiente. Textura granoblās tica anhedral, granulação mẻdia.

VI-28 - Gnaisse kinzigítico

Rodóvia Vitöria-Manhuaçu, km 28 (ES).Col.umberto Cordani $\mathrm{Qz}-\mathrm{P} \mathrm{l}-\mathrm{Bi}-\mathrm{Gr}-\mathrm{KF}$

Homogêneo, orientação visível.Textura granoblástica euhedral, granulação média.

VI-62A - Biotita-hornblenda gnaisse

Rodovia Vitória-Manhuaçu, km 62 (ES). Col.Umberto Cordani $\mathrm{Qz}-\mathrm{P} 1-\mathrm{Hb}-\mathrm{Bi}-\mathrm{Ti}-\mathrm{Ap}$

Bandeamento nitido, partes claras quartzo-feldspăticas e partes escuras xistosas. Textura granoblástica, em parte nematoblāstica, granulação média.

VI-103 - Biotita gnaisse

Rodovia Vitória-Manhuaçu, km 103 (ES).Col.umberto Cordani $\mathrm{Mi}-\mathrm{Qz}-\mathrm{P} 1-\mathrm{Bi}-\mathrm{Hb}$

Homogêneo, orientação nítida. Textura granoblästiça, em parte lepidoblästica e poiquiloblästica, granulação média.

VI-176A - Granulito bảsico

Rodovia Vitöria-Manhuaçu, $8 \mathrm{~km}$ E de Pequiá (ES). Col. Umberto Cordani

P I-Hip-Au-Bi-Ap-Op

Bandado, aspecto migmatîtico, coloração escura. Textura granoblắstica, granulação média. 
VQ-412B - Granulito básico

Rodovia BR-116, $5 \mathrm{~km}$ SW de Feira de Santana (BA).

Col. Umberto Cordani

$\mathrm{Pl}-\mathrm{Hb}-\mathrm{Hip}-\mathrm{Ti}-\mathrm{Ep}-\mathrm{Au}$

Bandado, coloração alternadamente clara e escura. Sinais de cataclase. Textura granoblástica, anhedral, granulação média.

$10 a B-66$ - Granulito bāsico

Rodovia Salvador-Feira de Santana, $20 \mathrm{~km} \mathrm{NE}$ de Salvador

(BA). Col. G.C.Melcher

$\mathrm{Pl}-\mathrm{Hip}-\mathrm{Qz}-\mathrm{Bi}-\mathrm{Op}-\mathrm{Hb}$

Homogêneo, coloração escura, orientação incipiente. Textú ra granoblästica anhedral, granulação fina.

76 - Granito

Vitória, ponte principal (ES) . Col. Umberto Cordani

Mi-Pl-Qz-Bi-Mq-Se-Car

Sem orientação, coloração rósea. Textura hipidiomórfica granular, granulação mé̉iia.

$78 a$ - Gnaisse kinzigítico

Vitória, ponte principal (ES) . Col. Umberto Cordani

$\mathrm{Bi}-\mathrm{Qz}-\mathrm{P} 1$ (+Ant) $-\mathrm{Gr}-\mathrm{KF}-\mathrm{Ap}-\mathrm{Op}-\mathrm{ZC}$

Homogênea, orientação visível. Textura granoblästica,granulação média.

525 - Granulito (?)

Dado compilado do MIT Annual Report, (1968)

Não há referências sobre o tipo de rocha analisado.

Localização aproximada: Cachoeira(BA).Col.G.Allard (?) • 


\section{APENDICE 2 - DETERMINAÇÕES Rb-Sr - DADOS ANALITICOS}

\begin{tabular}{|c|c|c|c|c|c|c|c|c|c|c|c|c|}
\hline No Campo & Rocha* & D. I. & $\begin{array}{l}\text { b. ppm } \\
\text { A. A. }\end{array}$ & F. X. & D.I. & $\begin{array}{l}\text { ppm } \\
\text { F. X. }\end{array}$ & $\mathrm{Sr}^{87} / \mathrm{Sr}^{86}$ & $\mathrm{Rb}^{87} / \mathrm{Sr}^{86}$ & $\begin{array}{l}\mathrm{Rb} \text { tot } / \mathrm{s} \\
\text { D.I. }\end{array}$ & $\begin{array}{l}\text { tot } \\
F \cdot X .\end{array}$ & $\begin{array}{l}\text { Idade** } \\
\text { conv. }\end{array}$ & $\operatorname{Ref} * * *$ \\
\hline$B A-69-8$ & Filito & 145,5 & 146,1 & & $41,1^{+}$ & & 0,792 & 10,20 & 3,54 & & 580 & 5 \\
\hline$B A-69-13 A$ & Ardosia & 90,7 & 92,9 & & 39,8 & & 0,770 & 6,57 & 2,28 & & 670 & 4 \\
\hline$B A-69-17 A$ & Sienito & 261 & 265 & & 10,47 & & 1,436 & 72,7 & 24,9 & & 680 & 5 \\
\hline$B A-69-17 B$ & Sienito & 348 & 354 & & 18,50 & & 1,256 & 54,1 & 18,8 & & 690 & 5 \\
\hline$B A-69-17 C$ & Sienito & 337 & 383 & & 15,29 & & 1,311 & 63,3 & 22,0 & & 650 & 5 \\
\hline$B A-69-17 F$ & Sodalita (veio) & $15,56^{\nabla}$ & & & 28,7 & & 0,727 & 1,560 & 0,542 & & 580 & 5 \\
\hline$B J-10$ & Granulito ácido & 309 & 329 & 324 & 29,0 & 32,3 & 1,903 & 30,7 & 10,7 & 10,0 & 2600 & 4 \\
\hline CÃ-18 & Filito & 110,5 & 111,4 & & 41,0 & & 0,774 & 7,77 & 2,70 & & 600 & 4 \\
\hline Cथ̃-39 & Filito & 168,4 & 143,0 & & 54,6 & & 0,789 & 8,90 & 3,08 & & 640 & 4 \\
\hline$C \widetilde{A}-75 \AA$ & Musc.biot.gnaisse & 384 & 391 & & 32,2 & & 1,413 & 34,3 & 11,9 & & 1390 & 4 \\
\hline$C \tilde{A}-75 B$ & Musc.biot. gnaisse & 403 & 354 & 341 & 30,6 & 19,5 & 1,386 & 37,8 & 13,2 & 17,5 & 1210 & 4 \\
\hline$\tilde{C A}-78 \AA$ & Biot.musc.gnaisse & 95,6 & 101,7 & & 920 & & 0,723 & 0,301 & 0,104 & & 3950 & 5 \\
\hline $\mathrm{CA}-78 \mathrm{~B}$ & Muscovita xisto & 214 & 227 & & $211^{+}$ & & 0,751 & 2,93 & 1,014 & & 1060 & 5 \\
\hline $\mathrm{C} \tilde{\mathrm{A}}-78 \mathrm{C}$ & Biot.musc.gnaisse & 119,7 & 112,6 & & 451 & & 0,722 & 0,767 & 0,265 & & 1491 & 4 \\
\hline$C \widetilde{A}-78 D$ & Gnaisse kinzigítico & 136,1 & 174,6 & 151,7 & 337 & 373 & 0,722 & 1,170 & 0,404 & 0,407 & 980 & 5 \\
\hline CASC-A & Gnaisse kinzigítico & 212 & 201 & & 36,8 & & 0,849 & 16,56 & 5,76 & & 590 & 4 \\
\hline CASC-B & Gnaisse kinzigitico & 137 & 137,2 & 141,7 & 144,1 & 147,6 & 0,746 & 2,75 & 0,951 & 0,960 & 1010 & 4 \\
\hline$E U-41 B$ & Gnaisse kinzigitico & 88,3 & 97,3 & & 30,6 & & 0,789 & 8,31 & 2,89 & & 680 & 4 \\
\hline EU-4IC & Gnaisse kinzigitico & & & 92,6 & & 83,0 & 0,757 & 3,15 & & 1,116 & 1110 & 61 \\
\hline
\end{tabular}


APENDICE 2 - continuação

\begin{tabular}{|c|c|c|c|c|c|c|c|c|c|c|c|c|}
\hline N: Campo & Rocha* & D. I. & A. $\mathrm{A}$. & F. X. & D.I. & Fpom. & $\mathrm{Sr}^{87} / \mathrm{Sr}^{86}$ & $\mathrm{Rb}^{87} / \mathrm{Sr}^{86}$ & $\begin{array}{l}\mathrm{Rb}{ }^{\text {tot }} \\
\mathrm{D} \cdot \mathrm{I} \text {. }\end{array}$ & $\begin{array}{l}r^{\text {tot }} \\
\text { F.X. }\end{array}$ & $\begin{array}{l}\text { Idade** } \\
\text { conv. }\end{array}$ & $\operatorname{Ref} * * *$ \\
\hline GD-67 & Granulito ácido & & & 190,5 & & 39,4 & 1,207 & 13,67 & & 4,84 & 2460 & 7 \\
\hline GH-8-7 & Traquito & 153,1 & 109,4 & & 69,5 & & 0,763 & 6,38 & 2,20 & & 610 & 4 \\
\hline IP-I76 & Granulito ácido & & & 231,5 & & 45,3 & 1,272 & 14,42 & & 5,11 & 2620 & 6 \\
\hline$I T A-122$ & Biotita gnaisse & 138 & 138 & & 46,1 & & 0,789 & 8,61 & 2,99 & & 660 & 4 \\
\hline ITC-29 & Sienito & $473 \phi$ & 503 & 467 & 188,3 & 187,8 & 0,776 & 7,26 & 2,51 & 2,49 & 660 & 5 \\
\hline JE-13A & Granulito ácido & & & 358,3 & & 92,7 & 1,177 & 10,92 & & 3,87 & 2880 & 6 \\
\hline$J E-13 C$ & Granulito ácido & 254 & 252 & & $20,7^{+}$ & & 2,12 & 35,1 & 12,27 & & 2660 & 5 \\
\hline$J E-13 D$ & Granulito ácido & & & 131,1 & & 79,1 & 0,893 & 4,68 & & 1,657 & 2680 & 7 \\
\hline MU-19C & Granulito ácido & & & 128,1 & & 25,2 & 1,617 & 14,39 & & 5,08 & 4200 & 7 \\
\hline MU-19D & Granulito ácido & & & 165,6 & & 175,3 & 0,838 & 2,67 & & 0,945 & 3310 & 6 \\
\hline MU-19E & Granulito ácido & & & 212,6 & & 94,4 & 0,998 & 6,35 & & 2,25 & 3070 & 7 \\
\hline $\mathrm{MU}-60$ & Granulito ácido & & & 227,5 & & 66,8 & 1,099 & 9,61 & & 3,41 & 2740 & 6 \\
\hline$N V-1 B$ & Gnaisse kinzigítico & 158,9 & 158,5 & 172,1 & 88,5 & 95,2 & 0,759 & 5,19 & 1,745 & 1,808 & 700 & 4 \\
\hline$P B-33-27$ & Filito & 168,4 & & & 56,0 & & 0,791 & 8,68 & 3,01 & & 670 & 4 \\
\hline Ped-4 & Granulito (?) & & & & & & 0,773 & 2,12 & & & 2140 & 1 \\
\hline PRA-165A & Gnaisse kinzigítico & 158,3 & 164,4 & 166,1 & 66,2 & 59,9 & 0,782 & 6,91 & 2,39 & 2,77 & 750 & 4 \\
\hline PRA-165B & Gnaisse kinzigítico & & & 128,5 & & 111,5 & 0,746 & 3,26 & & 1,152 & 850 & 7 \\
\hline$S A-43 D$ & Granulito (?) & 317,9 & & & 99,2 & & 0,975 & 9,62 & 3,20 & & 1880 & 1 \\
\hline SAJ -26 & Granulito ácido & $185,9 \phi$ & 188,7 & 189,2 & 43,5 & 44,9 & 1,162 & 12,42 & 4,27 & 4,21 & 2460 & $5 \omega$ \\
\hline
\end{tabular}


APENDICE 2 - continuação

\begin{tabular}{|c|c|c|c|c|c|c|c|c|c|c|c|c|}
\hline No Campo & Rocha* & D. I. & A. A. & F. X. & D.I. & $\stackrel{\text { ppm }}{\mathrm{F} . \mathrm{X}}$ & $\mathrm{Sr}^{87} / \mathrm{Sr}^{86}$ & $\mathrm{Rb}^{87} / \mathrm{Sr}^{86}$ & $\begin{array}{l}\mathrm{Rb} \text { tot } / \\
\text { D.I. }\end{array}$ & $\begin{array}{l}r^{\text {tot }} \\
\text { F.X. }\end{array}$ & $\begin{array}{l}\text { Idade** } \\
\text { conv. }\end{array}$ & $\operatorname{Ref} * *$ \\
\hline$S D-4 I A$ & Gnaisse kinzigítico & $188,3 \phi$ & 189,2 & 193,3 & 104,9 & 110,0 & 0,768 & 5,18 & 1,795 & 1,757 & 820 & 5 \\
\hline $\mathrm{SE}-46 \mathrm{~A}$ & Granulito ácido & & & 181,6 & & 34,0 & 1,280 & 15,10 & & 5,34 & 2540 & 7 \\
\hline 76 & Granito & 155,3 & & & 449 & & 0,718 & 1,002 & 0,346 & & 880 & 2 \\
\hline $78 a$ & Gnaisse granatifero & 164,3 & & & 128,9 & & 0,745 & 3,75 & 1,275 & & 720 & 3 \\
\hline 525 & Granulito (?) & 104,0 & & & 57,5 & & 0,847 & 5,38 & 1,809 & & 1770 & 1 \\
\hline
\end{tabular}

* Todas as determinações foram efetuadas em rocha total.

** Idade convencional, calculada empregando-se $\lambda_{\mathrm{Rb}}=1,47 \times 10^{-11} \mathrm{anos}^{-1} \mathrm{e}\left(\mathrm{Sr}^{87} / \mathrm{Sr}^{86}\right)_{i}=0,705$

*** Analista, métodos e equipamentos utilizacos, e/ou referências:

1 - P.Hurley e colaboradores, M.I.T. - (M.I.T. Ann.Rep., 1968; Cordani et al.,1968).

2 - D.Iedent e P.Pasteels, Bruxelas - (Iedent e Pasteels, 1968).

3 - U.Cordani, Bruxelas - (Cordani et al., 1973).

4 - U.Cordani, Bruxelas - Rb por D.I. e A.A. no Serv.de Geol.et Geoch. Nucleaires- ULB.

Sr por D.I. em espectrômetro Varian-Atlas CH4 do Serv.de Min.e Petrologie - ULE.

$\mathrm{Rb}$ por F.X. (M.Berenholc) no C.P.Geo - São Paulo.

5 - U.Cordani e C.Cingolani, Bruxelas. Metodologia como no item 4.

6 - U.Cordani, K.Kawashita e M.Berenholc, São Paulo - Rb e Sr por FX

Comp.isot. Sr no espectrômetro tipo Reynolds, do C.P.Geo, São Paulo.

7 - U.Cordani, K.Kawashita e M.Berenholc, São Paulo - Rb e Sr por FX

Comp.isot. Sr no espectrômetro Varian TH-5, do C.P.Geo, São Paulo.

Menores modificações para o esquema acima são indicadas, na tabela, junto aos prōprios dados analíticos.

$\nabla$ - Anal. 4 - Análise de Rb no espectrômetro Varian-Atlas CH4 do Serv.de Min. et Petrologie - ULB

$\phi$ - Anai. 5 - Análises de Ro por C.Cingolani, no espectrômetro Nuclide do INGEIS, Ia Plata, ARG.

+ - Anal. 5 - Análise de Sr no espectrốmetro do Serv.de Geol.et Geoch. Nucleaires, ULB. 


\section{APENNDICE 3 - DETERMINAÇÕES K-Ar - DADOS ANALITTICOS}

\begin{tabular}{|c|c|c|c|c|c|c|c|}
\hline NO CAMPO & $\mathrm{ROCHA}$ & MATERIAI & $18 \mathrm{IAB}(\mathrm{SPK})$ * & $\% \mathrm{~K} * *$ & $\begin{array}{c}\mathrm{Ar}^{40} \mathrm{rad} \operatorname{ccSTP} / \mathrm{g} \\
\times 10^{-5}\end{array}$ & $\therefore \mathrm{Ar}^{40} \mathrm{~atm}$ & $\begin{array}{l}\text { Idade apar., } \\
\text { m.a.*** }\end{array}$ \\
\hline ALM-1 & Gnaisse kinzigitico & Biotita & 2380 & 7,83 & 16,61 & 17,1 & $470 \pm 30$ \\
\hline$A L M-104 B$ & Tremolita xisto & Tremolita & 2307 & 0,231 & 0,577 & 32,5 & $541 \pm 33$ \\
\hline ALM- $104 \mathrm{C}$ & Tremolita xisto & Tremolita & 2312 & 0,0680 & 0,224 & 34,1 & $700 \pm 40$ \\
\hline ALM-186 & Biotita gnaisse & Biotita & 2335 & 7,68 & 18,90 & 4,8 & $490 \pm 20$ \\
\hline$A P-X$ & Anfibólio gnaisse & Anfibōlio & 1557 & 1,202 & 6,26 & 4,0 & $991 \pm 30$ \\
\hline$B A-69-17 F$ & Veio de sodalita & Sodalitabranc & 2487 & 0,525 & 1,857 & 14,4 & $727 \pm 11$ \\
\hline$B A-69-17 G$ & Veio de sodalita & Sodalita cinz & 2489 & 0,1660 & 0,394 & 68,5 & $517 \pm 46$ \\
\hline C $\tilde{A}-18$ & Filito & Rocha total & 1834 & 2,47 & 5,28 & 3,0 & $471 \pm 30$ \\
\hline$C \tilde{A}-39$ & Filito & Rocha total & 1835 & 3,04 & 6,96 & 1,67 & $501 \pm 45$ \\
\hline$C \tilde{A}-81$ & Biotita gnaisse & Anfibólio & 1962 & 1,95 & 5,01 & 12,3 & $554 \pm 32$ \\
\hline CASC-B & Gnaisse kinzigitico & Biotita & 1971 & 7,59 & 14,69 & 1,51 & $432 \pm 20$ \\
\hline $\mathrm{CB}-\mathrm{CAI}$ & Mármore & Flogopita & $\begin{array}{c}2332(1831 R) \\
1831\end{array}$ & $\begin{array}{l}8,77 \\
8,62\end{array}$ & $\begin{array}{l}21,3 \\
19,4\end{array}$ & $\begin{array}{r}47,4 \\
6,0\end{array}$ & $\begin{array}{l}527 \pm 50 \\
494 \pm 35\end{array}$ \\
\hline$C B-43-34$ & Anfibolito & Anfibōlio & 1842 & 1,256 & 2,91 & 5,3 & $506 \pm 25$ \\
\hline $\mathrm{CO}-53$ & Biotita gnaisse & Biotita & 2359 & 7,89 & 21,9 & 3,4 & $716 \pm 10$ \\
\hline $\mathrm{CO}-66$ & Gnaisse kinzigitico & Biotita & 2394 & 7,98 & 16,22 & 3,2 & $451 \pm 7$ \\
\hline $\mathrm{CO}-120$ & Biotita gnaisse & Biotita & 2356 & 7,92 & 15,94 & 2,7 & $447 \pm 6 !$ \\
\hline EU-6I & Biotita gnaisse & Biotita & 2385 & 7,63 & 15,91 & 12,4 & $460 \pm 30 \mathrm{G}$ \\
\hline
\end{tabular}




\begin{tabular}{|c|c|c|c|c|c|c|c|c|}
\hline N: CAMPO & ROCHA & MATERIAI & N: I & $\operatorname{LAB}(\mathrm{SPK}) *$ & $8 \mathrm{~K} * *$ & $\begin{array}{c}\mathrm{Ar}^{40} \mathrm{rad} \operatorname{ccSTP} / \mathrm{g} \\
\times 10^{-5}\end{array}$ & $\therefore \mathrm{Ar}^{40} \mathrm{~atm}$ & 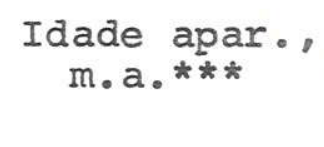 \\
\hline$F-48$ & Granulito ácido & Biotita & & 780 & 7,83 & 158,1 & 1,60 & $2459 \pm 80$ \\
\hline$F B-3$ & Piroxenito & Rocha total & & 2609 & 0,578 & 4,38 & 13,5 & $1314 \pm 26$ \\
\hline $\mathrm{GH}-8-7$ & Traquito & Rocha total & & 1836 & 4,46 & 9,21 & 2,09 & $460 \pm 10$ \\
\hline GOV -68 & Pegmatito & Muscovita & & 2231 & 8,68 & 18,93 & 11,4 & $480 \pm 8$ \\
\hline GOV-98 & Gnaisse kinzigitico & Biotita & & 2384 & 7,93 & 16,18 & 1,7 & $452 \pm 5$ \\
\hline GOV-208 & Gnaisse kinzigitico & Biotita & & 2221 & 7,54 & 16,12 & 8,8 & $472 \pm 28$ \\
\hline$I L-1 I$ & Granulito básico & Biotita & & 2283 & 7,25 & 81,7 & 7,1 & $1726 \pm 64$ \\
\hline$I T-5$ & Sienito & Biotita & & 762 & 7,70 & 19,88 & 10,1 & $556 \pm 20$ \\
\hline ITA-37 & Biotita xisto & Biotita & & 2211 & 7,86 & 15,67 & 79,4 & $443 \pm 34$ \\
\hline ITA-104 & Anfibolito & Anfibólio & & 2001 & 0,699 & 1,743 & 16,9 & $540 \pm 31$ \\
\hline ITA-126 & Biotita gnaisse & Biotita & & 2219 & 6,92 & 15,11 & 82,3 & $480 \pm 54$ \\
\hline ITAR $-2,3$ & Sienito & Biotita & & 2628 & 7,64 & 16,21 & 4,4 & $469 \pm 14$ \\
\hline ITB -88 & Anfibolito & Anfibōlio & & 1841 & 0,324 & 3,74 & 3,0 & $1769 \pm 55$ \\
\hline ITB-219 & Biotita gnaisse & Biotita & Am. & padrão ${ }^{\nabla}$ & 5,08 & $11,75^{\nabla \nabla}$ & - & $506 \pm 12$ \\
\hline$I T J-46$ & Granulito básico & Anfibölio & & 1969 & 0,244 & 3,17 & 6,7 & $1891 \pm 91$ \\
\hline ITJ $-62 \mathrm{~A}$ & Granulito básico & Anfibölio & & 1970 & 1,355 & 4,36 & 23,7 & $672 \pm 12$ \\
\hline$J E-23$ & Granulito básico & Anfibōlio & & 1953 & 1,101 & 5,77 & 8,8 & $997 \pm 16$ \\
\hline $\mathrm{JE}-50$ & Granulito básico & Anfibōlio & & 2212 & 0,266 & 7,19 & 82,2 & $2850 \pm 300 \quad 6$ \\
\hline $\mathrm{JE}-70$ & Granulito bäsico & Anfibólio & & 1964 & 0,636 & 7,55 & 24,9 & $1786 \pm 491$ \\
\hline
\end{tabular}




\begin{tabular}{|c|c|c|c|c|c|c|c|c|}
\hline NO CAMPO & ROCHA & MATERIAI & $\mathrm{LAB}(\mathrm{SPK})$ * & $8 \mathrm{~g} * *$ & $\begin{array}{c}\operatorname{Ar}^{40} \mathrm{rad} \operatorname{ccSTP} / \mathrm{g} \\
\times 10^{-5}\end{array}$ & $\approx \operatorname{Ar}^{40} a t m$ & $\begin{array}{l}\text { Idade } \\
\text { m.a. }\end{array}$ & $\underset{\star \star \star \star}{\operatorname{apar}}$ \\
\hline $\mathrm{M}-\mathrm{Pa}$ & Gnaisse kinzigítico & Biotita & 1972 & 7,80 & 16,76 & 2,5 & 474 & \pm 8 \\
\hline NQ $-O$ & Gnaisse kinzigítico & Biotita & 2215 & 7,76 & 18,95 & 82,8 & 539 & \pm 66 \\
\hline $\mathrm{NQ}-103 \mathrm{~A}$ & Biotita gnaisse & Biotita & 2214 & 7,79 & 16,94 & 81,5 & 477 & \pm 74 \\
\hline NV-126 & Gnaisse kinzigítico & Biotita & 2395 & 7,71 & 15,60 & 4,0 & 450 & \pm 7 \\
\hline ONDINA-2 & Diabāsio & Rocha total & 2612 & 0,575 & 6,50 & 31,1 & 1731 & \pm 34 \\
\hline ONDINA-2a & Diabāsio & $\begin{array}{l}\text { Rocha total } \\
\text { Plagioclásio }\end{array}$ & $\begin{array}{l}2627 \\
2467\end{array}$ & $\begin{array}{l}0,465 \\
0,473\end{array}$ & $\begin{array}{l}4,04 \\
4,69\end{array}$ & $\begin{array}{l}9,4 \\
4,0\end{array}$ & $\begin{array}{l}1449 \\
1587\end{array}$ & $\begin{array}{l} \pm 20 \\
\pm 18\end{array}$ \\
\hline PINHEIRO & Gnaisse kinzigitico & Biotita & 2222 & 7,95 & 18,52 & 3,8 & 509 & \pm 12 \\
\hline POTIG-1 & Sienito & Biotita & 1562 & 6,94 & 13,16 & 10,4 & 424 & \pm 35 \\
\hline POTIG-3 & Sienito & Anfiböiio & 1049 & 1,908 & 7,27 & 1,75 & 765 & \pm 40 \\
\hline R.VERM-I & Granulito bāsico & $\begin{array}{l}\text { Plagioclásio } \\
\text { Biotita }\end{array}$ & $\begin{array}{l}2586 \\
2600\end{array}$ & $\begin{array}{l}0,236 \\
7,26\end{array}$ & $\begin{array}{l}2,63 \\
69,0\end{array}$ & $\begin{array}{r}21,8 \\
5,3\end{array}$ & $\begin{array}{l}1714 \\
1541\end{array}$ & $\begin{array}{l} \pm 16 \\
\pm 15\end{array}$ \\
\hline R.VERM-Ia & Diabāsio & Rocha total & 2610 & 0,325 & 4,81 & 15,8 & 2052 & \pm 21 \\
\hline$S-70 A$ & Sienito & Biotita & 1563 & 7,59 & 13,90 & 16,6 & 411 & \pm 35 \\
\hline$S-88 A$ & Sienito & Anfibölio & 1056 & 1,030 & 3,91 & 5,1 & 766 & \pm 40 \\
\hline$S A L V-A$ & Diabásio & Rocha total & 2606 & 0,962 & 7,70 & 11,2 & 1366 & \pm 14 \\
\hline$S A L V-B$ & Diabāsio & $\begin{array}{l}\text { Rocha total } \\
\text { Plagioclásio }\end{array}$ & $\begin{array}{l}2578 \\
2581\end{array}$ & $\begin{array}{l}1,042 \\
1,436\end{array}$ & $\begin{array}{l}10,98 \\
11,06\end{array}$ & $\begin{array}{l}3,9 \\
4,0\end{array}$ & $\begin{array}{l}1653 \\
1330\end{array}$ & $\begin{array}{l} \pm 15 \\
\pm 14\end{array}$ \\
\hline SALV -5 & Granulito bāsico & Biotita & 2305 & 7,68 & 80,4 & 0,99 & 1678 & 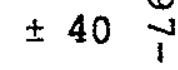 \\
\hline
\end{tabular}




\section{APÊNDICE 3 - continuação}

\begin{tabular}{|c|c|c|c|c|c|c|c|}
\hline NO CAMPO & ROCHA & MATERIAL & NO $\operatorname{LAB}(\mathrm{SPK})$ * & $8 \mathrm{~K} * *$ & $\begin{array}{c}\mathrm{Ar}^{40} \mathrm{rad} \operatorname{ccSTP} / \mathrm{g} \\
\times 10^{-5}\end{array}$ & $\therefore \mathrm{Ar}^{40} \mathrm{~atm}$ & 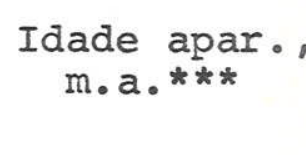 \\
\hline VI -28 & Gnaisse kinzigitico & Biotita & 2355 & 7,80 & 25,1 & 5,0 & $670 \pm 10$ \\
\hline$V I-62 A$ & Biot.Horn. gnaisse & Biotita & 2383 & 6,86 & 14,21 & 2,2 & $458 \pm 6$ \\
\hline$V I-103$ & Biotita gnaisse & Biotita & 2358 & 7,88 & 15,91 & 2,6 & $449 \pm$ \\
\hline$V I-176 \mathrm{~A}$ & Granulito básico & Biotita & 2360 & 7,67 & 17,19 & 11,7 & $492 \pm 10$ \\
\hline$V Q-412 B$ & Granulito básico & Anfibólio & 2311 & 1,735 & 1,610 & 1,79 & $1520 \pm 60$ \\
\hline $78 a$ & Gnaisse kinzigitico & Biotita & 1192 & 7,63 & 16,43 & 3,3 & $475 \pm 38$ \\
\hline $10 a-B-66$ & Granulito básico & Biotita. & 726 & 7,71 & 85,2 & 0,80 & $1705 \pm 48$ \\
\hline
\end{tabular}

* Todas as determinações foram efetuadas no CPGeo, São Paulo.

** Média de duas determinações.

$$
\therefore \mathrm{K}^{40} \mathrm{em} \mathrm{K}^{\text {tot }}=1,19 \times 10^{-2}
$$

*** Constantes do $\mathrm{K}^{40}$ empregadas: $\lambda_{\beta}=0,530 \times 10^{-9}$ ano $^{-1}$

$$
\lambda_{\mathrm{K}}=0,585 \times 10^{-10} \mathrm{ano}^{-1}
$$

$\nabla$ Padrão intralaboratório, utilizado para calibração de traçadores de argônio 38. $\nabla \nabla$ Média de 15 determinações. 